\title{
特殊鋼の分離抗張力と疲勞による耐久力に就て (II)
}

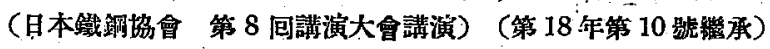

$$
\text { 高 瀨孝 次 }{ }^{1} \text { ) }
$$

(第 4 章)

\section{第 2 節街摮脆性}

脆性を最む良く代表的て示するのとして國際的

て定められてるるのは衝敬試驗による衝繁值であ るが、本試驗を材料の規格に迄为課する樣になう たのは僅か 10-15 年前化過ざず。主として航空 機材料の探用されそ時に重視されたものである。

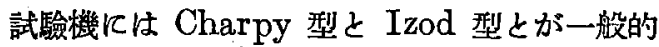

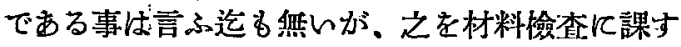
る事の是非と、之を如何程几重視するか例へば破 損金質の調查の結果衝䇣値の低かつた事に直接間 接に故障刃は破損流影を有したか否かの原因た るゃ頗る疑問の存する處であつて、今之等の點に 關して筆者の今日迄に得られたる試驗の結果貒 して論及せんてするるのである。

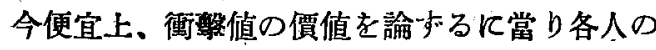
立場を明にする必要がある。

1. 村料裂造省

2. 村料使用又柱取扱者

材料製造者は材料の改善を目的とする第め換言 すれ代良き材料老得る篇め几衝慗值を如何に見做 すか、他の一方で性材料使用火際し强度の完全な る事即ら如何なる負荷狀態でる安心し得る事換言 するなら代耐久性充分るる事を重視与るならば、

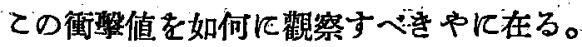
唯衝撃值は極的て微妙の性質と左右すべ條件

陸軍航然本部技衙部
が热數に在る。例人げ次の通りである。

1. 試 驗 機

2. 試 驗 片

3. 試驗片の溝

4. 試驗片の踜作

5. 材料の鎦造、銈鍊の程度. 寸法

6. 材料の燒入、燒戻及冾印速度、殊飞燒戻溫 度と冷却時間には最る大きな關係がある。

7: 材料から試驗㸝の探取要項

殊に大なる材料では內外部に於て著しく差あ り又は縱箱の方向飞切出す事によつて大差が ある。

之等樣くの條件で支配されてるる故沉将料の基 給者師ち製造者は檢查方法如何に基く成績の差に 上る不合格の题念を生交る事が多く、殊儿燒戻溫

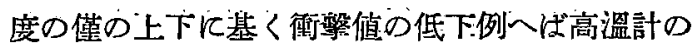

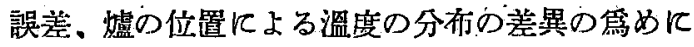

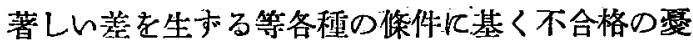
がある。

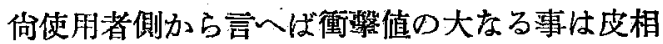
的飞觀察するならば折損し鹳的と制斷さるっかる 知机ないが、事賽は之に反し實際疲勞破斷に上る

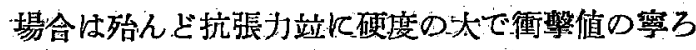

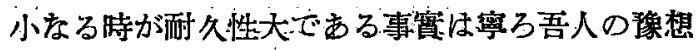

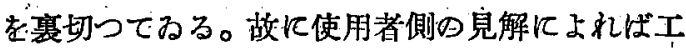
作上の可能性有れ斿成るべく抗張力高く若干の街 榽值を檥牲にする多可であると言ふ結果となる。 
即ち衝整値を高める䉆めに餘り燒戻溫度を高める 事は危险である。

併し材料の品質の上からは衝撃值の高い事は低 レより（抗張力同程度として）名品質良好の狀態 にあるものと考へられるが夫より察ろ次の㥞な副 結果を吾人に與へてくれる。

1. 破面の景況で燒戾の齋一か材料の齊一かを 檢す

2. 破面に生する瘷により材料の內部に潜在す る pinhole 等を檢出出桃る。

3，破面の景況で材料を見分けられるか又は組 織、溫度の概略も知る事が出來る。

故に之等重要指針を興へる試驗と見れば檢查項 目に本試驗を課する事は反對の要㫮く、唯之が筫 用上價值に就ては見解を改め使用者は餘りに重視 せざるを寗る安全と認めらる。假りに砲身鋼や防 楯鋼の㮏な 1 回に大きな衝整を受ける場合注別と するも多くの繰返震動的荷重を受ける場合は衝撃 值を低下するる立分能力を發揮してるる實例が多 no

本論文には主に Charpy 型試驗機に依つを試 驗成樍を基礎として其の性質を出束る丈け明膫に し、脆性の本質と更に分蜼抗張力よの關係を探究 する事とする。

其 1: 各種鋼以熱處理による衝娐值

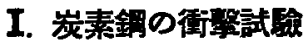

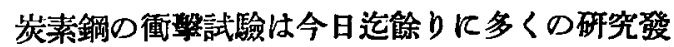
表あつて、ていに別に記すととを省くる今一例を 取つて牛硬鋼の燒鉝溫度の變化上燒入後燒戻溫度

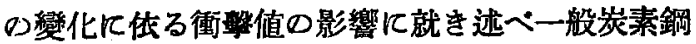
の脆性に就て說述するてよ」する。分析成分は次 の通りである。

$\begin{array}{ccccc}C & S i & M n & P & S \\ 0.37 & 0.31 & 0.47 & 0.013 & 0.010\end{array}$

この結果恃附圖 No. 117 に記してある。燒鈋 及燒戻溫度別の場合共に $700^{\circ} \mathrm{C}$ 几於行るものは 衝擊值最大である、郎ち $A_{1}$ 数態點附近で冷却し たるのは所謂ニセコ處理と同樣に球状 Pearlite （Sorbite からの變化）状にあることは質を最粘

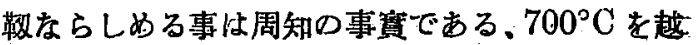
せば急に脆性を增大し以上大なる變化を件梳な

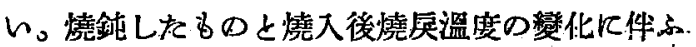

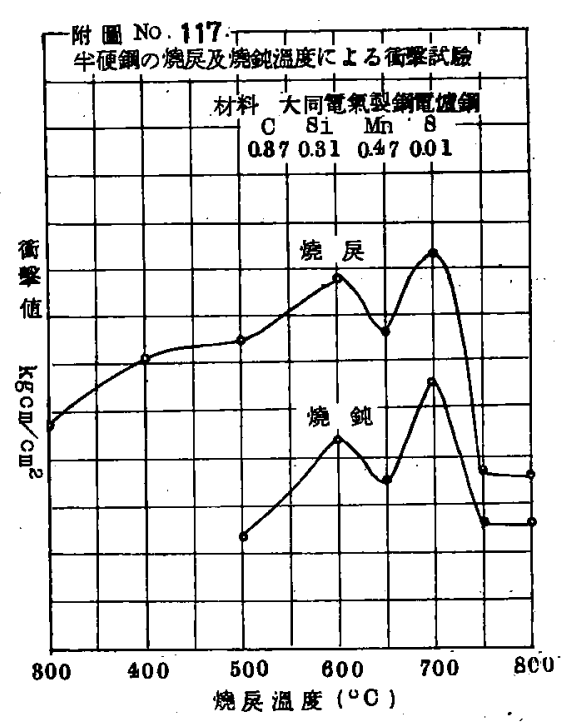

衝整值 の比较: をなせ ば後者 は著し く大き い事は 曲線で 知 5 れるが 盢度に 上る變 化曲線は同樣であつて何れる $700^{\circ} \mathrm{C}$ て最大であ るのはこの點では完全な Sorbite: となりそれ以 上店 Pearlite に分解する篇めであつて Pearlite Stateでは衝整力は著しく低い。師ち脆化するの である。憢鈍の場合では $500^{\circ} \mathrm{C}$ 附近と $750^{\circ} \mathrm{C}$. 以上の場合赇共に同一衝繁值に在るは何れ Pearlite-State K在る事が知れる。

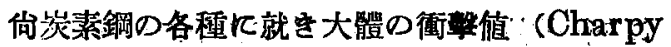
式）を得るために燒鈍、燒入、燒戾狀熊を比較し て見る。 


\begin{tabular}{|c|c|c|c|c|}
\hline \multirow{3}{*}{ 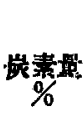 } & \multicolumn{2}{|c|}{ 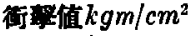 } & \multirow{2}{*}{ 熱 處 } & \multirow[b]{2}{*}{ 理 } \\
\hline & & 燒 & & \\
\hline & 靚釷 & & 蛙距 & 燒入 \\
\hline 0.2 & $9 \cdot 5$ & $10^{\circ} 0$ & 820 (灰) & \\
\hline 04 & 5.4 & 70 & 800 (灰) & $50-$ \\
\hline 77 & 26 & $4: 3$ & 780 (作) & \\
\hline
\end{tabular}

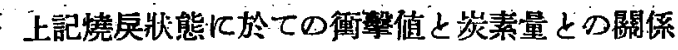
武柱大體次の稼に示す事を得。

$\therefore \quad$ 衝慗值 $\rho\left(\mathrm{kgm} / \mathrm{cm}^{2}\right)=\frac{28}{C}-1 \quad C$ 岁麦量

一般に炭素鋼の脆性は $F e_{3} C$ の遊離に歸因する と解釋されてあるか $C$ の極めてそしんアームコ 臷の場合にも著しい脆性を呈する處理法がある。 石澤氏（三菱航空機會社研究報告第 275 號）は アームコ鐵に就して下記の樣な熱處理の差により 衝擊値に極めて大きい差のある事を報じてるる。

\begin{tabular}{|c|c|}
\hline 理 & 衝稘值 $\mathrm{kgm} / \mathrm{cm}^{2}$ \\
\hline 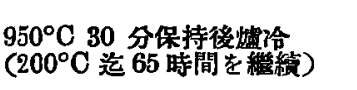 & $\left.\begin{array}{l}7.58 \\
4.80 \\
5.40\end{array}\right\} 5.93$ \\
\hline $\begin{array}{l}950^{\circ} \mathrm{C} 30 \text { 分保持後 } 900^{\circ} \mathrm{C} \text { 迄 } \\
60 \text { 分 } 90^{\circ} \mathrm{C} \text { K } 60 \text { 分保持水冷 }\end{array}$ & $\left.\begin{array}{l}0.44 \\
0.44 \\
0.44\end{array}\right\} \quad 0.44$ \\
\hline $\begin{array}{l}950^{\circ} \mathrm{C} 30 \text { 分保持後水冷 } \\
900^{\circ} \mathrm{C} 60 \text { 分保持後水冾 }\end{array}$ & $\left.\begin{array}{l}35 \cdot 38 \\
34: 75 \\
35 \cdot 00\end{array}\right\} 35$ \\
\hline
\end{tabular}

上記試驗の結果最均齊で柔軟な質を得るには $900^{\circ} \mathrm{C}$ 下加熱後 $700^{\circ} \mathrm{C}$ 迄徐冷し後水中急冷した るので單に $700^{\circ} \mathrm{C}$ に加熱徐泠したるのる稍脆い。 之を要するに $700^{\circ} \mathrm{C}$ に於ては Sorbitic の最 粘鞂性の大なる狀態にある事を知りての事實は R. H. Greaves \& J. A. Jones (Woolwich) の實驗した高溫及低溫狀態に於ける衝繋試驗の結 果上も符號してるる(附圆 No.118 及 No.119)。

藤田氏（鐵と鋼第十一七年第十號）は燒鈍溫度と 冷却速度上によつて燒戻脆性と同様燒鈍脆性のあ る事を指摘した。

之等は何れる鐵中の $F_{e} C$ の存在によつて之の

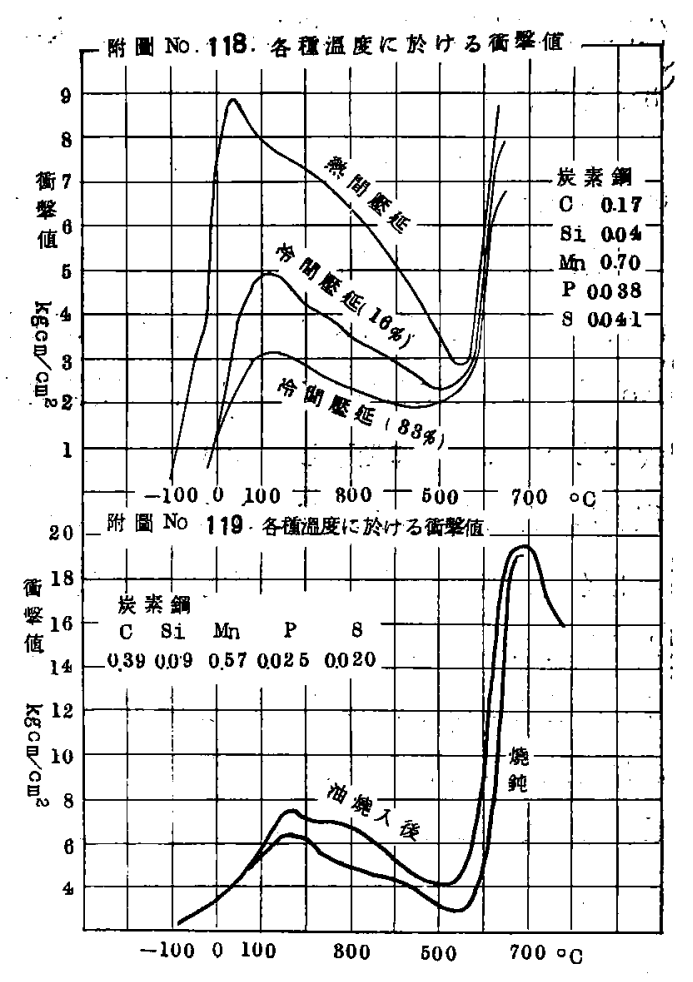

分離程度に比例するてと變態點以上の高溫上り冷 却の場合は Grain Growthの現象によつて脆性 を增すことを述でた。

筆者は衝擊試驗による脆性は溝付影響を有する 事と fiue Brittleness (細粒脆性) と coarce Brittleness (粗粒脆性) とが $\mathbf{A}_{1}$ 秒態點上下K 起り $A_{1}$ より僅に以下の溫度に於りる燒戾状態郎 ち Sorbitic State にあるるのは蓜擊力に於て勝. つてるてる。他の機械的性質上は決して望ましん． 㕱態では䉆い事を指摘したいのである。

而して脆性俚試驗片の形狀と溝の形狀にも支配， され組織上は Slip 又は glide し易き狀態郎ち 變形變位を惹起し易き材料には起らないてをを示 すてとさする。

\section{II. $86 \mathrm{~kg} \mathrm{Ni}-\mathrm{Cr}$ 錭}

本鋼は今日迄多くの設動機其の他の機械部品に。 
一使はれを强力鋼であつて其主要成分は大體次の通 りである。

$\begin{array}{lllll}C & S i & M n & N i & C r\end{array}$

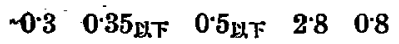

本鋼の鍜造の盘から各棰

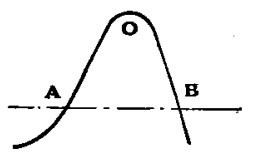

溫度で燒鈍し宾中冾却による衝般力の狀態仙附圖

No.120に示してある。 $650^{\circ} \mathrm{C}$ に於ては最衙整值 大で $750^{\circ} \mathrm{C}$ で急に低下し $800^{\circ} \mathrm{C}$ 附近で若干恢 復する結果よなる。之で見てる $500^{\circ} \mathrm{C}$ 以下では 著しく脆いが $650^{\circ} \mathrm{C}$ 以上の溫度では低溫の脆性 とは如何なる性質上の相違があるかは研究を要 す。唯燒鈍の影響は元の錪造肤態が Pearliteな れば變態點の上下に論なく何れる Coarce Brittleness であつて Pearlíte 'の墢涬程度によつて
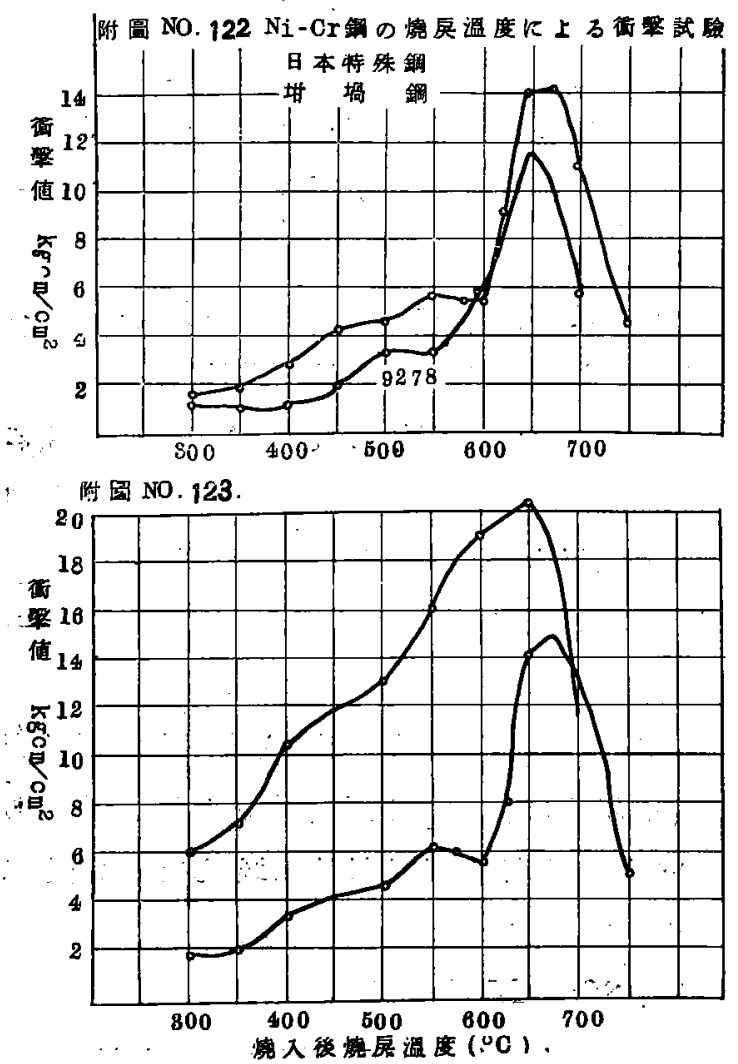

衙盤值に差を生する。

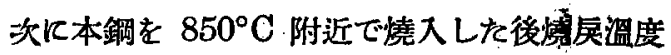
を變化する時も大體同樣に衝整値の變化は現れる がその景況は附圖 No.121 乃至 No.125 亿示し てある。てれ等㭡總て同種の $N i-C r$ 鋼であるが 曲線はすへて若千の相違を見る。唯或種のるのは $550^{\circ} \mathrm{C}$ を境界として之以下の燒戻盜度で衝揧値 の至つて低き種類と殆んど始めから直線的に 650 ${ }^{\circ} \mathrm{C}$ 迄上昇するものとある。前者の様な $\mathrm{Ni}-\mathrm{Cr}$ 鋼は規格には合格せざるもの多くこの種のものは 將して性能の不良なるbのか否か研究の要すり。

從來の經驗上 $C$ の低く且 $C r$ 狳方高加方さる るのはからる現稚を呈すること少きるの小梯です るが斯るるのは一方抗張力硬度低く所胵の强さを

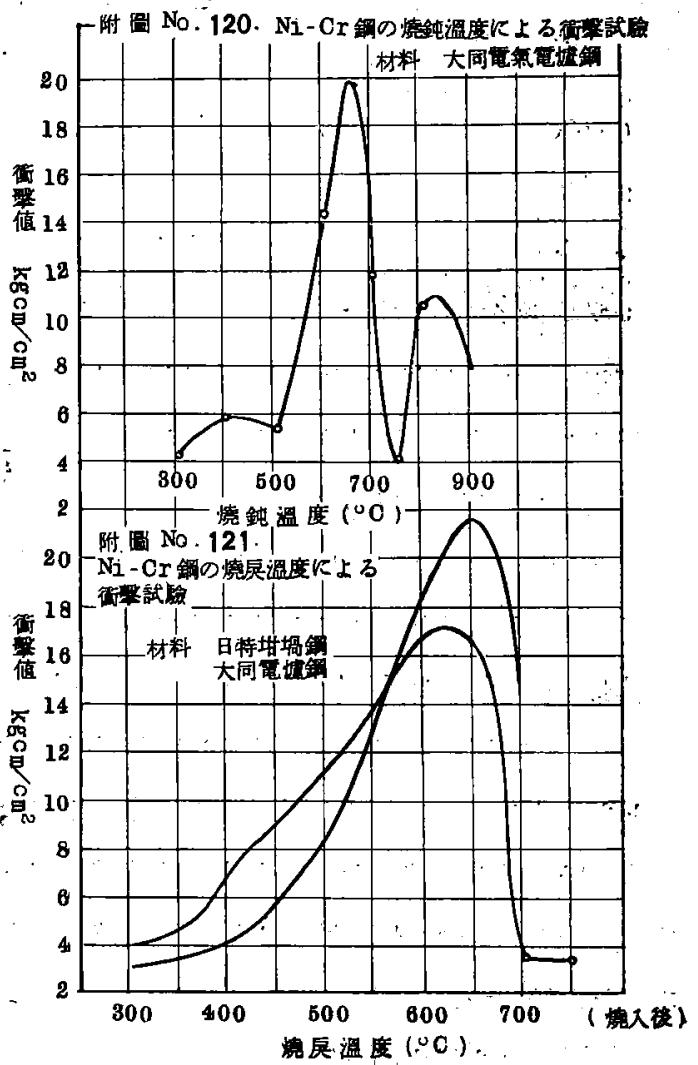




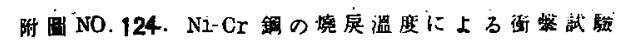

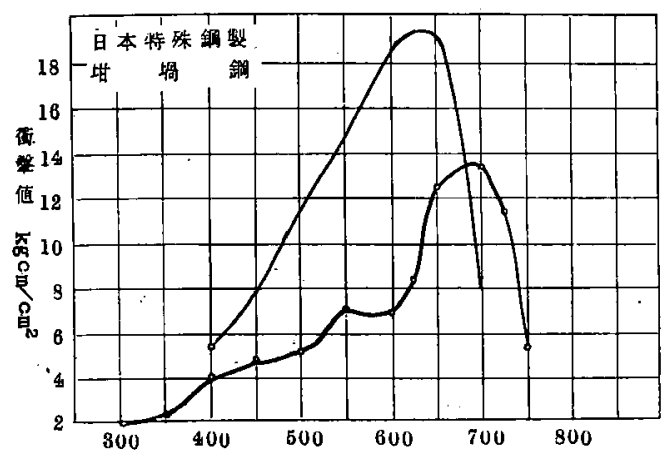

附国 NO. 125.

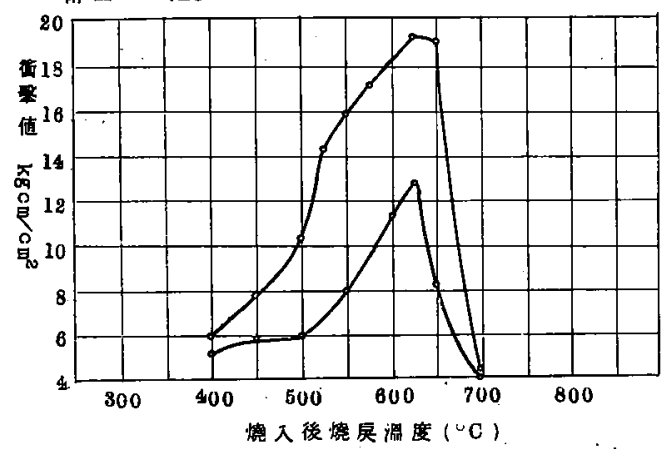

得難い結果となり返つて危險性を伴ふものではな 加5か。

燒㞔温度の變化によつて衝整値に極めて犬きな 差を生ずる事は附圖曲線で明で西るが、今假に A と $\mathrm{B}$ との 2 點の脆性を比較する事とすれば、衝 霓值汒同一であるからら脆性は同一であると云へる。 が、A 點江組織上から云へば Sorbite 化せんと する點であるのに B 點は Sorbite が分解して Pearlite 化せんとする狀態郎 $F e_{3} C$ の分離せん とすることを示し、衙擊值仗同一であり年らBrittleness を異にしてねる。A 點け B 點より 抗張力、硬度、耐久限界等著しく高く 0 點より応 は固熔體の脆性上る見做さる飞對し右方は介在物 として $\mathrm{Fe}_{3} \mathrm{C}$ の游離に基く脆性を示し。從つて $\mathrm{A}$ の方は Grain は平滑となつて破断し、B は粒狀 光濹を呈する事となる。前者を細粒脆性（fine
Brittleness) よすれば後者は組粒脆性（CoarceBrittleness) よ稱せられる。Martensite 几於け る脆性は Slip 又はDeformation を件はなん、 互の結果の亡りを障げ破斷する。故に之と同様に 呅めて細微なる $F e . C$ (Cementite) ゃ，WC (Tungstite) の組織にあるるのる Slip 又は Deformation を障げる䉆に細粒脆性となる。

\section{III. $\mathrm{Ni}-\mathrm{Cr}$ 表面硬化用鋼}

$C$ の少い $\mathrm{Ni}-\mathrm{Cr}$ 銅を $850^{\circ} \mathrm{C}$. 油燒入後燒戻 溫度別に衡整檤の變化を試驗した結果は附圖No126 に示してある。

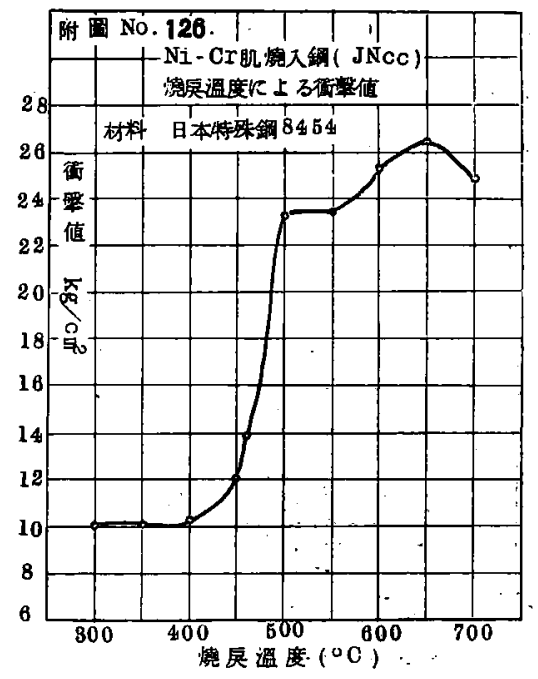

燒戻溫度 $400^{\circ} \mathrm{C}$ 迄は衝般值低く大差はないか $500^{\circ} \mathrm{C}$ ๖急に上昇し夫れ以上再び大差なく650 ${ }^{\circ} \mathrm{C}$ で最大となり、700 $\mathrm{C}$ で僅に低下するに止る。 此變化は $C$ が $0.12 \%$ 程度で極めて少く $\mathrm{Fe}_{3} \mathrm{C}^{+}$ の游離が $650^{\circ} \mathrm{C}$ 以上燒杘の場合にも少く粗粒脆 性を呈し得ないるのと解釋される。

\section{IV. $100 \mathrm{~kg}$ Nï-Cr 龬}

本鋼の成分は次の通りであつて熱處理は燒入 $830^{\circ} \mathrm{C}$ (油中)の後燒戻老變更した。 


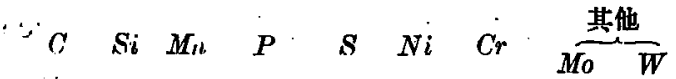

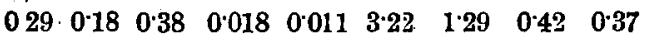

燒杘溫度別に求めた衝整做及硬度の變化は次の通 りである。

\begin{tabular}{|c|c|c|c|c|}
\hline 燒愿溫度 & 衙繁値 & $\left(\mathrm{kgm} / \mathrm{cm}^{2}\right)$ & $\begin{array}{c}\text { プリネル } \\
\text { 硬 }\end{array}$ & $\begin{array}{c}\text { 口゙クウ } \\
\text { C硬度 }\end{array}$ \\
\hline 300 & $\left.\begin{array}{l}65 \\
64\end{array}\right\}$ & 6.45 & 430 & $45 \cdot 4$ \\
\hline-350 & $\left.\begin{array}{l}56 \\
575\end{array}\right\}$ & $5 \cdot 67$ & 415 & $42 \cdot 9$ \\
\hline$\cdot 400$ & $\begin{array}{l}5 \cdot 47 \\
6 \cdot 5\end{array}$ & 600 & 380 & $40 \cdot 97$ \\
\hline 450 & $\left.\begin{array}{l}6 \cdot 57 \\
6 \cdot 17\end{array}\right\}$ & $6 \cdot 37$ & 375 & $40 \cdot 90$ \\
\hline 500 & $\left.\begin{array}{l}6.97 \\
6.97\end{array}\right\}$ & 697 & 365 & $39 \cdot 9$ \\
\hline 550 & $\left.\begin{array}{l}11 \cdot 24\} \\
11 \cdot 63\end{array}\right\}$ & $11 \cdot 44$ & 340 & $39 \cdot 1$ \\
\hline 600 & $\begin{array}{l}15 \cdot 85 \\
14 \cdot 68\end{array}$ & $15 \cdot 27$ & 295 & 3283 \\
\hline 650 & $\left.\begin{array}{l}14 \cdot 04 \\
14 \cdot 06\end{array}\right\}$ & 1405 & 270 & $29 \cdot 8$ \\
\hline 700 & $\left.\begin{array}{l}6.07 \\
1.07\end{array}\right\}$ & 6.07 & 430 & $47 \cdot 9$ \\
\hline 750 & $\left.\begin{array}{l}5.54 \\
9 \cdot 37\end{array}\right)$ & $7 \cdot 46$ & 375 & 29.5 \\
\hline
\end{tabular}

性線に示せ代附圖 No.127 の通りである。ての結
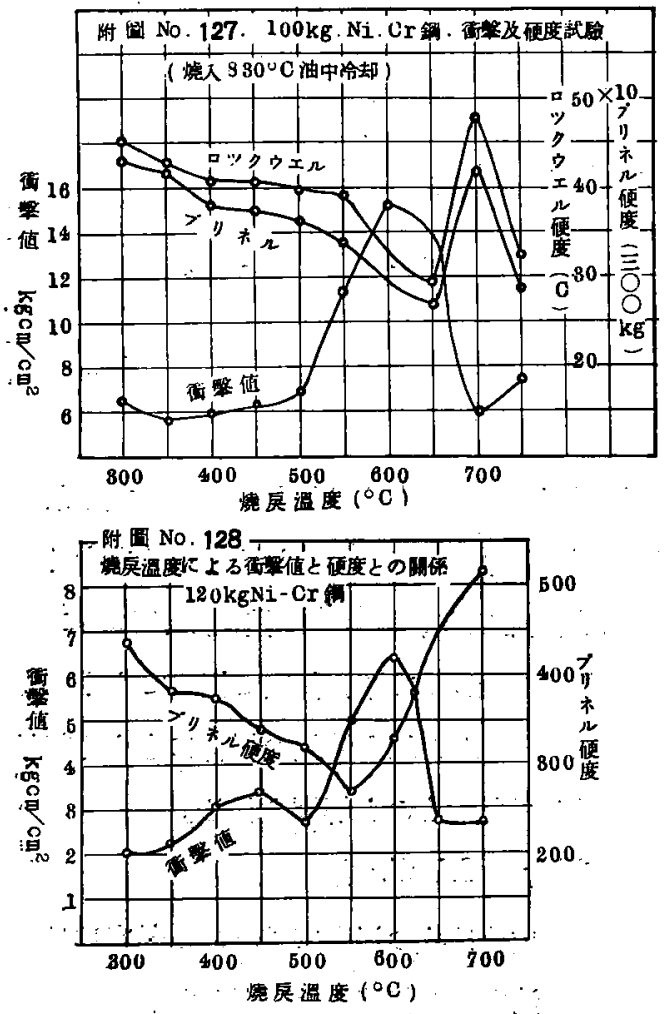

果に依れば衝擊值は $600^{\circ} \mathrm{C}$ で最大で硬度は 650 ${ }^{\circ} \mathrm{C}$ が最低である。

\section{V. $120 \mathrm{~kg} \mathrm{Ni}-\mathrm{Cr}$ 銅}

本鋼の成分壮次の通りであつて熱處理に燒入 $850^{\circ} \mathrm{C}$ の後燒杘を次の如く變更した。

$\begin{array}{cccccccc} & C & S i & M n & P & S & N i & C r \\ 1 & 0.43 & 0.28 & 0.34 & 0.020 & 0010 & 373 & 1 \cdot 18 \\ 2 & 0.31 & 0.31 & 0.34 & 0.022 & 0020 & 3.70 & 1.01\end{array}$

燒戻溫度別に求めた衝酷值及硬度の變化恃次の通 である。

\begin{tabular}{|c|c|c|}
\hline 燒庆盢度 ${ }^{\circ} \mathrm{C}$ & 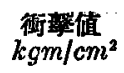 & $\begin{array}{c}\text { ブリネル } \\
\text { 硬 度 }\end{array}$ \\
\hline $\begin{array}{l}300 \\
350 \\
400\end{array}$ & $\begin{array}{l}2 \cdot 0 \\
2 \cdot 26 \\
3 \cdot 09\end{array}$ & $\begin{array}{l}436 \\
\mathbf{3 8 1} \\
\mathbf{3 7 7}\end{array}$ \\
\hline $\begin{array}{l}450 \\
500 \\
550\end{array}$ & $\begin{array}{l}3.42 \\
273 \\
4 \cdot 93\end{array}$ & $\begin{array}{l}339 \\
319 \\
270\end{array}$ \\
\hline $\begin{array}{l}600 \\
650 \\
700\end{array}$ & $\begin{array}{l}6.41 \\
277 \\
275\end{array}$ & $\begin{array}{l}328 \\
457 \\
512\end{array}$ \\
\hline
\end{tabular}

曲線に示せば附圖 No.129 の通りである。ての結 果に侤れば衝撃值は $600 \mathrm{C}$ で最大でブリネル硬 度は $550^{\circ} \mathrm{C}$ が最低である。

\section{VI. $\mathrm{Ni}-\mathrm{Cr}-\mathrm{W}$ 銅}

本鋼の成分は次の通りであつて熱處理は燒入 $850^{\circ} \mathrm{C}$ 空中冷却の媵燒戻を次の様沉變更した。

$\begin{array}{lllllllll}C & \text { Si } & M n & P & S & \mathrm{Ni} & \mathrm{Cr} & \mathrm{W}\end{array}$ $\begin{array}{llllllll}0.22 & 0.16 & 0.40 & 0.012 & 0.011 & 4.00 & 1.37 & 0.75\end{array}$

燒杘溫度别飞求好を衝整值度硬度の變化は次の 通りである。

\begin{tabular}{|c|c|c|c|c|}
\hline 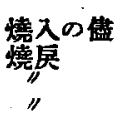 & $\begin{array}{l}100 \\
150 \\
200\end{array}$ & $\begin{array}{l}8 \cdot 11 \\
799 \\
8 \cdot 55 \\
7 \cdot 88\end{array}$ & $\begin{array}{l}38 \cdot 5 \\
385 \cdot 0 \\
390 \cdot 0 \\
388 \cdot 5\end{array}$ & $\begin{array}{l}39 \cdot 3 \\
39 \cdot 6 \\
39 \cdot 7 \\
39 \cdot 8\end{array}$ \\
\hline ." & $\begin{array}{l}250 \\
300 \\
350 \\
400\end{array}$ & \begin{tabular}{r}
797 \\
$-\quad 785$ \\
\hdashline$\quad 734$ \\
$\quad 748$
\end{tabular} & $\begin{array}{r}383.5 \\
r 376.5 \\
-3850 \\
3710\end{array}$ & $\begin{array}{l}40 \cdot 0 \\
39 \cdot 1 \\
39 \cdot 5 \\
38 \cdot 7\end{array}$ \\
\hline "" & $\begin{array}{l}450 \\
500 \\
550 \\
600\end{array}$ & $\begin{array}{r}8 \cdot 22 \\
8 \cdot 67 \\
10 \cdot 14 \\
16 \cdot 30\end{array}$ & $\begin{array}{l}365.5 \\
355.0 \\
338.5 \\
286.5\end{array}$ & $\begin{array}{l}37 \cdot 7 \\
36 \cdot 5 \\
35 \cdot 8 \\
297\end{array}$ \\
\hline
\end{tabular}




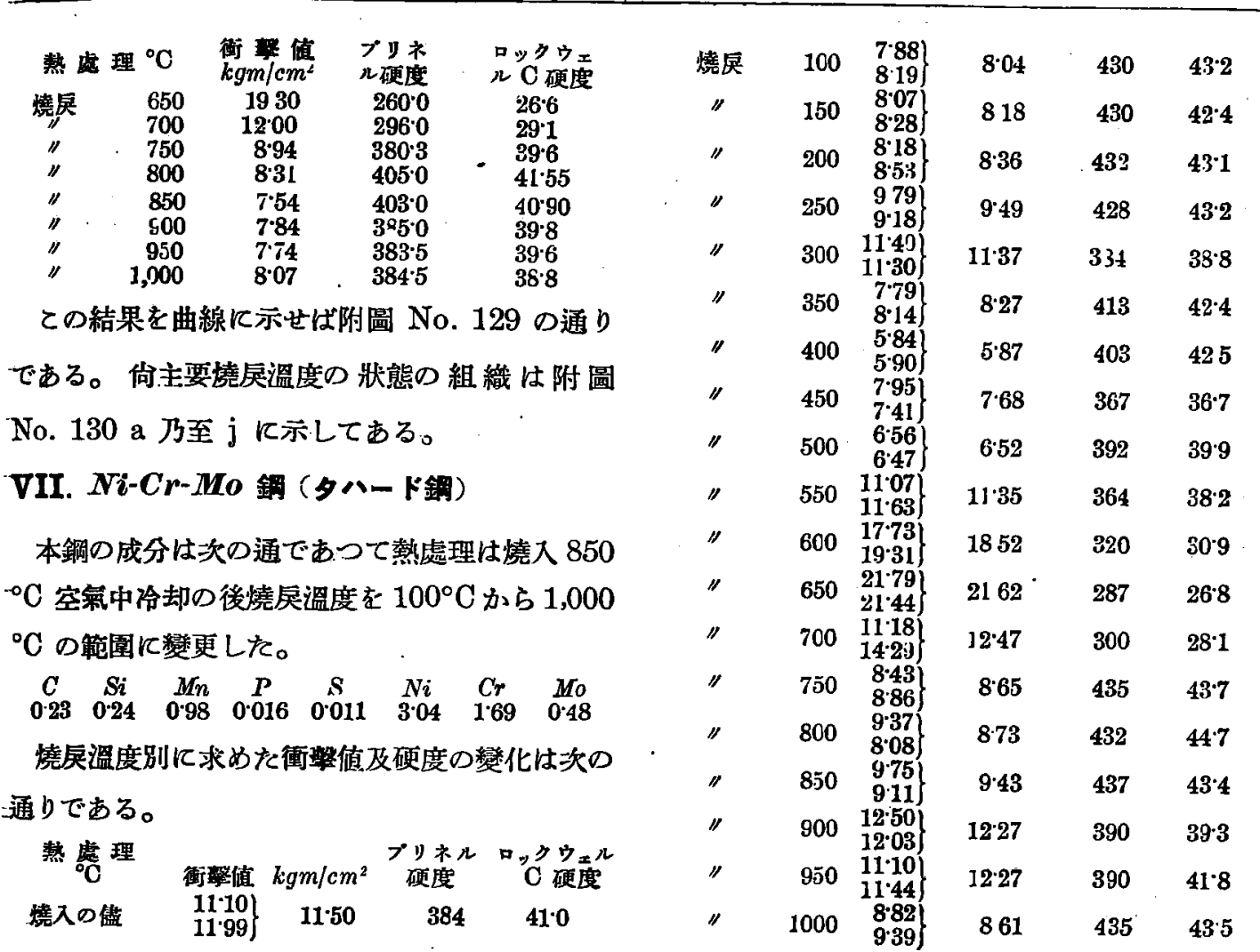

附圖 NO. 129. B MW 曲軸鋼乙 (Ni. CrW.) 衝繁及硬度試驗

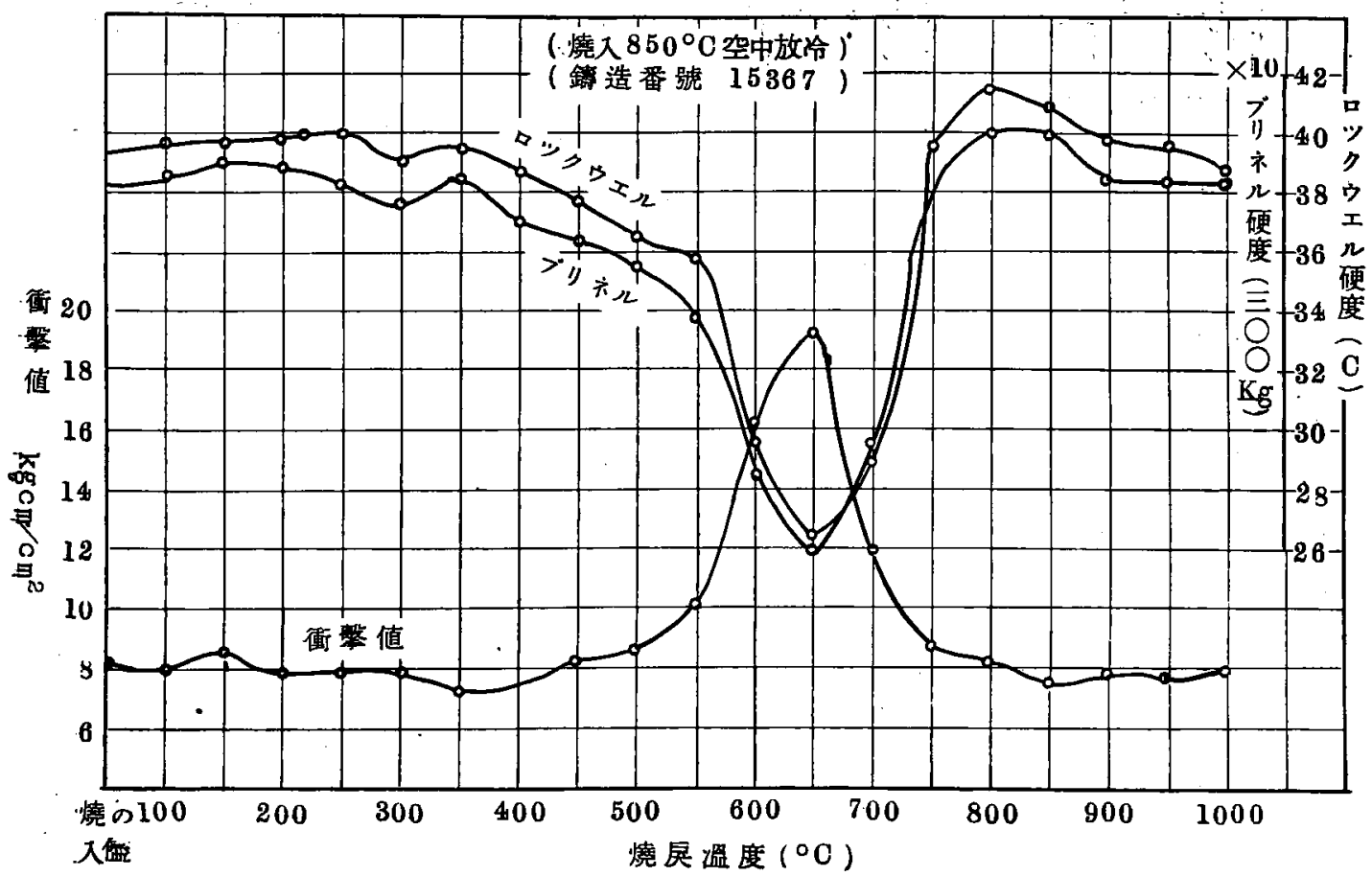




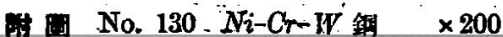

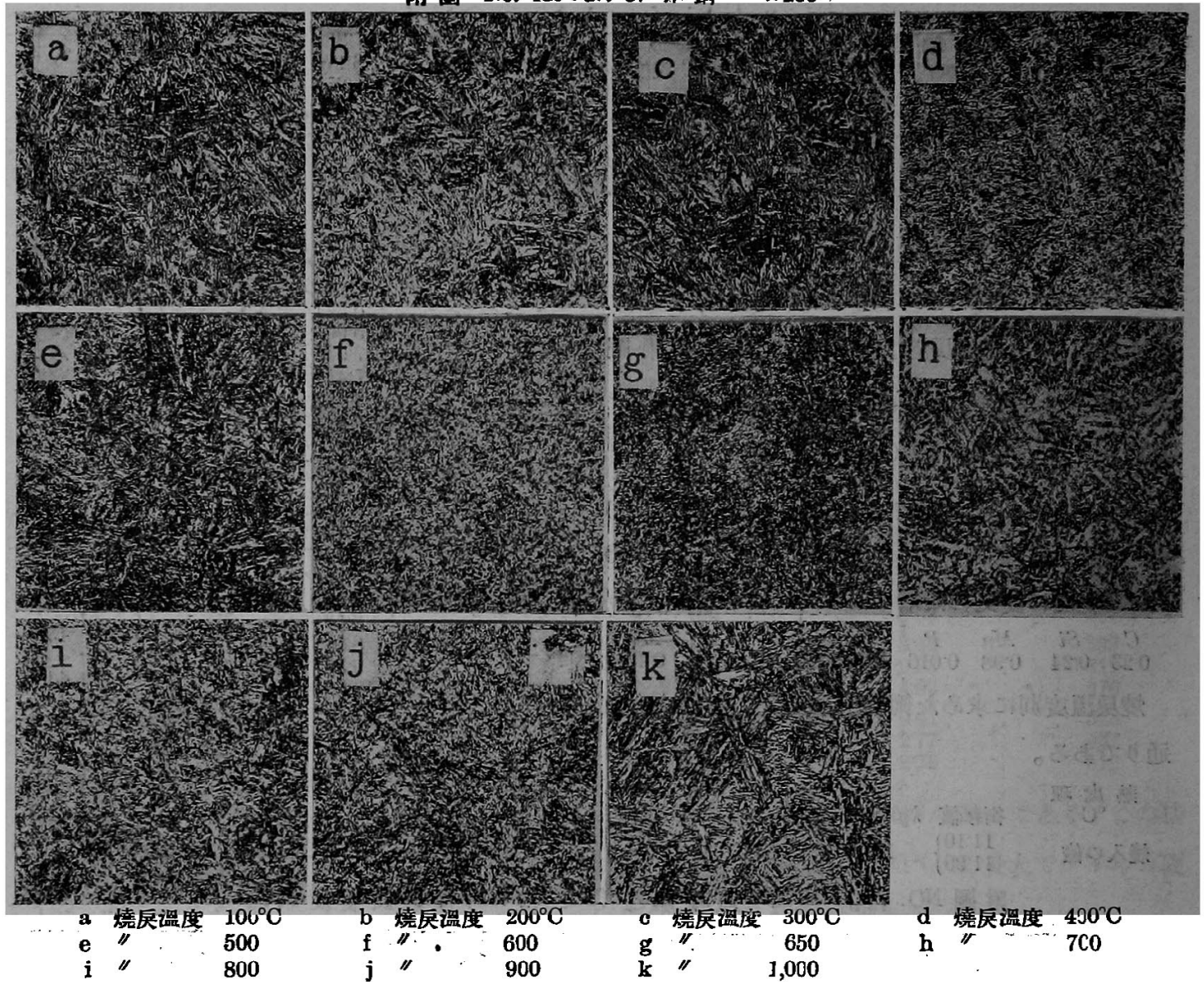

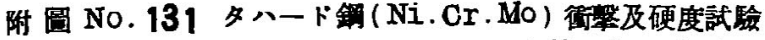

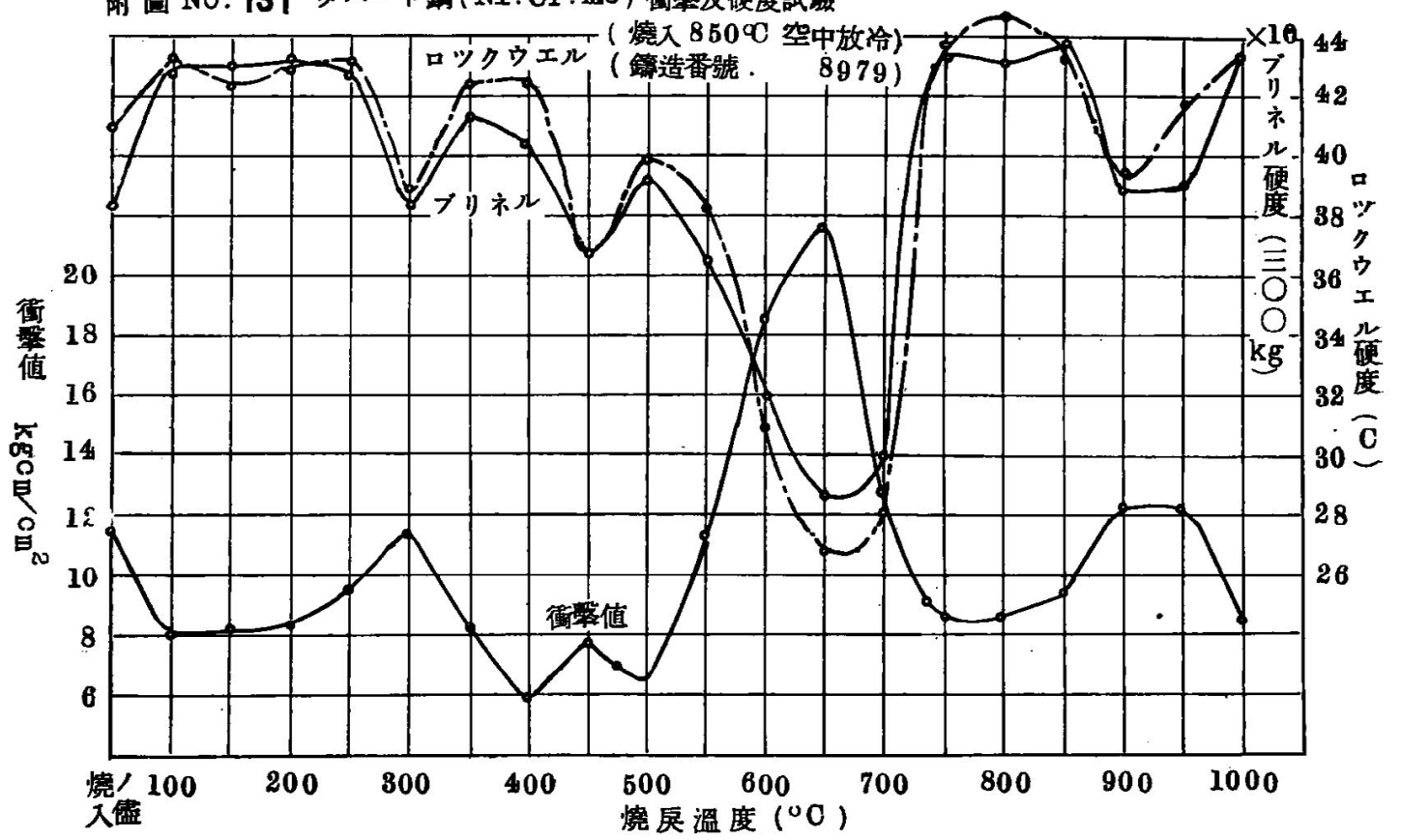




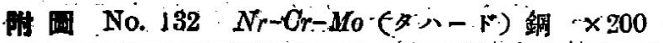

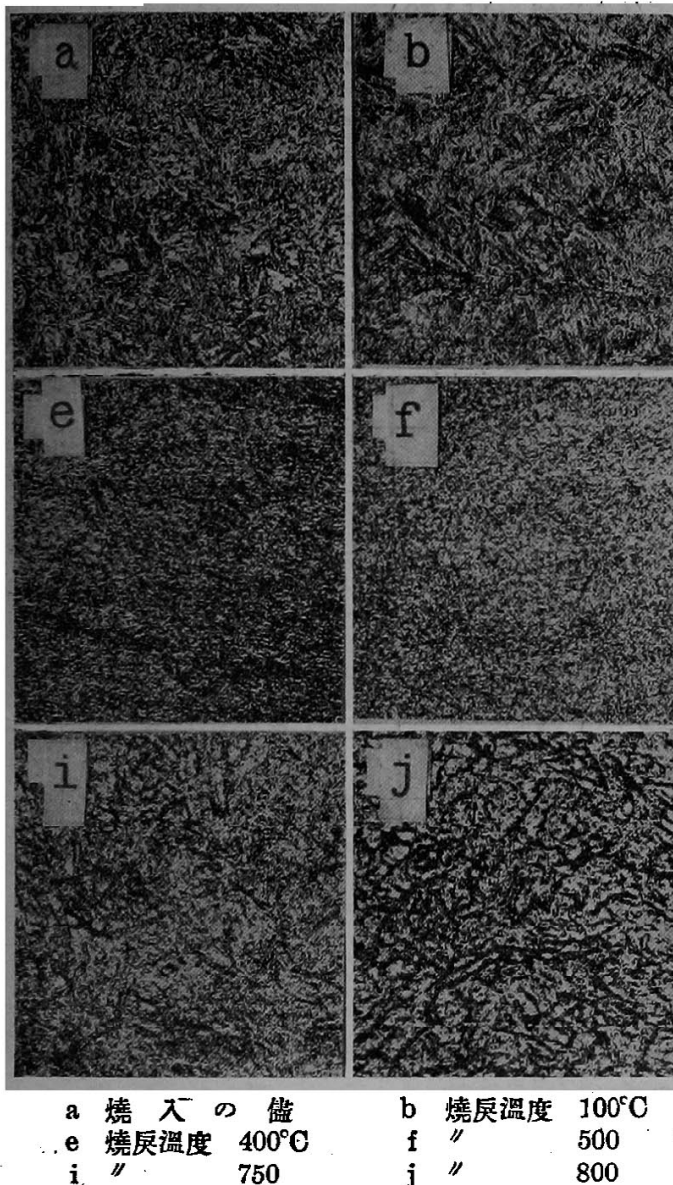

この結果を曲線に示せば附圖 No. 131 の通り である。份主要燒戻狀態の組織は附圖 No. 132a 乃至 1 に示してある。

\section{VIII. $C r-\nabla a$ 銅}

・本鋼の成分は次の通りである。爇處理は燒入 $850^{\circ} \mathrm{C}$ 油中冷却として燒戻は $100^{\circ} \mathrm{C}^{-}$乃至 1,000 ${ }^{\circ} \mathrm{C}$ の範圍に變更した。

$\begin{array}{ccccccc}C & S i & M n & P & S & C r & V u \\ 0.37 & 0.26 & 0.49 & 0.010 & 0.030 & 1-15 & 0.25\end{array}$ 燒㞔溫度別に求めた衝唯傎及硬度の變化は次 の通りである。

\begin{tabular}{|c|c|c|}
\hline 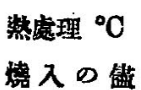 & $\begin{array}{c}\text { 衝缼/值 } \\
\mathrm{kg} / \mathrm{gm} / \mathrm{cm}^{2} \\
4: 10\end{array}$ & $\begin{array}{c}\text { プリネル } \\
\text { 硬 } \\
{ }_{370}\end{array}$ \\
\hline
\end{tabular}
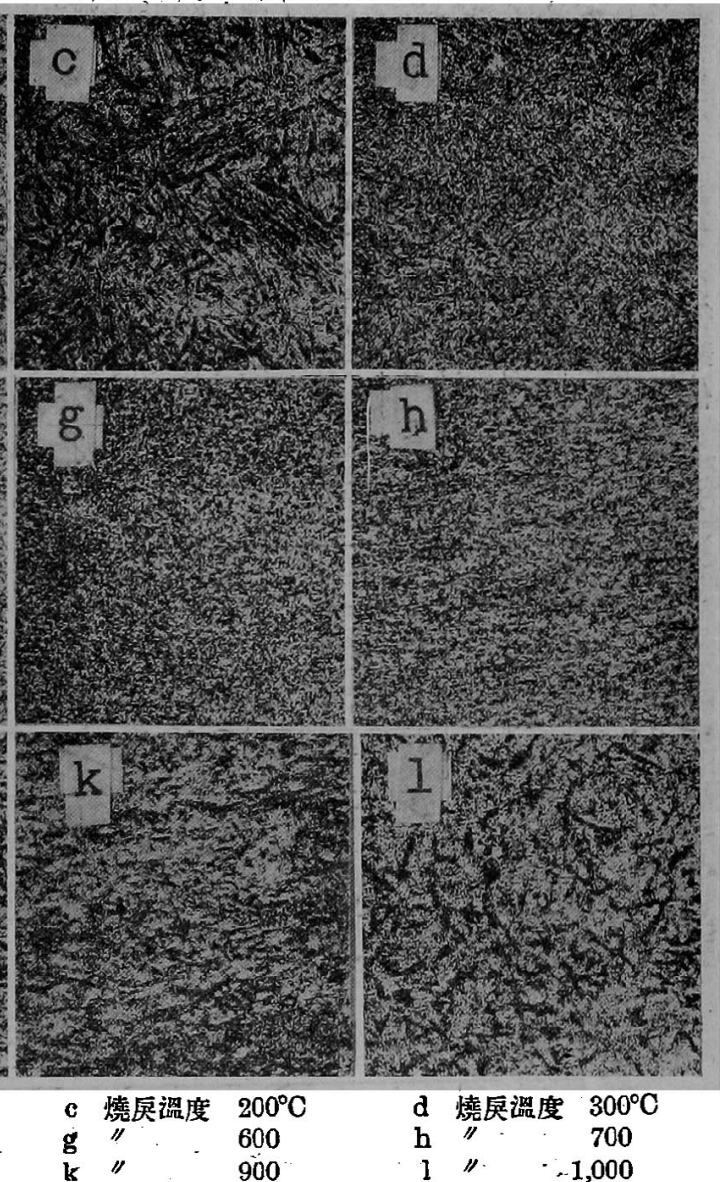

\begin{tabular}{|c|c|c|c|c|}
\hline & ${ }^{\circ} \mathrm{C}$ & $\mathrm{kg} / \mathrm{cm} \mathrm{cm}^{2}$ & プリネル & ロッウウウェル \\
\hline 范少 & 100 & $3 \cdot 77$ & 387 & 434 \\
\hline " & 150 & $\begin{array}{l}4.28 \\
4.54\end{array}$ & $\begin{array}{l}358 \\
364\end{array}$ & $\begin{array}{l}38 \cdot 2 \\
49 \cdot 4\end{array}$ \\
\hline " & 250 & 5.82 & 395 & 44.8 \\
\hline " & 300 & $5 \cdot 05$ & 379 & 42.4 \\
\hline " & 350 & $4 \cdot 19$ & 358 & $40 \cdot 5$ \\
\hline " & 400 & $6 \cdot 10$ & 340 & $39 \cdot 2$ \\
\hline " & 450 & 6.60 & 325 & 389 \\
\hline 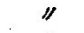 & 500 & $7 \cdot 38$ & 332 & $37 \cdot 7$ \\
\hline " & 550 & 797 & 311 & $34 \cdot 6$ \\
\hline " & 600 & 8.34 & 277 & $32 \cdot 8$ \\
\hline " & $\begin{array}{l}650 \\
700\end{array}$ & $\begin{array}{l}15 \cdot 65 \\
19 \cdot 89\end{array}$ & $\begin{array}{l}257 \\
210\end{array}$ & $\begin{array}{l}29 \cdot 8 \\
23 \cdot 0\end{array}$ \\
\hline "I. & 750 & $25 \cdot 60$ & 183 & 20.3 \\
\hline & 80 & 20.27 & 179 & $17 \cdot 8$ \\
\hline " & 850 & $15 \cdot 92$ & 187 & $18 \cdot 6$ \\
\hline : & 90 & 8.2 & 234 & \\
\hline I & & 37 & 309 & 325 \\
\hline $\mathbb{1}$ & (1) & $4: 39$ & 296 & \\
\hline
\end{tabular}

この結果を曲線に示せば附圖 No. 133 の通り である。尚主要燒戾狀態の組織注附闻 No.134a 


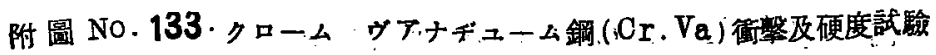

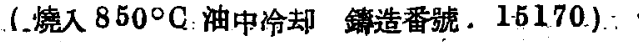

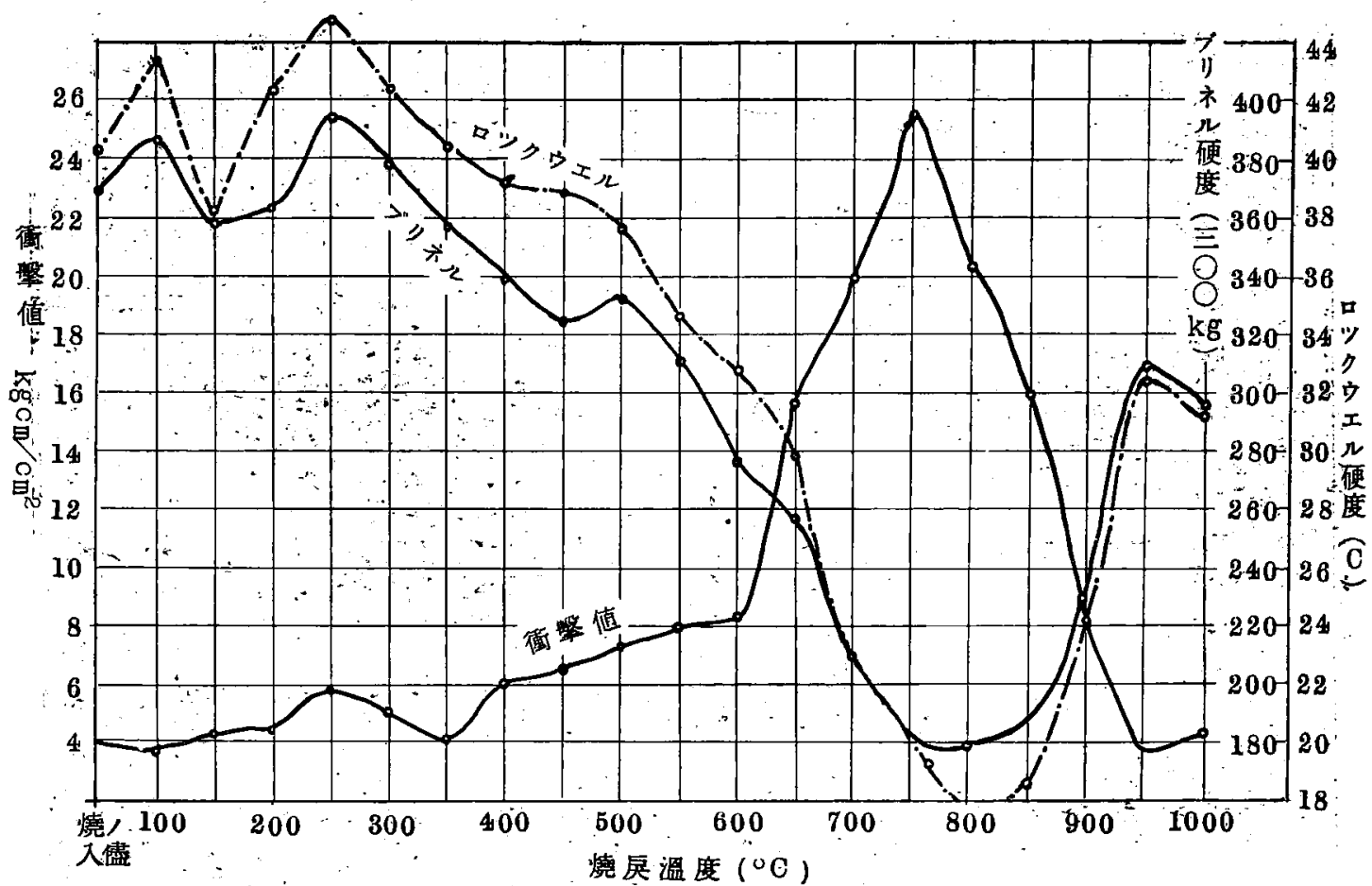

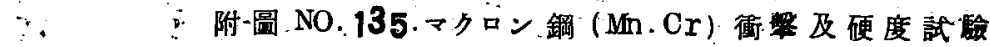

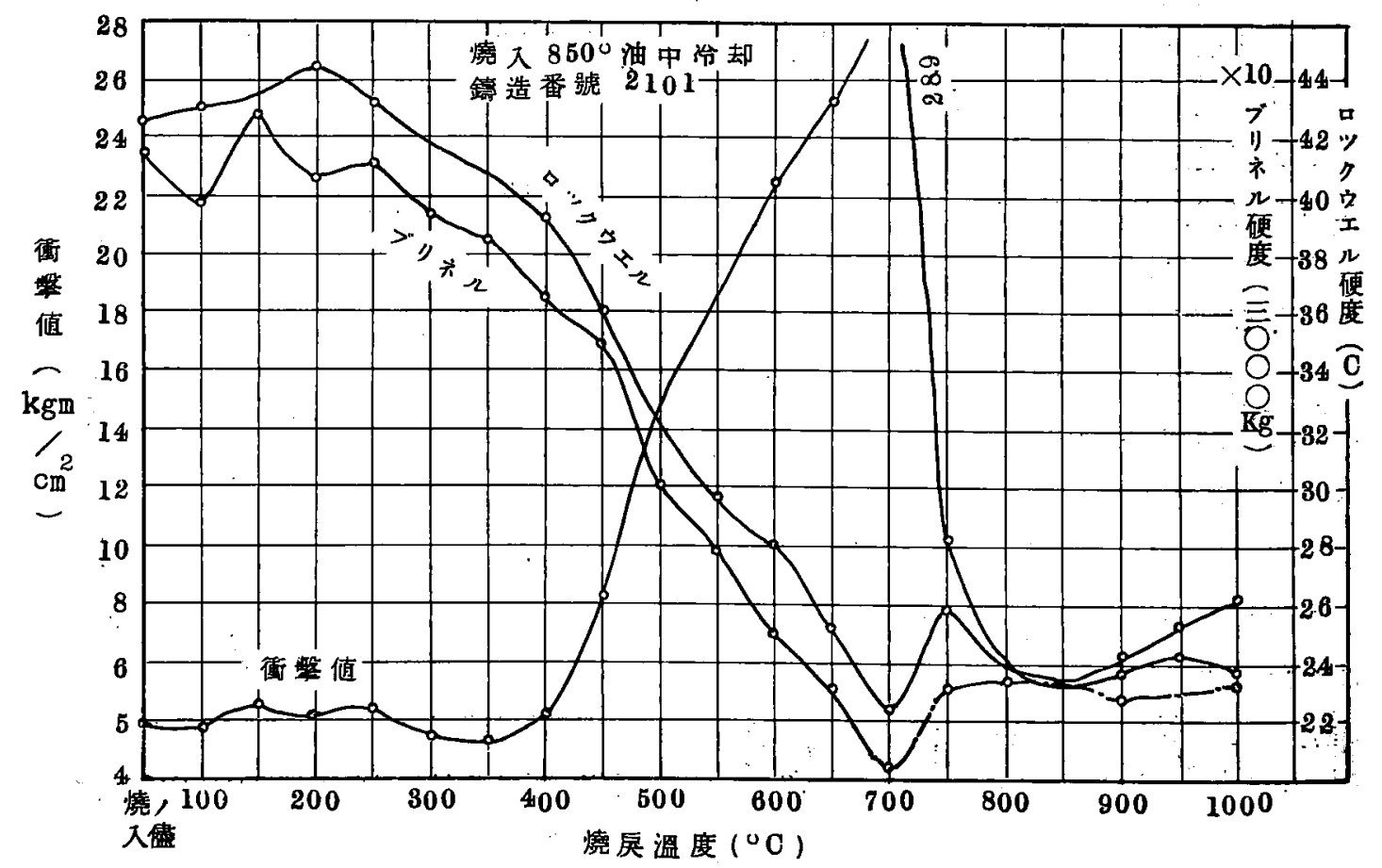




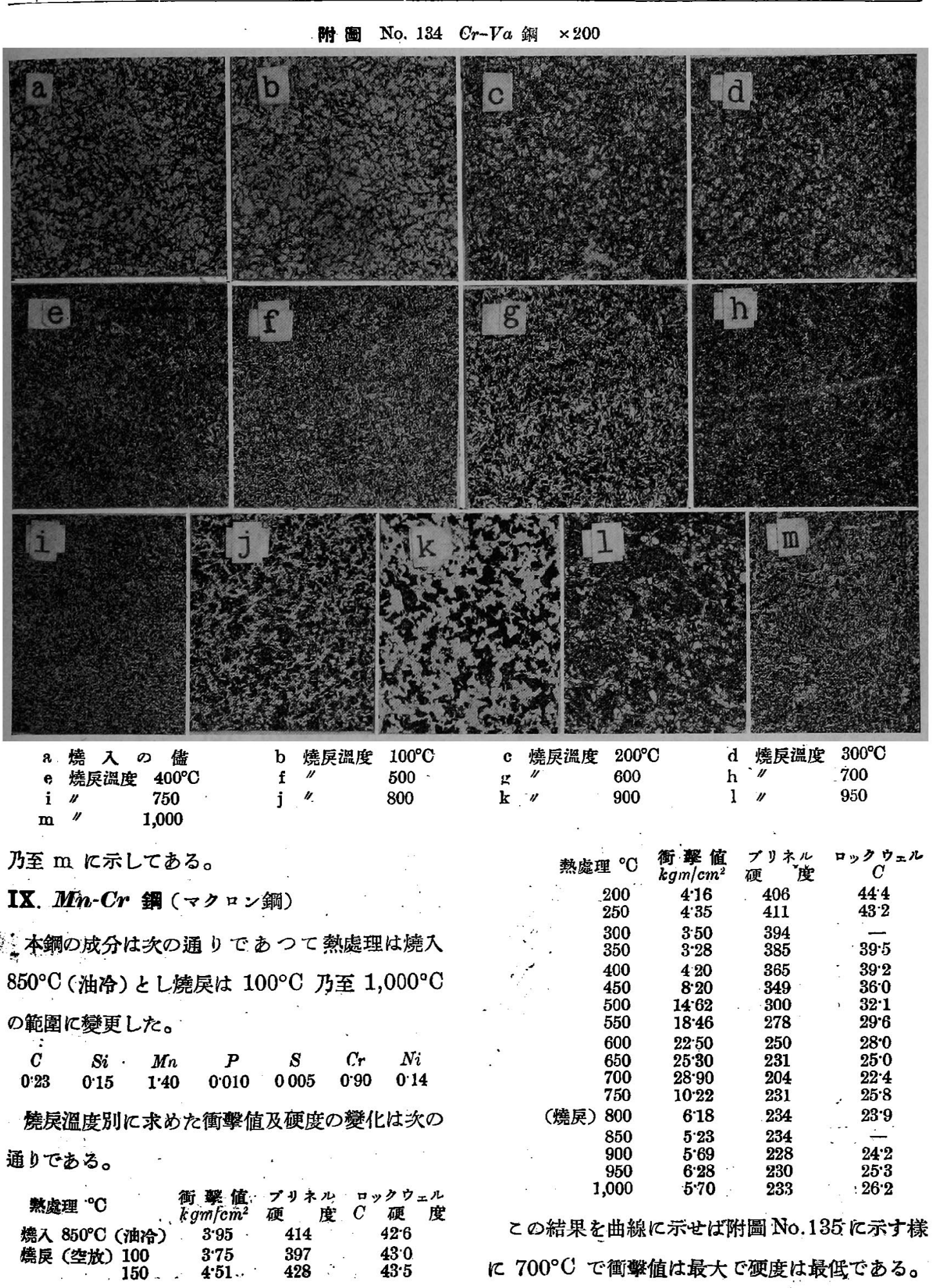




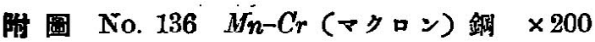

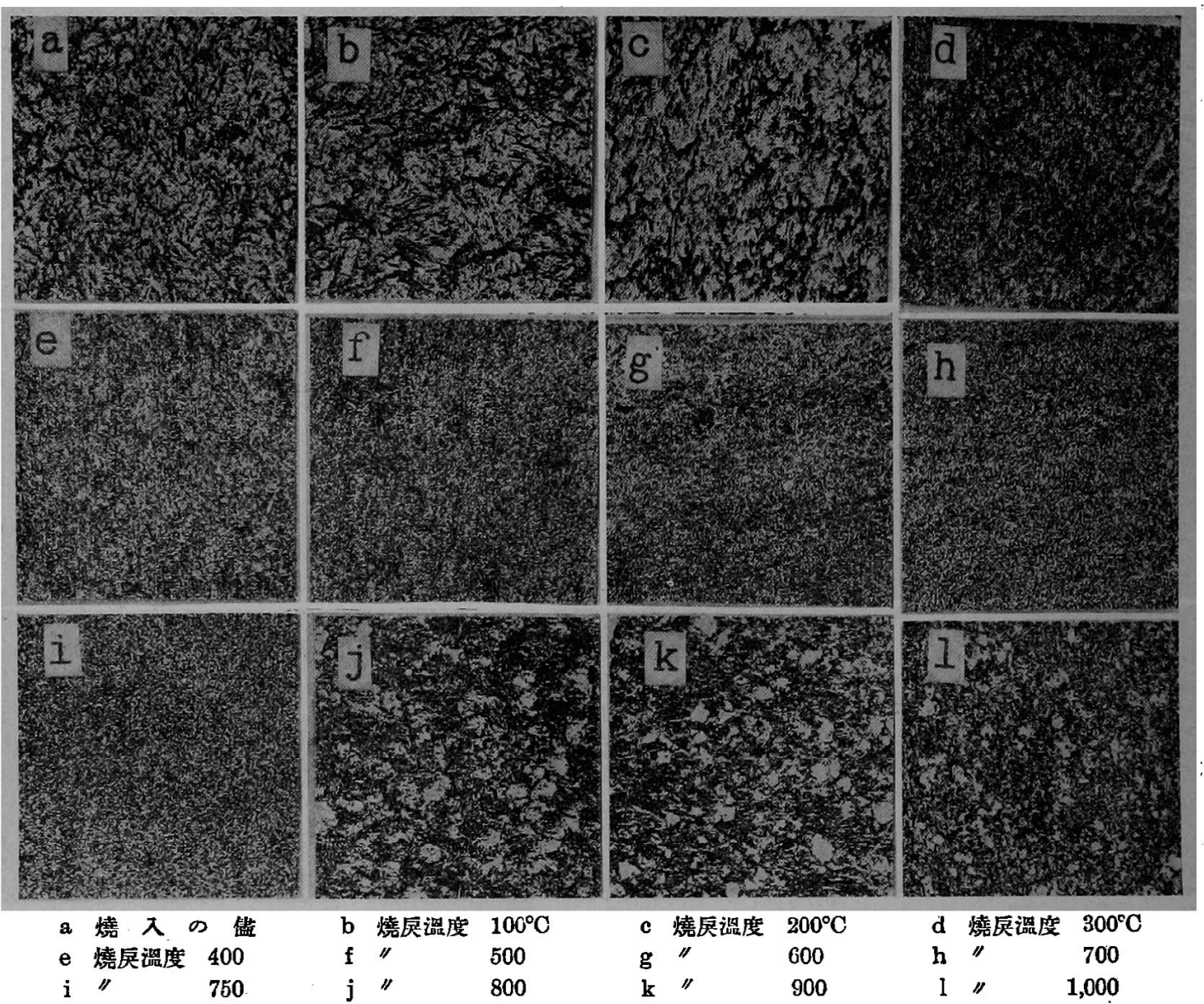

倘本鋼變態點以上で空中冷却の僖では燒入效果が 無い故に $750^{\circ} \mathrm{C}$ 以上では衝熬值当硬度も低い。 主要燒屈溫度に於ける組織は附圖 No.136a 乃至 lに示してある。

\section{X. $N i-C r-M o$ 鋼 (CN 12 鋼)}

本鋼の成分は次の通りであつて熱處理は燒入 $850^{\circ} \mathrm{C}$ (大氣中) とし燒㞔は $100^{\circ} \mathrm{C}$ 乃至 $1,000^{\circ} \mathrm{C}$ 範圍に變更した。

$\begin{array}{cccccccc}C & S i & M n & P & S & N i & C r & M o \\ 0 \cdot 24 & 0 \cdot 13 & 0 \cdot 39 & \text { tr. } & 0.006 & 2 \cdot 91: & 3 \cdot 00 & 0 \cdot 58\end{array}$

燒屎溫度别に求め‡衝整值及硬度の變化は次の 通りである。
熱處理 ${ }^{\circ} \mathrm{C}$

㷪入の锴 焼 居 100

" 200

1) 250

II $\mathbf{3 0 0}$

/ $\mathbf{3 5 0}$

/ 400

/ 450

" $\quad 500$

I 550

/ 600

/ 650

/I 700

, 750

II. 800

/ 850

II 900

/ 950

1,000

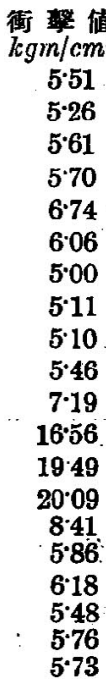

$>y * \pi$

ロックウェn ${ }_{449}$ 度 $\mathrm{C}$ 硬 $468 \quad 478$ $465 \quad 47 \cdot 4$ $469 \quad 47.0$ 458 . 46.8 $450 \quad 447$ $435 \quad 447$ $430 \quad 43.8$ 426 . 43.5 414 ! $\quad 426$ $405 \quad 40.9$ $325 \quad 323$ $300 \quad \mathbf{3 0} 3$ $280 \quad 267$ $359 \quad 36 \cdot 7$ $453 \quad 484$. $471 \quad 48.5$

$\begin{array}{ll}471 & 473\end{array}$

471 - 47.7 $468 \quad 487$ 
この結果を曲線に示せば附圖 No. 137 に示す 樣に $700^{\circ} \mathrm{C}$ では衝般值は最大で硬度は最低であ る。700 $\mathrm{C}$ 以上では宾中で燒入される雼に硬度は 高く衝擊値を低下する。倘主要燒㞔溫度に於ける
組織冲附圖 No. 139 a 乃至 k 亿示してある。

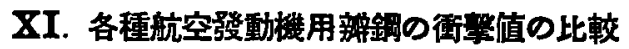

從來及現今使朋せられて居る主要な耐熱朋銅に 就き各種狀態の衝慗值を比较して見る。

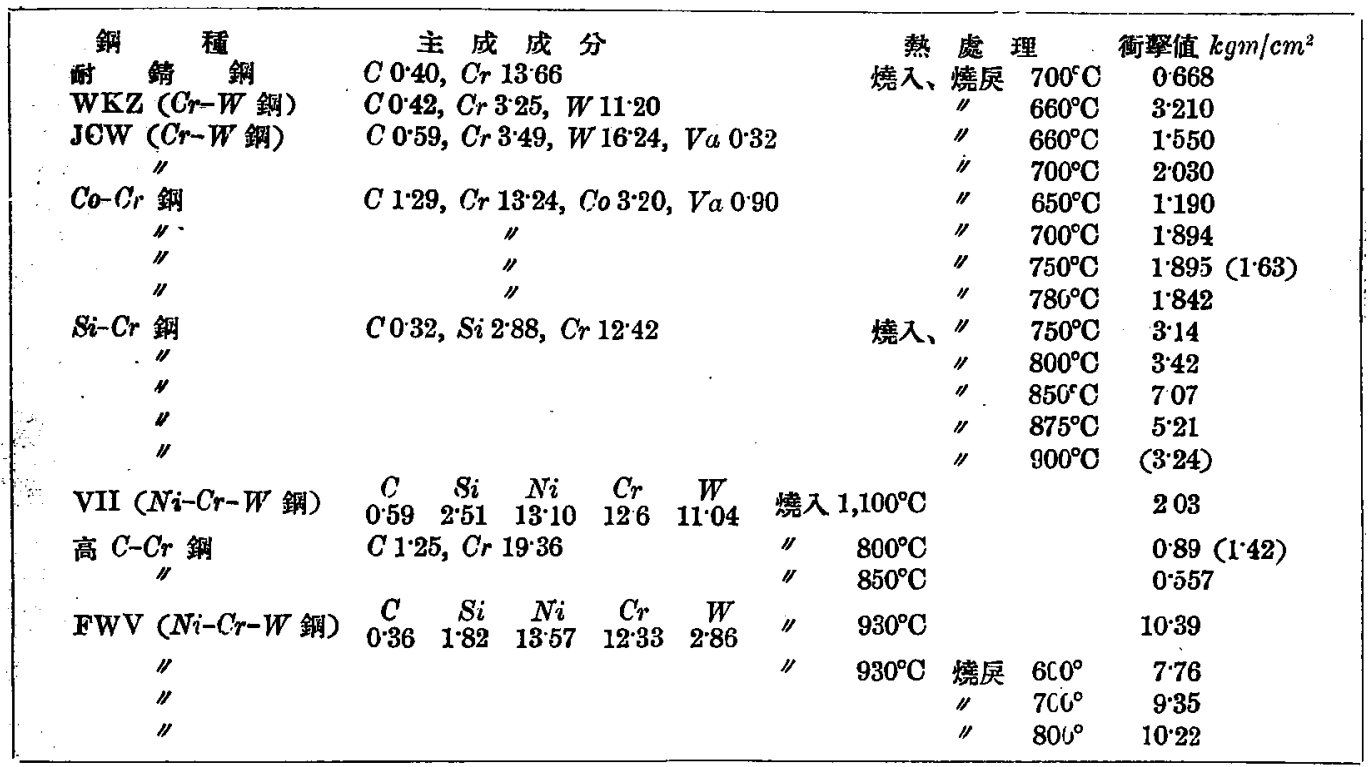

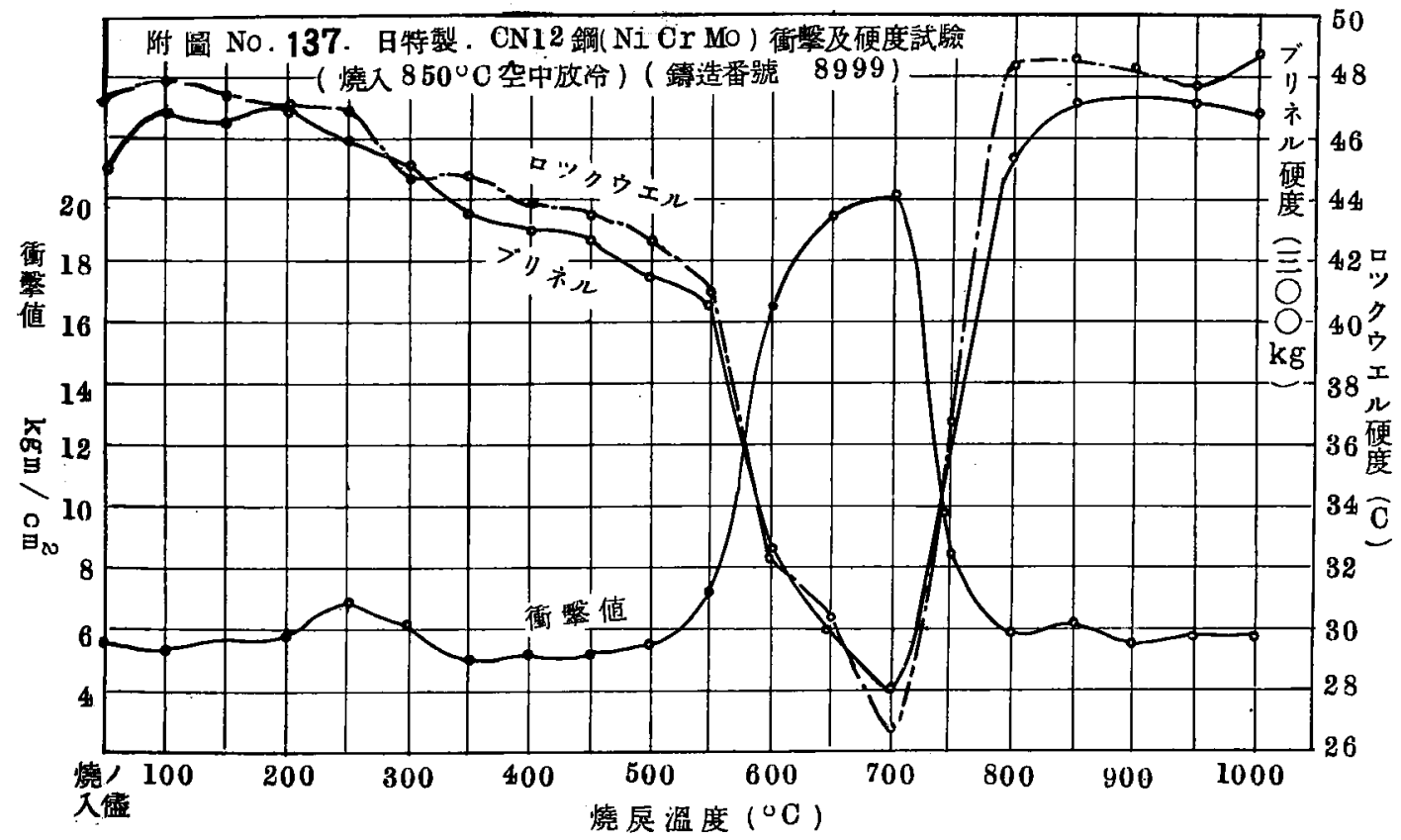


鐵と鋼 第十八年第十二號

坿圖 No. $138 N i-C r-M O$ 鋮 $\times 200^{-}$

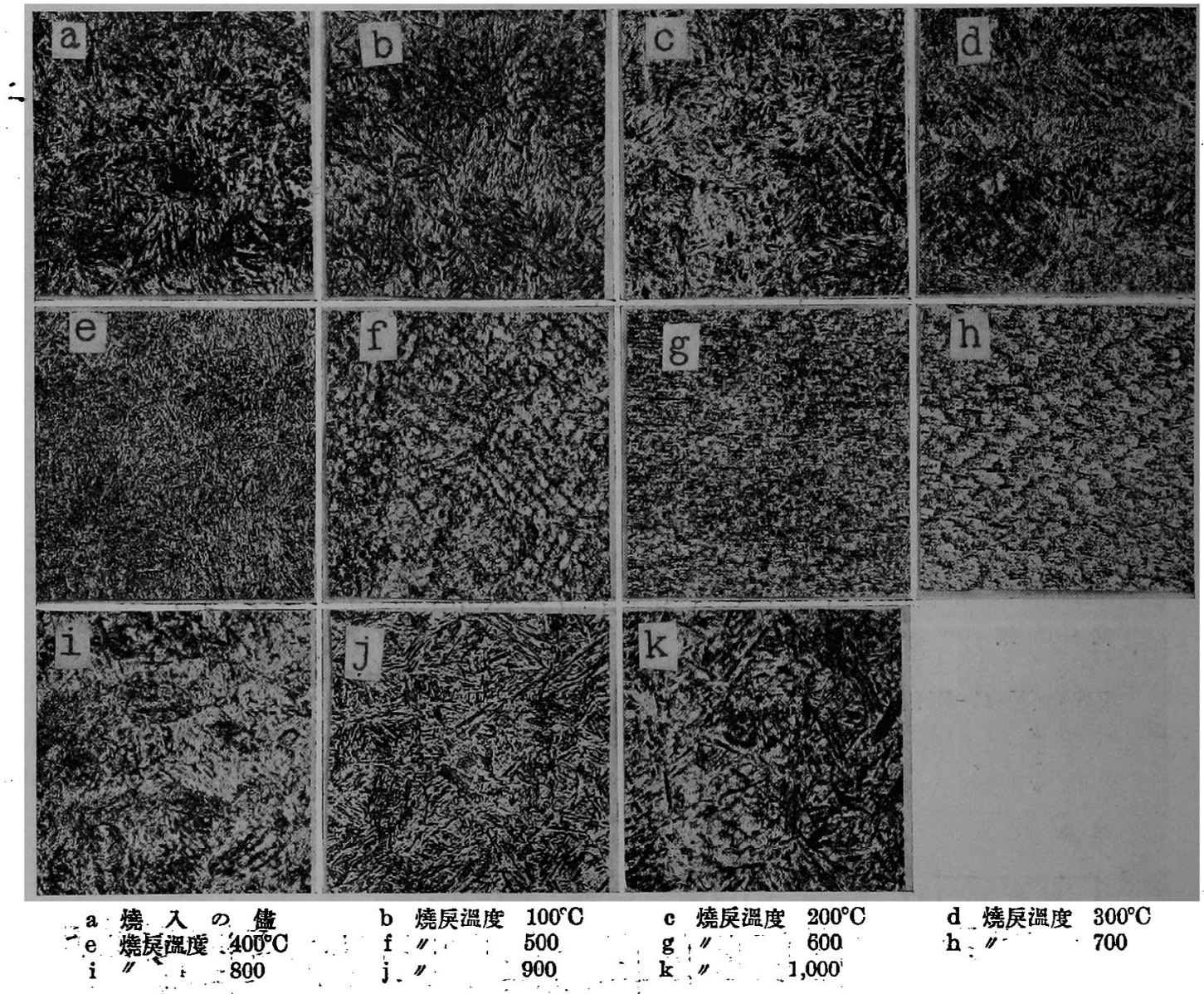

坿圖 No. 139 拿用銅街竳試驗

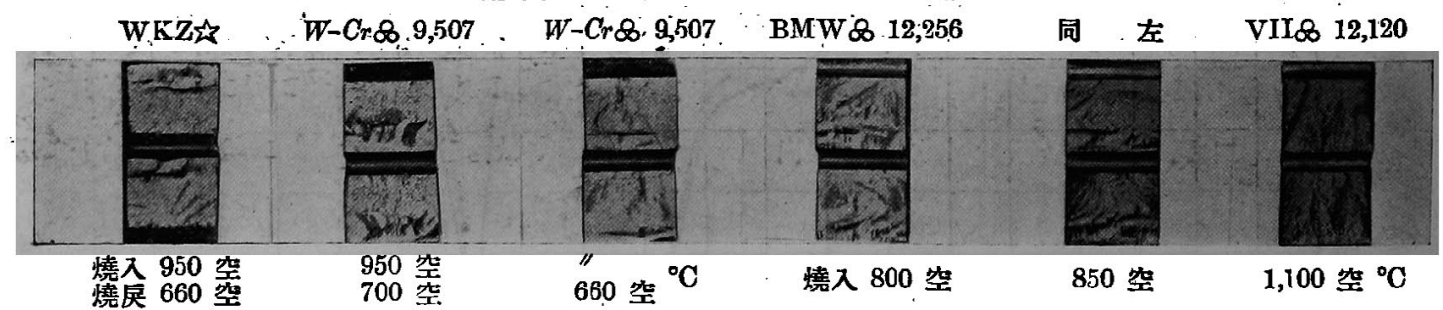

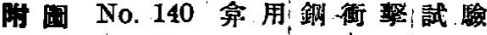

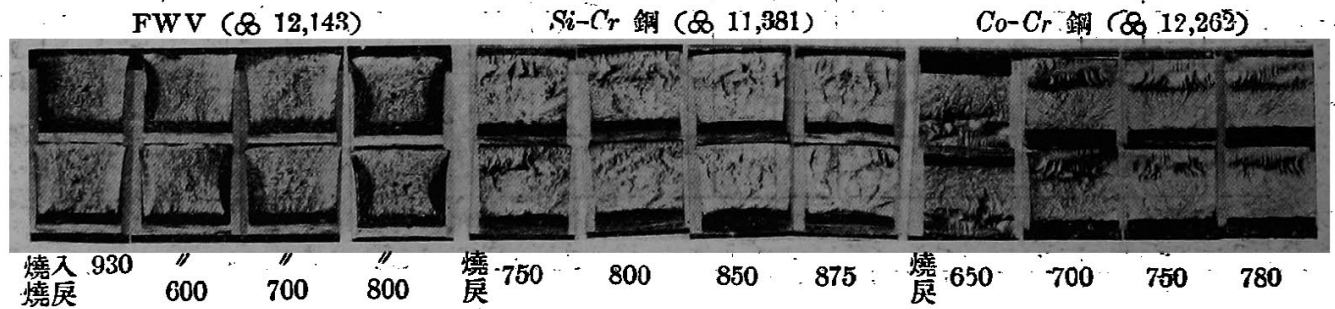


これ等試驗片の破面の景況は附圖 No. 139 及

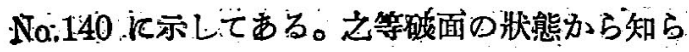

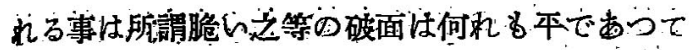

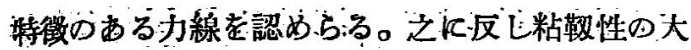

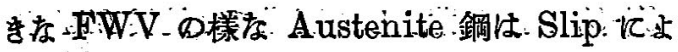
名變形が著し认゙。

\section{其 3; Gharpy 衝擊試驗片的破面江就て}

破斷面には細粒破面 (fine fracture) と粗粒破 面 (Coarce fracture) D外に二段刃は三段に異 字粒狀破面を得られる事もする。溝は Mesnager 型をして、その瑇の低部には所謂分離破断(Trennung）营起する。今最多く得られる破面を天 别する㭙は次の 4 種となる。

I，細粓脆性破面、燒入狀態不は著しく硬度の 高い合金鋼の破面に見られるるので附圖No. 141 及 No. 142 に示与樣に溝底中心基點 とし內部に放射狀に力線を認める場合、反對

腊圖 No. 141

高宸素クロム銅

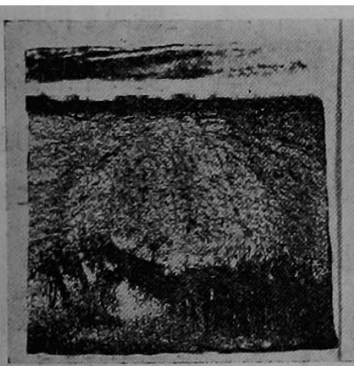

明 圆 Nó. 145 :

$0.45 \%$ 炭秦銅（脿鈍）
胕圆 No. 142

シベルト、クロム銅

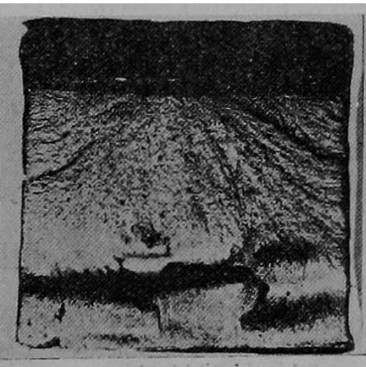

明圆 No. 146 $0.55 \%$ 宸素鈎 (燒針)
の側は壓力を受ける。

II. 細粒粘性破面， Sorbitê, Austenite

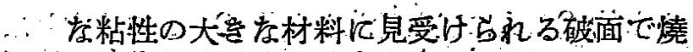

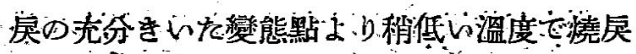

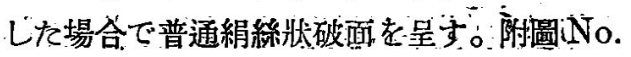
143 及 No. 144 参!

III. 組粒蹃性破面、Pearlite State 飞家岁麦素 鋼等つ破面であつて附圖:No.145 及 No.146 に示するす双は附圖 No. 147 它示す狀態は

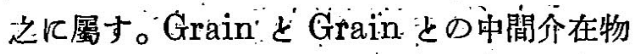

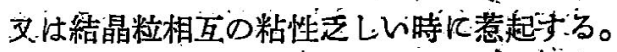

IV: 粗粒粘性破面、過熱さ视をFervite grain の場合に見受け方れる溙な破面で Grain

$\therefore$ Grạuth 等が原因で惹起する。.

今て等の破面の各種に就圆示士れば附圖 No. 148 の Fig. 1 乃至Fig. 4 となる。 Fig. 1

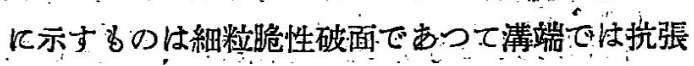

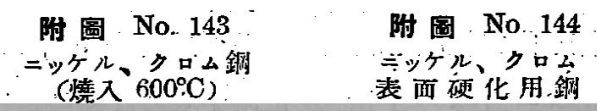

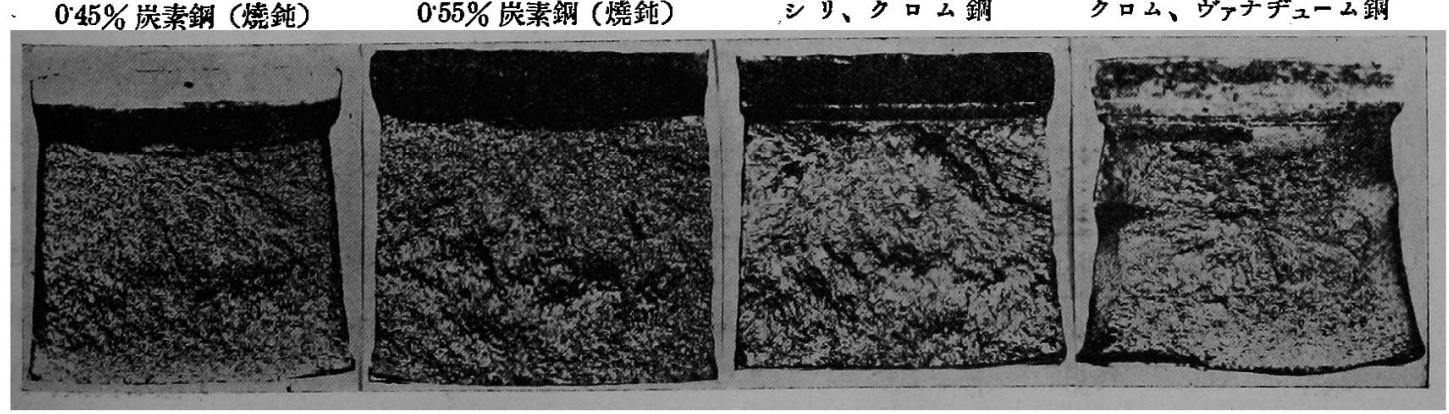


力を生じ打擊側では抗壓力を生じ、其中間に中立

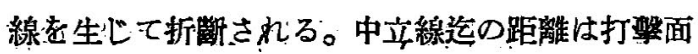
より約 $2 \mathrm{~mm}$ に亘りそれ占的 $2 \mathrm{~mm}$ に達すれば 抗張力が作用さ各事考推定される。而して溝底か

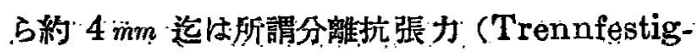
keit) と三元張力 (Triple Tension) とが作用 してみる事が想像せられる。，之等の關係を圖示す れば. Fig. 5 亿なる。圖中

$$
\begin{array}{ll}
\mathrm{Aa}, \mathrm{Bb}=\text { 分離抗張力 } & \mathrm{gk}, \mathrm{hl}=三 \text { 元張力 } \\
\mathrm{Dd} ; \mathrm{Ce}=\text { 抗帪力 } & \text { とする。 }
\end{array}
$$

之によれば ag，hb 曲線は一種の形状をなし gh が殆んどー直線である事は破面が同一である 事加ら推定される。又 Fig. 1 は fine fracture である故に aA 線の部迄等高で方てと( EF の中立線は $\mathrm{CD}$ 線よb約 $2 \mathrm{~mm}$ 亿在る事は 附圖 No.141でる明である結果から，大體 Fig. 5 の樣な內力線圆を想像さ水る(此場合 $\mathrm{ag}, \mathrm{hb}$ は殆んどー直線)、Fig. 2 亿示するのは細粒粘性 破面で附圖 No. 143 及 No. 144 はての代表的の るのでする。此場合の內力線圖は Fig. 5 亿示す るの殆んど同㮏で Aa は $\mathrm{kg}$ 上り滛に大である てと(破斷の時に於て)が想像される。從つて ag 間の內力傾斜の爲に Slip を生じ變形するもので ある。乙の場合の分離抗張力は $\mathrm{AD}, \mathrm{BC}$ の側闻
そ生ずるこさが分る。

Fig. 3 に示す娄のは特殊な場合で破面の中央 を境として溝の方向に粗粒: 他の方角に細粒を是 する場合が稀にる。本現象は Bohler CS 鋼 $\left(S i-C r\right.$ 銅) 飞惹起した現象で (燒戻 $650^{\circ} \mathrm{C}$ ) Charpy 試驗機の打擊の要領が何等かの異變によ り溝底部の張力を受ける際中立線を境として溝側 に三元張力が作用したるのと思はれる。刎論周圍 凡驻分離抗張力が作用し Slip を生じた事は剖に 同じ。Fig. 4 b特別の場合で偶然に $C r-V a$ 鋼

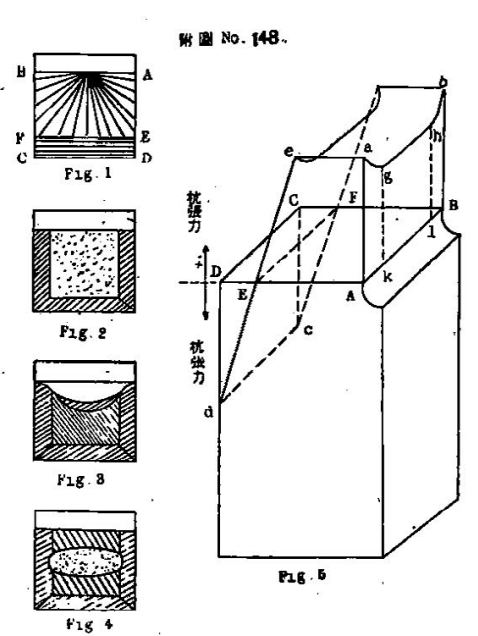

に之を發胃し だので恰す 涶を除いた斷 面の約 1/3の 中心に脆性破 面を生じ打籽 側には抗厴力 漂の側には抗 張力を同時に 受け中立區域 に三元張力を 受けたるのと考へられるが、之が顀際す機構に就 レては明ではない。附圆 No, 149 畲照。

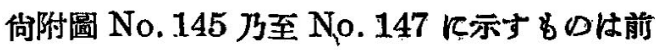
記粗粒脆性破面ですつて Pearlite 組織や $\mathrm{Si}-\mathrm{Cr}$
銅の樣な結晶の 發達した樣なる の江之れ反尿す るすのと思はれ る。乙の場合に 仗 Fig. 1 k示 す椿抗镸、抗 
㻺內力分布の形式にある事は想 像されると共に分離抗張力と三 元張力との荎の少い事る推定さ れる。

以上各種破面の景沉は前記各 程特殊鋼の燒杘溫度別に異つた 爿況にある事は附圖 No. 150 乃至 No. 158 に示してある。 之等を通覽する時は何れの場合 Kठ $A_{1}$ 變態點江近く鞁性最大 であつて衝擊值の最大の點があ る。普通使用狀態にはこの點上 り僅に低い狀態の處を撰んでる るが後述する樣に工作上の難易 を考へない時は衝擊値の最大の 狀態で性最耐久性がそしい事が 明であつて結局附圖 No. 143

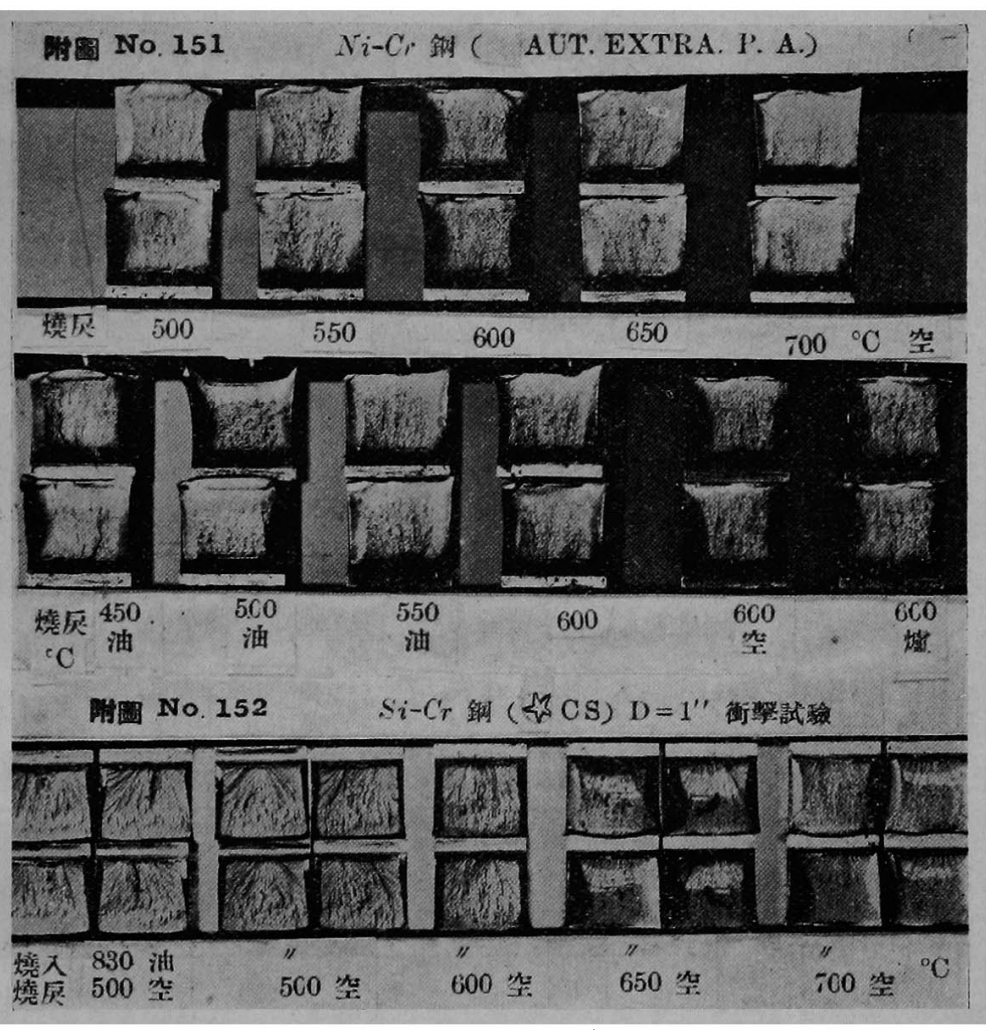

に示す樣な toughな狀態 比㝠用上は望 ましくないと 言はれる。

實際衝撃試 驗の棺で打つ 樣な大きな衝 整では確に靶 性の大きなる のが良いと稱 せられるが。 穿ろこの梯な 埸合は殆んぎ なくて僅かの

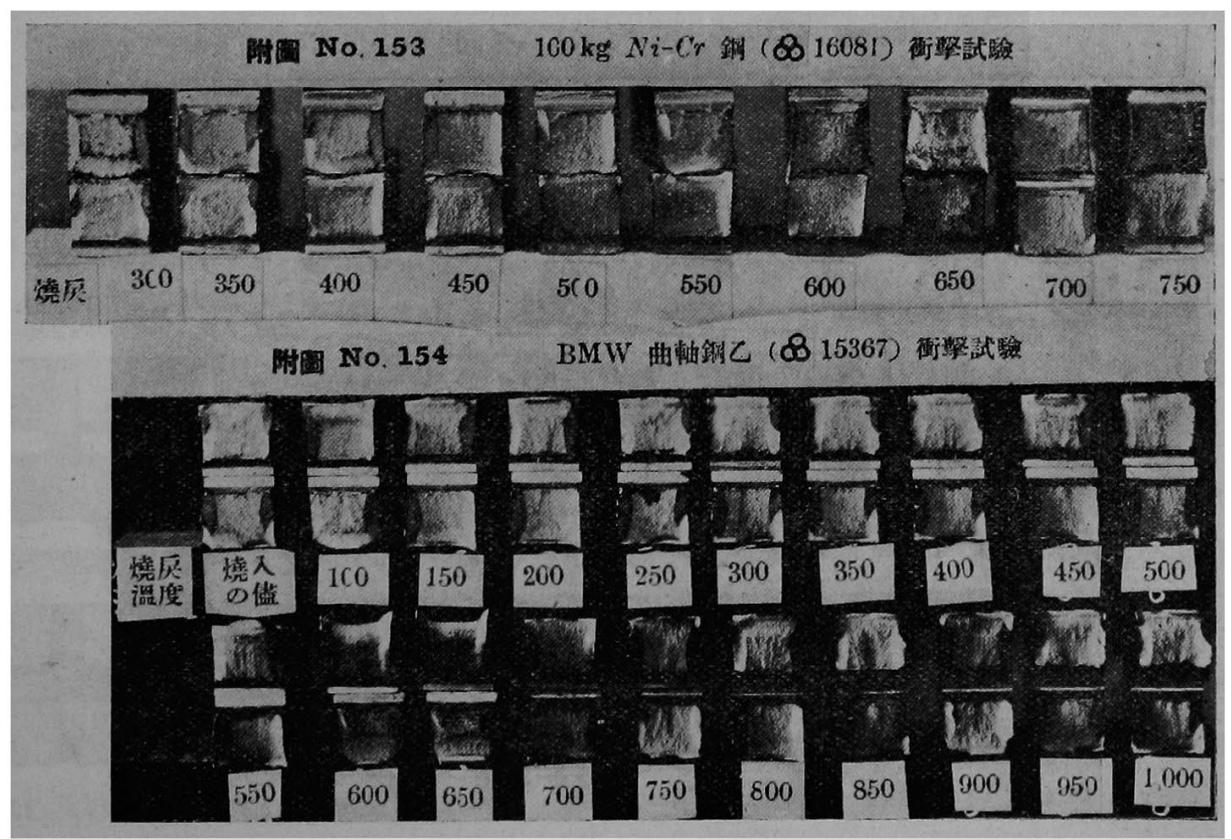



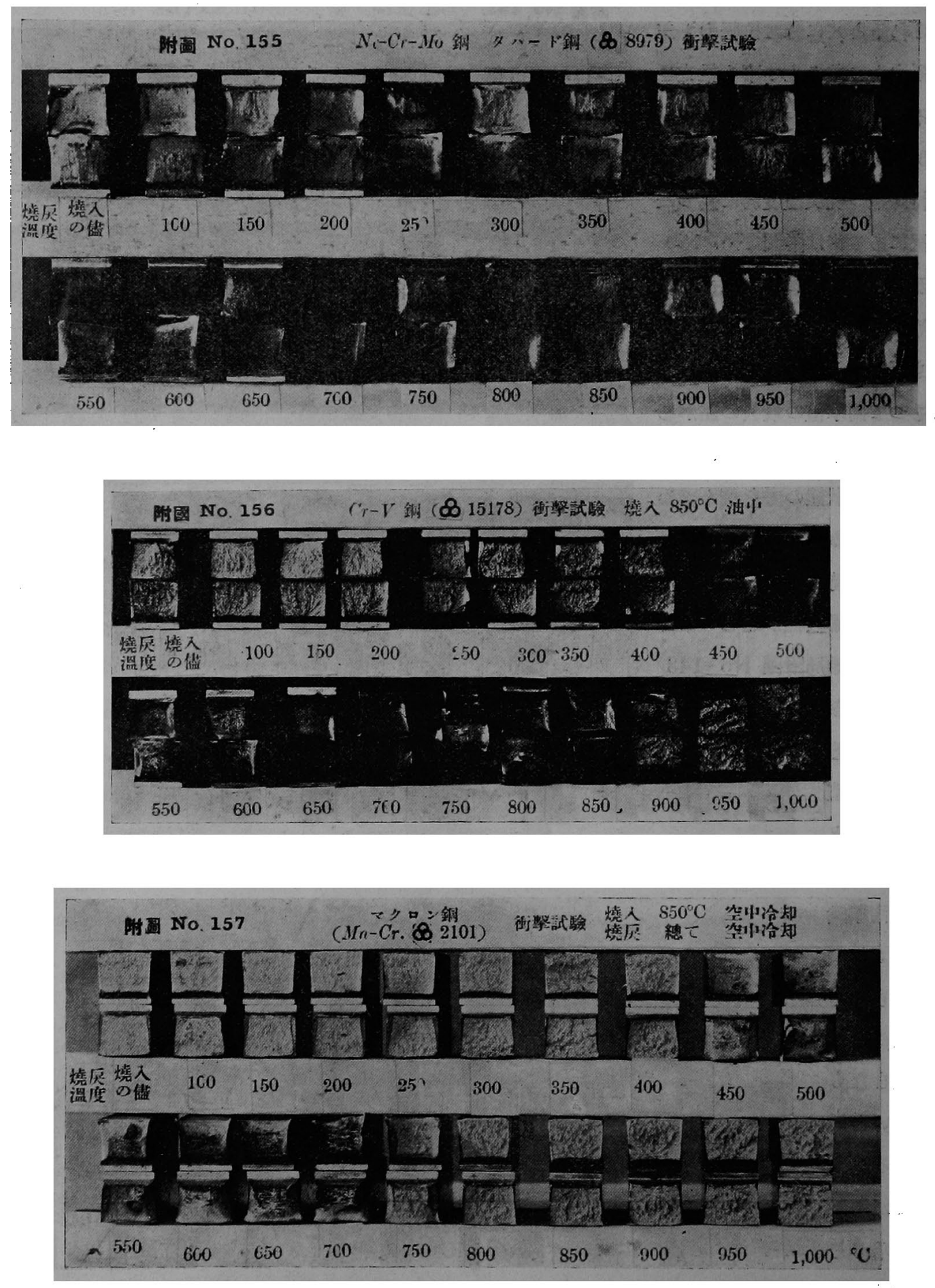


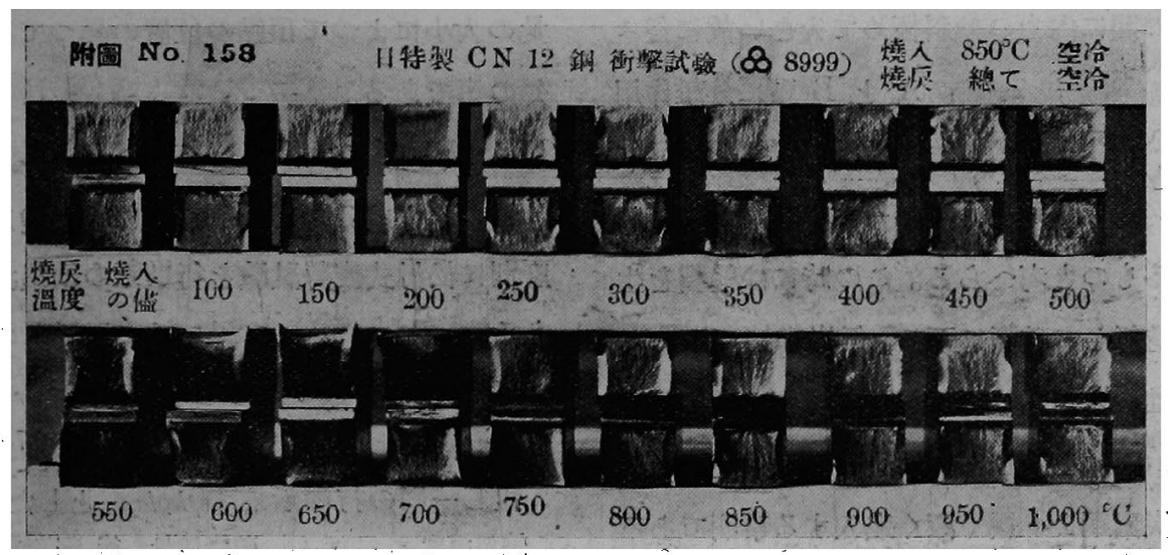

荷重の累耫による疲勞の場合に想到するならば衝 擊値は小であうてる前記細粒脆性破面を呈するす のは耐久力が大きい。但變態點を超えて粗粒脆性 を呈する樣な狀態では耐久性もこしい事が事實で

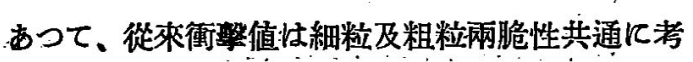
へて望ましくないと思つたすは安當では無い。耐 久性を重悓する航空機用材料では工作上差支人な ければ使用狀態としては細粒脆性は害なきのみな らす蜜ろ必要であるすのと思惟される。

\section{第3第 疲勞脆性}

粘鞀性の大きな鋼の疲勞に京る破断は殆んど脆 弱破面を呈する事は前述の通りである。今各種疲 勞試驗の中松村式疲勞試驗機及 Amsler Universal Hammer Machine による疲勞破斷に就き

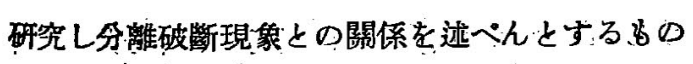
である、

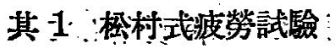

順序として先づ炭素鋼に就て述べ次に特種鋼の 各種熱處理狀態に於计る疲勞試驗結果を論し分離 破斷との關係を明にするととふす。

\section{I. 炭 素: 鋼}

C量を異にする次の 3 種鋼を撰び松村式繰返打 試驗機にて $30 \mathrm{~kg} / \mathrm{cm}$ の打繁活量による破斷回
數索試驗した。

熱處理は次の樣に燒鈍枋態としだ。

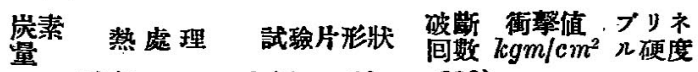

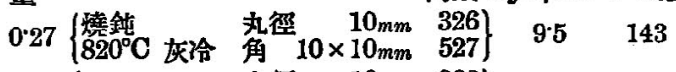

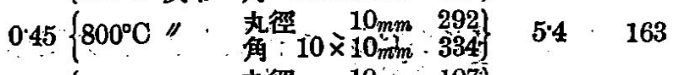

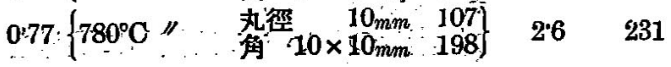
ての結果がら見れば炭素量の增如に從ひプリネ ル硬度は增し衝擊値は低下してみるが松村式の回 数注衙撃值に比例して其の他のるの反比例して

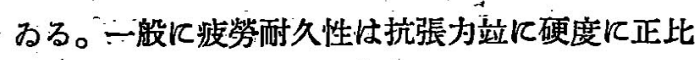
例するてとが多いで拘らずと反對である。ての 原因は打擊活量の大小と溝の影響によるものであ つて若し溝底部に生ずる表面內力が所謂分離抗張

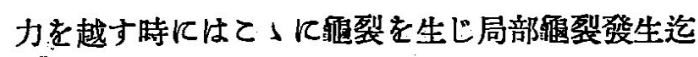
の旬數に大差ない時は破斷面@旬數戊硬脆なる材 料の方が少い事は推定に難くはない。

Pearlite 狀態沉在る炭素鋼では Ferrite と Pearlite $\left(F e_{3} C+F e\right)$ の境で打蒰力を受ける際 $\mathrm{A}$ 點の溝底部では著しく大きな分離抗張力を發生し 庈對側の溝底では抗壓力を生する。次に逆に打誓 を受ける時は全々之に反對の力を受け從つて A $\mathrm{B} の$ 兩局部では大きな分離抗張力を繰返し受ける 時は加工されるととななつて而も A B 點から僅 
に內部との間に內力の傾科極めて大きい故に益に

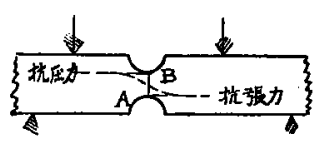

$\mathrm{A}$ \& $\mathrm{B}$ 點几分離作用

を進捗し變質して最後

の一蒰で分攡する樣な

狀態となるるのと考へらる。この時には䒴裂を生 じ我裂が進行して破斷に至る。低炭素銅ではFerriteゆ粘性大きい第めに變形を生じつ」遂に表面 のTrennung を生じて後は㸠裂の進入速度は比

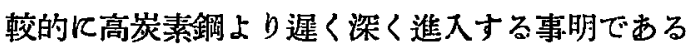
第めに全䜺の破断回數は低炭素鋼の力多いるのと 考へられる。絹䋃狀破面を生するのはTrennung

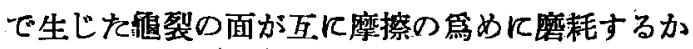
らである。

若し打擊倚重が小であつて高紫素鋼で而行久限界 以下の場合でも炭素量の爪んひのは僅が限界を 超過するてとがあつて、この場合は逆に高炭素鋼 の方は耐久性大である譯である。附圖 No. 159 參照。

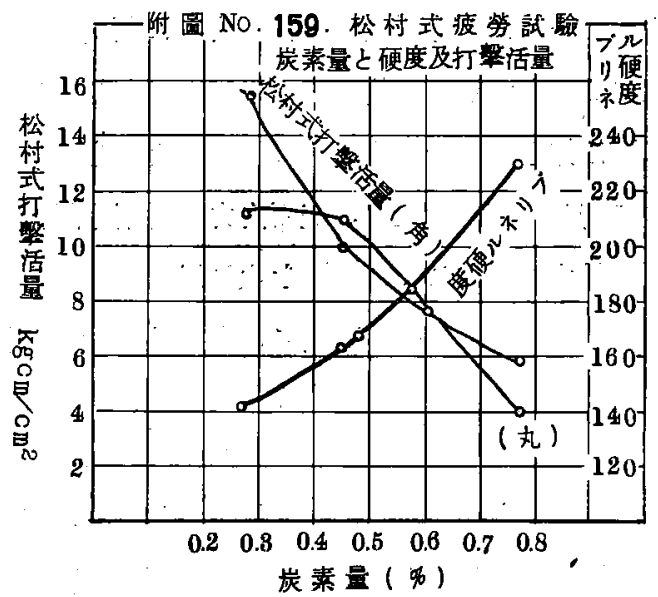

各種炭素鎡の燒入後低溫燒戻を行つて烃忖式打 撃回数の變化を試驗した結果は松下德次郎氏が發 表されて $C=0.45 \%$ 附近のものが約 $400^{\circ} \mathrm{C}$ で最 大间數を得られる賽驗は周知の事實であつて炭素
量の大小によつて頂點の位置の異つてるる事も周 知の事である。

II. $\mathrm{Ni}-\mathrm{Cr}$ 鎆 $\left(\mathrm{Ne}_{3}\right)$

次に示す成分の $\mathrm{Ni}-\mathrm{Cr}$ 鋼に就き燒入後燒戻溫 度別に松村式疲勞試驗を行いその結果次の通りで ある。

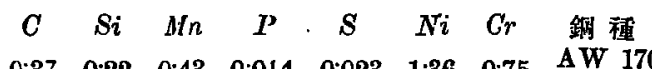
$\begin{array}{lllllllll}0.37 & 0.22 & 0.43 & 0.014 & 0.023 & 1.36 & 0.75 & \Delta W_{8970} & 170\end{array}$

但し一包の打繁活量 $30 \mathrm{~kg} / \mathrm{cm}$ とした。

\begin{tabular}{|c|c|c|c|c|}
\hline 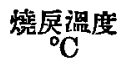 & 破断包數 & $\begin{array}{l}\text { 破菥活量 } \\
\mathrm{kgm} / \mathrm{cm}^{2}\end{array}$ & 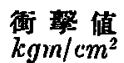 & 硬 度 \\
\hline 300 & $1518 \cdot 7$ & 45,650 & $3 \cdot 25$ & 401 \\
\hline 400 & 29730 & 89,800 & $4 \cdot 15$ & 377 \\
\hline 500 & 18630 & 56,150 & $8 \cdot 51$ & 285 \\
\hline 550 & 1807.5 & 54,850 & 1377 & 254 \\
\hline 603 & 1354.5 & 40,800 & $18 \cdot 4$ & 224 \\
\hline 650 & $1175 \cdot 5$ & 35,080 & $21 \cdot 6$ & 201 \\
\hline 700 & $1119 \cdot 5$ & 32,720 & 148 & 184 \\
\hline
\end{tabular}

この結果柱附圖 No. 160 と示してある通り燒 戻 $400^{\circ} \mathrm{C}$ の場合には $300^{\circ} \mathrm{C}$ の場合上り遙に耐 久力大であつて之 $400^{\circ} \mathrm{C}$ 以上では急に低下する。 500 550 $\mathrm{C}$ 附近で停止點のある事す特幑であ る。 $400^{\circ} \mathrm{C}$ 附近は所謂 Blueing Temperature であつてての種衝擊力による耐久性では最强いて とが知られる。之に煋し Charpy 式衝撃試驗の 樣を唯二回の打慗に上る場合とは反對の現象を示 してるる。即ち燒戻溫度が $600,650,700^{\circ} \mathrm{C}$ と

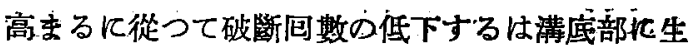
和る Trennfestigkeit は溫度の上星と共に低く なる霨めで殊に $650^{\circ} \mathrm{C}$ を過ぐる時は Sorbite が $F e_{3} C+F e$ の所謂 Pearlite 分解して grain boundary $儿$ 出來る䉆め前粗粒脆性を呈する䉆 めに速に震動的打等荷重に上つて疲勞し分離破断 を促進するのである。

破斷面を精細に觀察するに中央部に脆弱帶部の 出来る事は附圆 No.161 亿示す通りであつて其 の幅は燒戻溫度と共に變化してわる。而して 550 

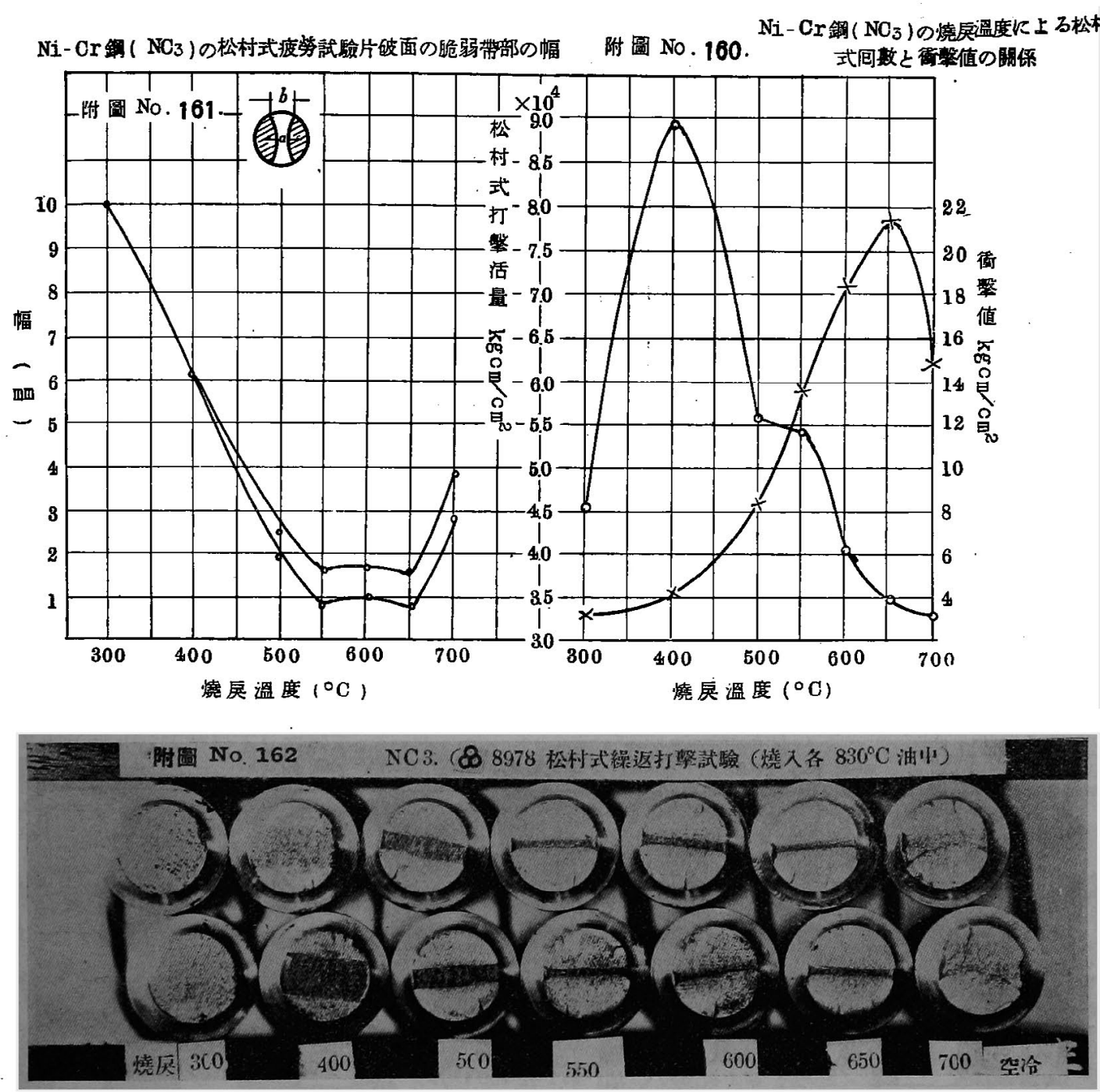

${ }^{\circ} \mathrm{C}$ 迄は其の幅が㴬次に小となり $550^{\circ}$ 乃至 650 ${ }^{\circ} \mathrm{C}$ 迄では殆んど一定する爿沇は附圖 No. 162 凡 示す通りである。700 ${ }^{\circ} \mathrm{C}$ に於ては急に幅を製大す る。ての幅の大なることは脆性の大なる事を示す るので $300^{\circ} \mathrm{C}$ 燒戻の場合には帶部が焦い。即ち 外面に起る分離抗張力以上の荷重がかっるときに

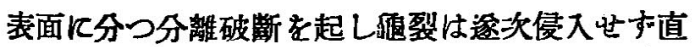
ちに破斷に至るととを示してるる。からる細粒脆 性の場合には繰返荷重による變質(加工の爲め)し

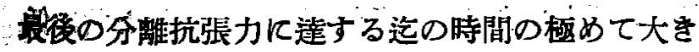

レか一度艇裂が出桃た後は內部迄力の傳播する事 速で直ちに破斷する。打整荷重の最極端に大きい 衝撃試驗では粗粒と細粒とを問はす硬度の大な るものは衝盤値小となるに反し松村式疲膋の場 合には細粒脆性の燒戻 $400^{\circ} \mathrm{C}$ の場合上粗粒脆 性の燒戻 $700^{\circ} \mathrm{C}$ の場合とは全々趣を哄にし て後者の場合は $F e_{3} C+F e$ なる介在物が出柬る 鳻めに震動的疲勞には著しく弱い事を知るのであ る。破面の景況は附圖 No. 162 に示す通りであ る。 

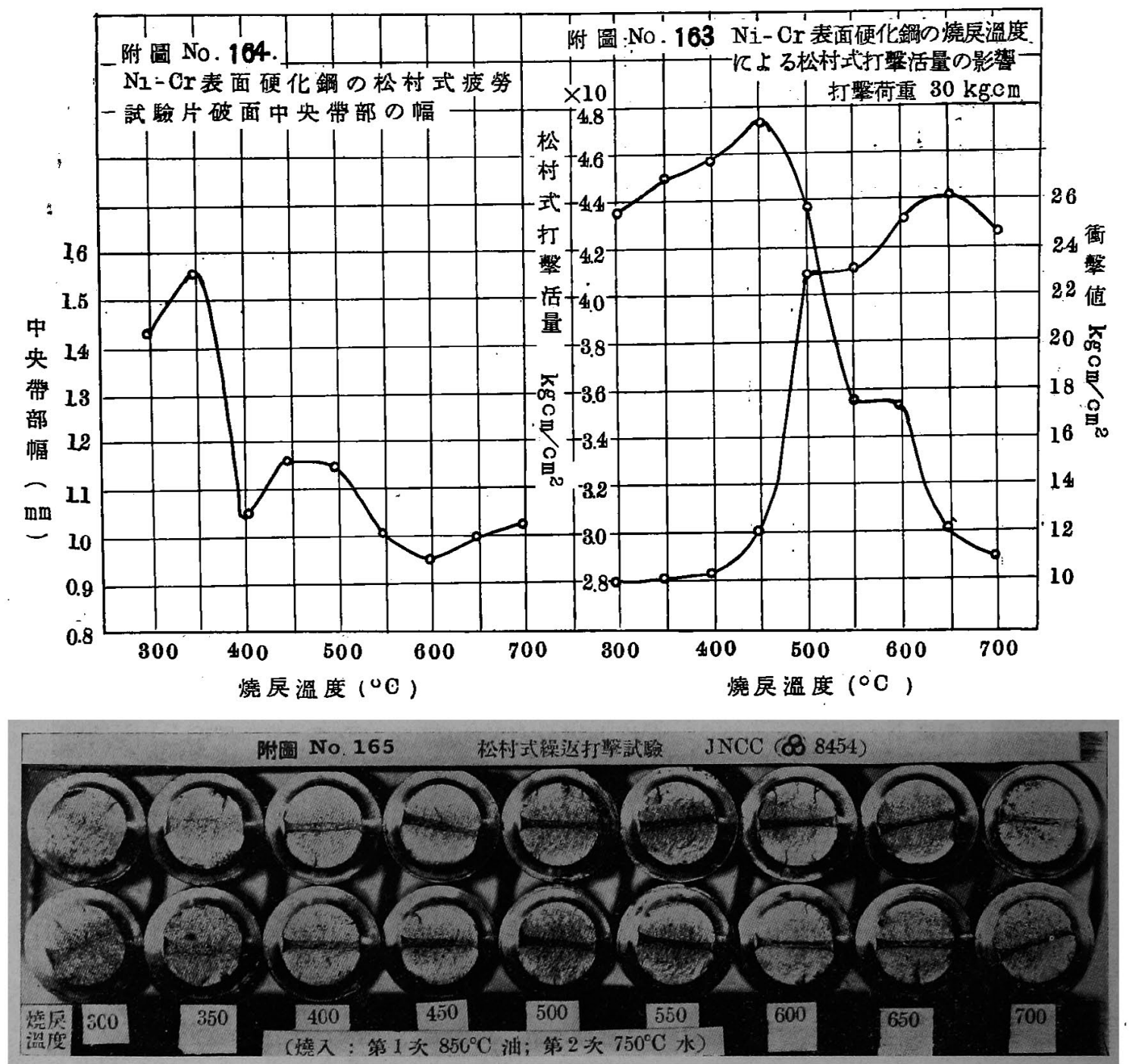

III: $N i-C r$ 表面硬化鋼 (JNCC)

本銅は Case hordening 佣銓である故に二。重 燒入して使用するが特に燒入後燒戾溫度を變化し て松村式疲勞試驗を行つて衝媻值や硬度との關係 を試驗した。この結果は附圖 No. 163 亿示して ある。乙の結果から見れば $300 \mathrm{C}$ から $450^{\circ} \mathrm{C}$ 迄

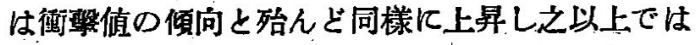
全々反對の傾向をとり $500^{\circ} \mathrm{C}$ 儿達すれば之以上

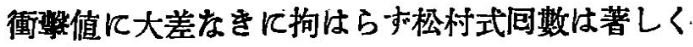

低下してるる。尚 $550 \sim 600^{\circ} \mathrm{C}$ 亿於て松村式句數 の停止點のある事は前に同じ。佾破斷面の脆性帶 部の景沙は附圆 No: 164 亿示寸破面の景況は附 圖 No. 165 に示す通りである。，

IV. $N i-C r$ 牛硬鋼 ( $86 \mathrm{~kg} N \cdot i-C r$ 鋼)

本試驗では特に九型及角型の雨試驗片の斷面輤 を各 $1 \mathrm{~cm}^{2}$ とし各種燒杘溫度を變化する事による， 松村式破斷回数影響を見を、その結果は附圖 No. 166 に示してある。大鹃燒㞍溫度の上昇と共に低 


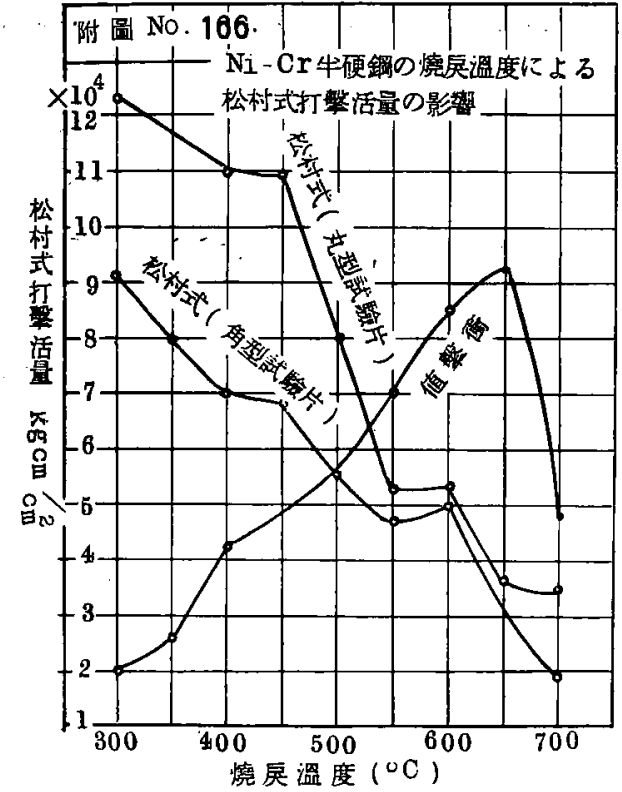

下する事及 $550^{\circ} \mathrm{C} \sim 600^{\circ} \mathrm{C}$ の點で停止點の存在 する事む同前である。衝繋值は $650^{\circ} \mathrm{C}$ で最大で あるが松村式は連續低下して居る。

尚丸型は角型に比し松村式回數の大なる理由は

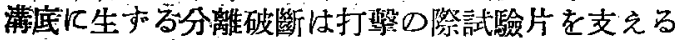
兩支點を安定狀態に置く篇めにその效果は㑲型の 大なるものと考心られ特に細粒脆性狀態にて差は 大糔几 ( $450^{\circ} \mathrm{C}$ 燒戾の時最大) 而して $550^{\circ} \mathrm{C}$ 、 $600^{\circ} \mathrm{C}$ Ф場合では差が極めて小となる。700 $\mathrm{C}$
で再び其の差大となつたのは粗粒で脆性となつた てとを知る。破斷面の景況は前と同梯に $300^{\circ} \mathrm{C}$ の場合に中央帶部の幅最大で盜度上昇と共に㷋く なる。 $700^{\circ} \mathrm{C}$ で再び大となり而も破斷回數る低 下してるる。

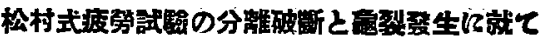

松村式疲勞試驗は打般によつて生起する內力が 試驗片の满底で繰返し作用し試驗片が反轉する事 により抗張抗暨力が交互に起り從つて該部が加工 される事となり桷次に分離破断力の變化を來し逐 に最後の一打盤によつて局部に分離現象を起す。 ての結果挋裂となり逐に䞟裂が深く侵入する事に より破断に到達す。今甸裂墢生の回數と破斷回數 との間に何等かの留係あるやを試驗する篇めに各 程特殊銅の蓺處理別に於ける将態を研究するとと \した。試驗片寸法は次の 2 種とした。

角形試驗片 $15 \times 10 \mathrm{~mm}$ 瀿断面 $10 \times 10 \mathrm{~mm}$

沈形試驗片，徑 $15 \mathrm{~mm}$ 溝 徑 $11.29 \mathrm{~mm}$ 溝方断面皘は何礼子 $100 \mathrm{~mm}$ である。供試特殊 鋼の成分及之等銅の熱處理要领は次表め通りと ఫ。

\begin{tabular}{|c|c|c|c|c|c|c|c|c|c|}
\hline 牧: “路 & 1 铜 & . & . & & 分. 析 & 战一分 & & & \\
\hline NS & T理 & $\bar{C}$ & $\mathrm{Si}$ & $M n$ & $N_{i}$ & $\mathrm{Cr}$ & $W^{-}$ & 其 & 他 \\
\hline $\begin{array}{l}\text { Bohler Anto } \\
\text { Exlra PA }\end{array}$ & $\mathrm{Ni}-\mathrm{Cr}$ 銅 & 015 & 0.32 & 0.45 & $2 \cdot 49$ & 0.68 & & & \\
\hline $\begin{array}{l}\text { AW20( } \times 527) \\
\text { Bohler CS }\end{array}$ & $\begin{array}{l}N i-C_{r}-M o \text { 銅 } \\
\text { Si-Cr 銅 }\end{array}$ & $\begin{array}{l}0.36 \\
0.52\end{array}$ & $\begin{array}{l}0.27 \\
0.90\end{array}$ & $\begin{array}{l}0.33 \\
0.35\end{array}$ & 281 & $\begin{array}{l}0.66 \\
1 \cdot 24\end{array}$ & & $\begin{array}{l}\text { Mo } \\
M o\end{array}$ & $\begin{array}{r}074 \\
0.35\end{array}$ \\
\hline $\begin{array}{l}\text { H-Cr (9108) } \\
\text { FWV } \\
\text { VII (12120) }\end{array}$ & $\begin{array}{l}\text { 亳 }-C r \text { 銅 } \\
N i-C r-W \text { 銅 } \\
N i-C r-W \text { 鈎 }\end{array}$ & $\begin{array}{l}0.40 \\
0.36 \\
0.59\end{array}$ & $\begin{array}{l}0 \cdot 36 \\
1.82 \\
2 \cdot 51\end{array}$ & $\begin{array}{l}0.32 \\
0.34 \\
0.39\end{array}$ & $\begin{array}{l}13: 57 \\
13: 10\end{array}$ & $\begin{array}{l}13 \cdot 66 \\
12 \cdot 33 \\
12 \cdot 60\end{array}$ & $\begin{array}{r}286 \\
11 \cdot 04\end{array}$ & $V a$ & $0 \cdot 2$ \\
\hline $\begin{array}{l}W-C r(9507) \\
\text { BMW }(12256) \\
\text { CN } 12\end{array}$ & $\begin{array}{l}W-C r \text { 銓 } \\
\text { 高 } C-C r \text { 鐝 } \\
N i-C r-M u\end{array}$ & $\begin{array}{l}0.57 \\
1.25 \\
0.24\end{array}$ & $\begin{array}{l}0 \cdot 10 \\
0 \cdot 60 \\
0 \cdot 13\end{array}$ & $\begin{array}{l}0.09 \\
0.41 \\
0.39\end{array}$ & $2 \cdot 91$ & $\begin{array}{r}3 \cdot 13 \\
19 \cdot 86 \\
3 \cdot 00\end{array}$ & $15 \cdot 89$ & $\begin{array}{l}\text { Ya } \\
M o\end{array}$ & $\begin{array}{l}0.5 \\
0.58\end{array}$ \\
\hline
\end{tabular}

\begin{tabular}{|c|c|c|c|c|c|c|c|c|c|}
\hline 据 & 分 & $\begin{array}{l}\text { Bohler Anto } \\
\text { Exrap A }\end{array}$ & AW 20 & $\begin{array}{c}\text { Bohler } \\
\text { CS }\end{array}$ & $\dot{\mathrm{H}}-\mathrm{Cr}$ & FWV & VII & $W-C r$ & BMW \\
\hline $\begin{array}{l}\text { 燒 } \\
\text { 焅 }\end{array}$ & $\begin{array}{l}\text { 釛 } \\
\text { 入. }\end{array}$ & $\begin{array}{l}820^{\circ} \mathrm{C} \\
850^{\circ} \mathrm{C} \text { (油) }\end{array}$ & $\begin{array}{l}830^{\circ} \mathrm{C} \\
850^{\circ} \mathrm{C} \text { (油) }\end{array}$ & $\begin{array}{l}800^{\circ} \mathrm{C} \\
830^{\circ} \mathrm{C} \text { (油) }\end{array}$ & $\begin{array}{l}900^{\circ} \mathrm{C} \\
930^{\circ} \mathrm{C} \text { (油) }\end{array}$ & $930^{\circ} \mathrm{C}$ (空) & $1,100^{\circ} \mathrm{C}$ (空) & $\begin{array}{l}900^{\circ} \mathrm{C} \\
950^{\circ} \mathrm{C} \text { (空) }\end{array}$ & $800^{\circ} \mathrm{C}$ (烓) \\
\hline 煏 & 戻 & . & $\begin{array}{r}500^{\circ} \mathrm{C} \sim \\
.700^{\circ} \mathrm{C}\end{array}$ & $\begin{array}{r}500^{\circ} \mathrm{C} \sim \\
700^{\circ} \mathrm{C}\end{array}$ & $700^{\circ} \mathrm{C}$ & & & $600^{\circ} \mathrm{C}$ & \\
\hline
\end{tabular}


打擎荷重は FWV 及高 $C r$ 鋼(9108)のみは

る。之等の關係は附圖 No.167 及び No.168 に 10. 20：30; 40.:50kgcm : ट し其他 は何れ $30 \mathrm{kgcm}$ 泣定した。

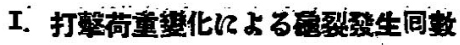

高 $C r$ 鋼(耐錆鋼) \& $N i-C r-W$

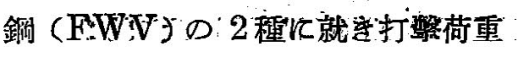

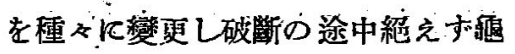
裂の發生雅浣范 $1 / 100 \mathrm{~mm}$ 迄の精度 を有する顯微揤器で檢出するとうう

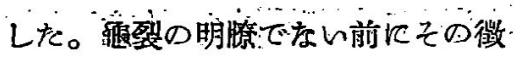
候とす自られる。尚あ發見した場合 には參考之して幑候と記した。其の

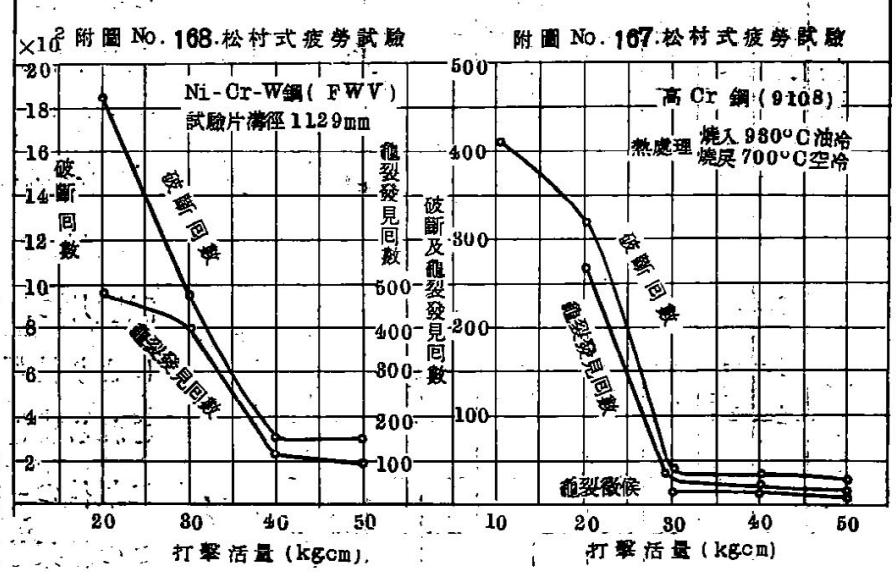

示してある。

乙の結果から高 $C r$ 鋼では很裂發生後遖に破斷 し高 $N i-C r-W(\mathrm{FWY})$ 鋼は比较的速证西裂す る破斷迄に相當司數を要す。破断面の景況は附 圖 No.169 及 No.170 中に示す樣に前者は各荷, 重共に粗粒破斷であうて中央帶部の存在を認めず 後者は中心迄率裂進行し最後の破斷部の中央帶部 の荷重の大となる每に幅の大となる狀況を見る。

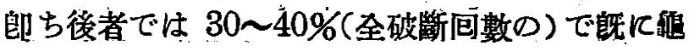
裂を生じ Grain の Slip 叉は Shear で內部迄 侵大せるは䩓性の大なる材料の特徽でする。 生が掘延する。反之大荷重の時は發生が速かであ

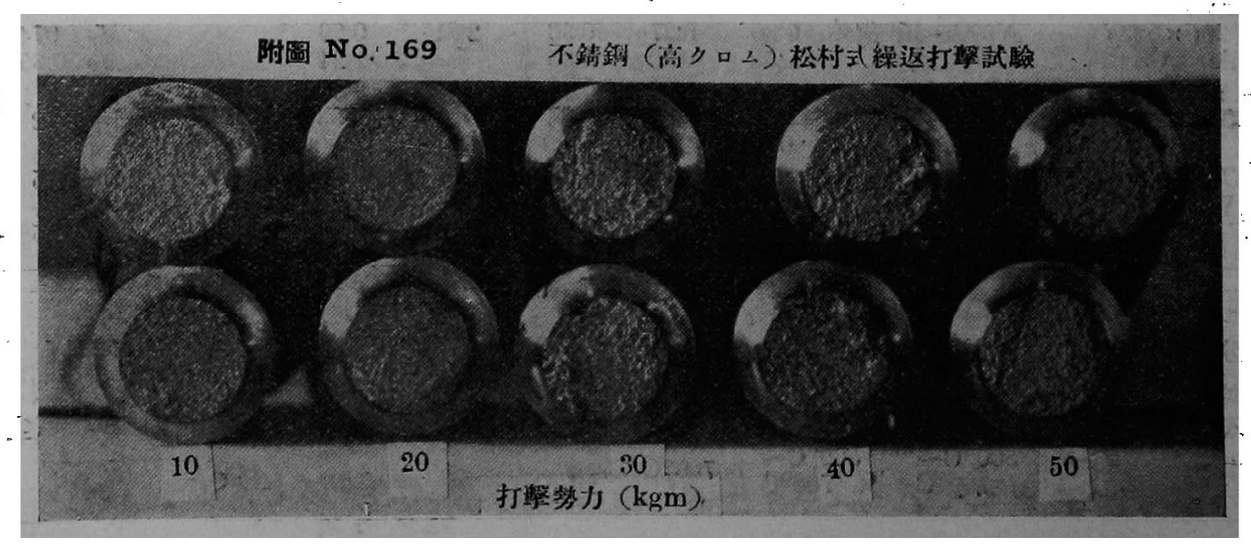




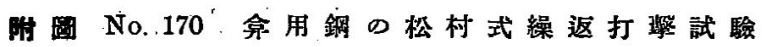

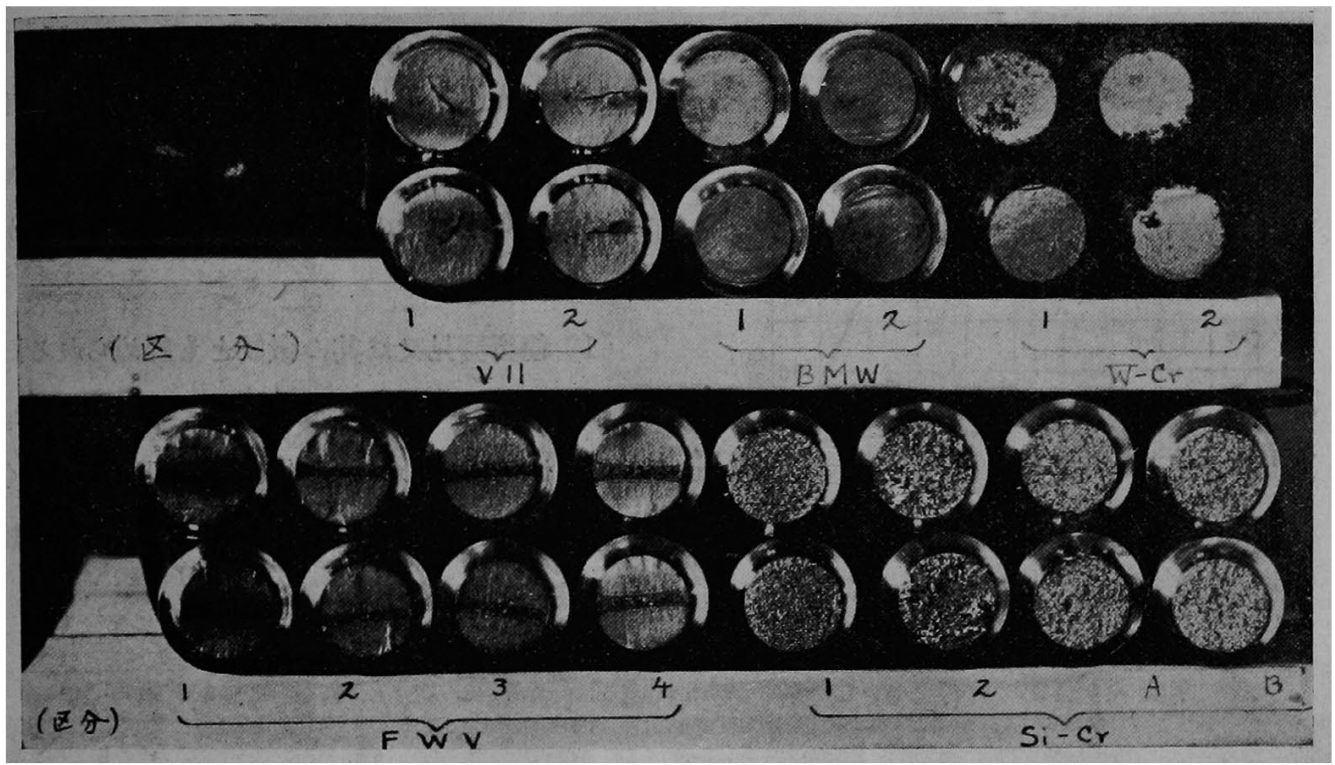

尚この兩者のブリネル硬度を比較するに何れる 210 附近でするが一方高 $C r$ 鋼の衝撃檤は 0.668

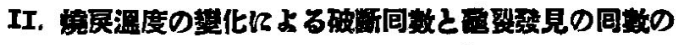
$\mathrm{kgm} / \mathrm{cm}^{2}$ で他は $10.39 \mathrm{kgm} / \mathrm{cm}^{2}$ であつて松村式间 闃係

數は衝㢣値の犬なるもの今方著しく大でする事よ

供試鋼は Bohler Anto Extra PA 銅 $(N i-C r$ り見れば斯る疲勞破斷には衝慗值の大である事は 必要の條件である事が看取される。

低炭素鏰) Bohler CS 錩 ( $\mathrm{S} i-C r$ 鋼) $\mathrm{Ni}-\mathrm{Cr}$ $M 0$ 銓 (AW 20×527) の 3 種几就て實用燒杘 溫度別に於ける破斷包數と㭊裂發見回數との關係 附圖 No.172. 松村式疲勞試验

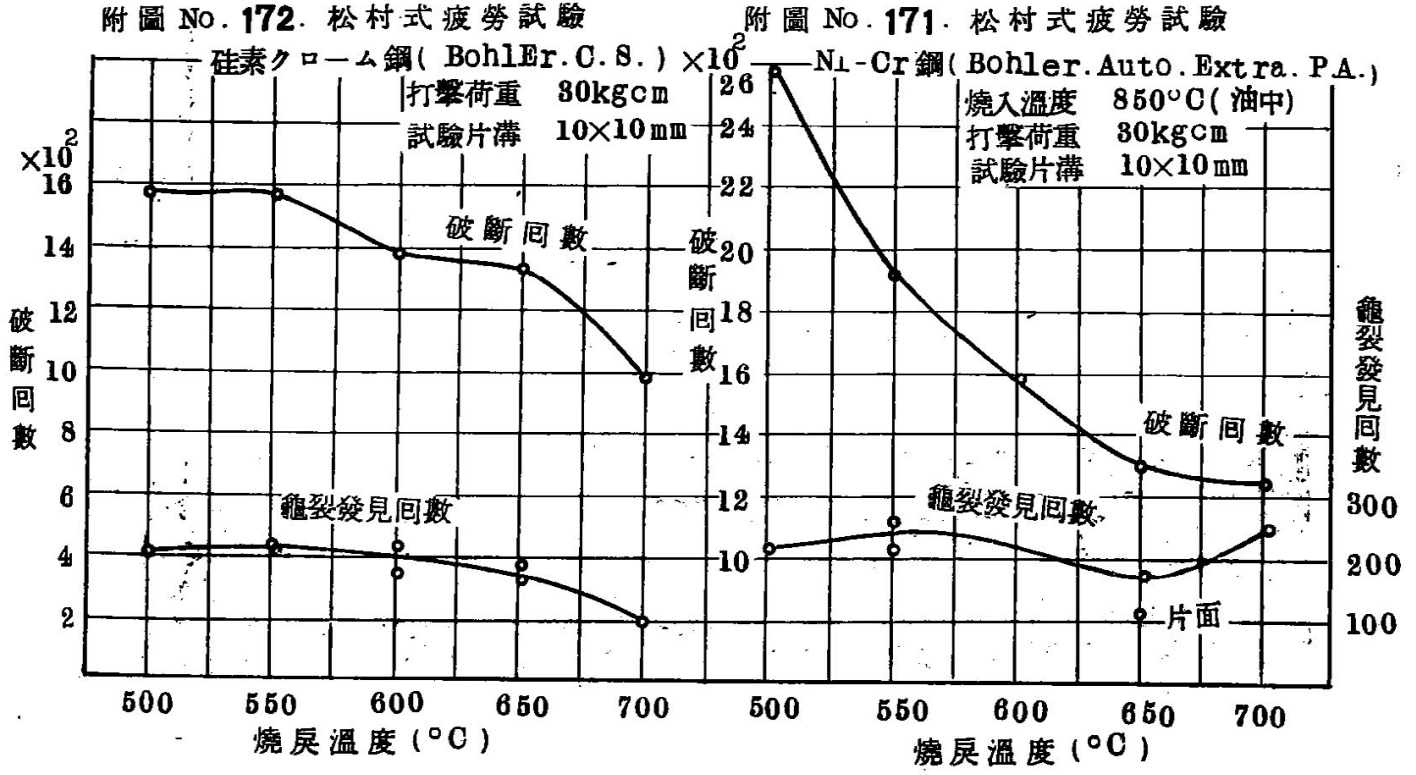




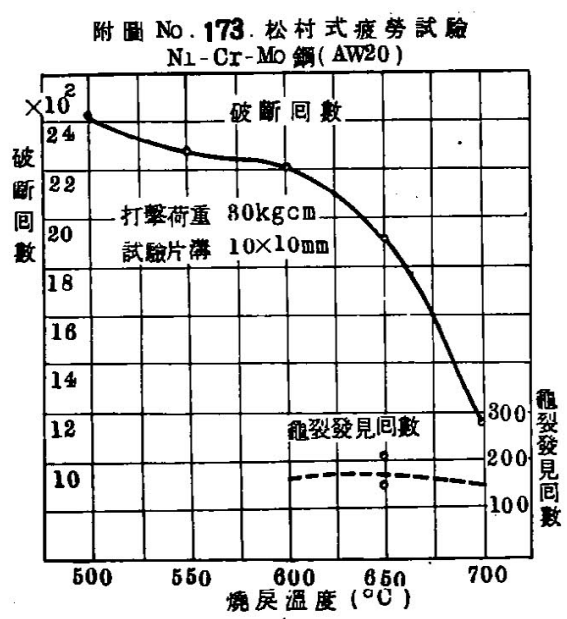

を試驗した。但し 1 间の打擊活量は $30 \mathrm{kgcm}$ と した，乙の結果は。”附圖 No.171 乃至 No.173 參照。破面の景況は附圆 No. 174 万至 No.176 に示す。

この結果から次の样な事實を摘記することが出 隶る。

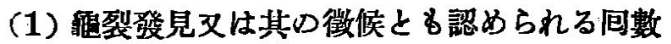
は全破断回数の $10 \%$ 附近であつて (㑲重 $30 \mathrm{kgcm}$ の時）燒戻溫度の戀化と共に破斷回數の著しく低

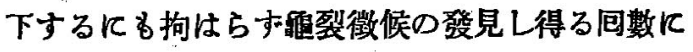
は大差はをい。
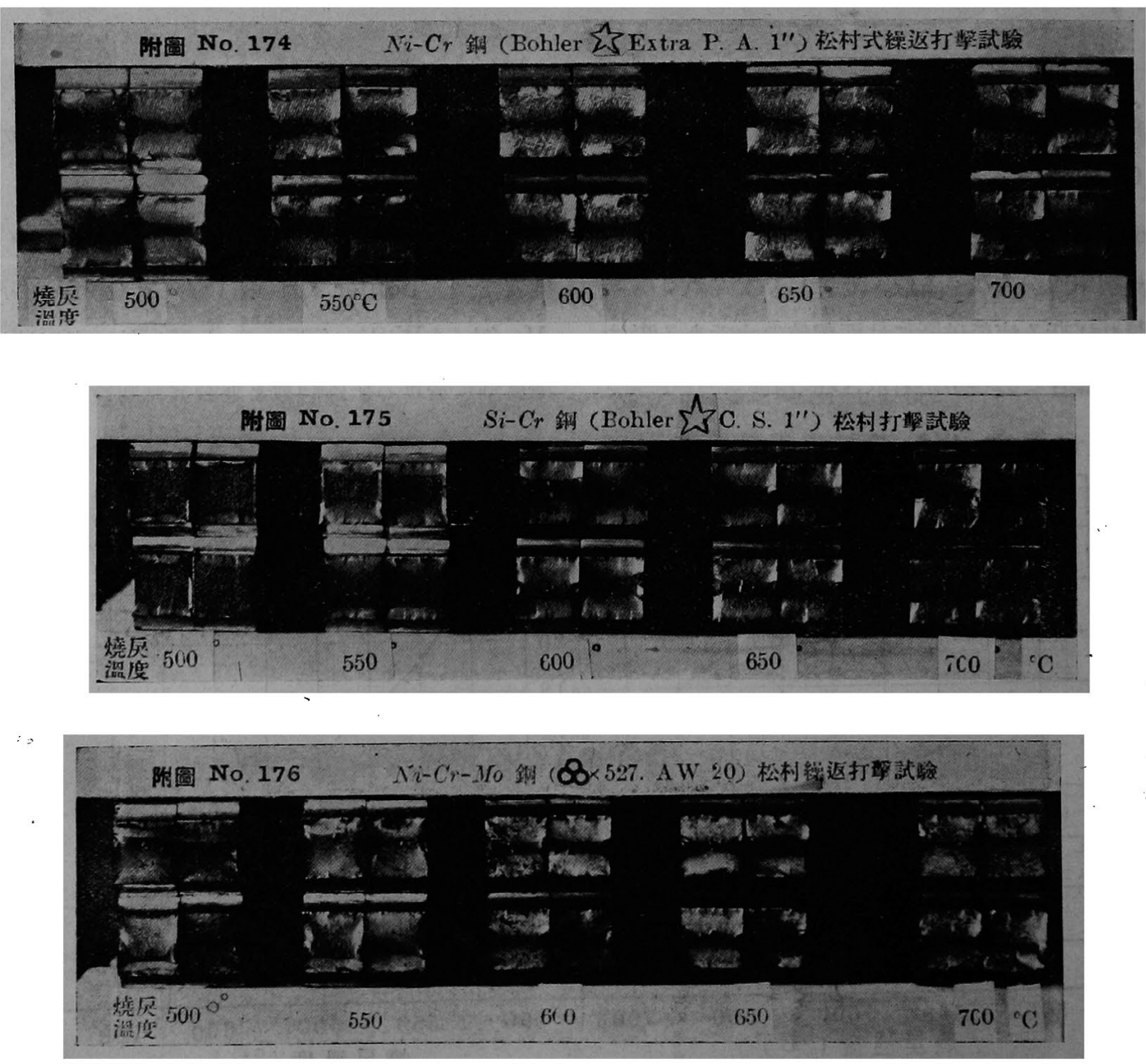


\begin{tabular}{|c|c|c|c|c|c|c|c|}
\hline 銅 種 & 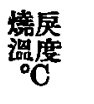 & 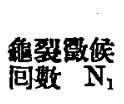 & 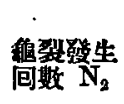 & $\begin{array}{l}\text { 肉眼に8 } \\
\text { 制明せる } \\
\text { 回软 } \mathbf{N}_{3}\end{array}$ & $\begin{array}{l}\text { 破数 } \\
\text { 數 } \\
\text { N }\end{array}$ & $\mathbf{N}_{1} / \mathbf{N} \times 100$ & $\overline{\mathrm{N}_{2} / \mathrm{N}} \times 100$ \\
\hline $\begin{array}{l}N i-C r \text { 低宸 } \\
\text { 素解 (Bohln } \\
\text { Anto Extra PA) }\end{array}$ & $\left.\begin{array}{l}500^{\circ} \mathrm{C} \\
550 \\
600 \\
650 \\
700\end{array}\right\}$ & $\begin{array}{r}\frac{155}{-} \\
\overline{160} \\
\overline{174}\end{array}$ & $\begin{array}{r}216 \\
224 \\
215 \\
258 \\
-220 \\
108 \\
222 \\
251 \\
274\end{array}$ & $\begin{array}{r}403 \\
694 \\
445 \\
498 \\
390 \\
318 \\
342 \\
450 \\
474\end{array}$ & $\begin{array}{l}2581 \\
2569 \\
1886 \\
1941 \\
1576 \\
1561 \\
1196 \\
1402 \\
1255 \\
1238\end{array}$ & $\begin{array}{l}\frac{8 \cdot 22}{1 \overline{0} \cdot 22} \\
\overline{14} \cdot 8\end{array}$ & $\begin{array}{c}8 \cdot 37 \\
8 \cdot 71 \\
11 \cdot 40 \\
13 \cdot 30 \\
-14 \cdot 1 \\
7 \cdot 03 \\
15 \cdot 80 \\
20 \cdot 0 \\
22 \cdot 1\end{array}$ \\
\hline $\begin{array}{l}S_{i}-C r \text { 鋼 } \\
(\mathrm{C}-\mathrm{S} \text { 銅) }\end{array}$ & $\left.\begin{array}{l}500^{\circ} \mathrm{C} \\
550 \\
600 \\
650 \\
700\end{array}\right\}$ & $\begin{array}{r}144 \\
154 \\
150\end{array}$ & $\begin{array}{r}\overline{207} \\
215 \\
202 \\
212 \\
172 \\
184 \\
162 \\
100 \\
94\end{array}$ & $\begin{array}{r}1299 \\
1407 \\
705 \\
592 \\
472 \\
662 \\
565 \\
462 \\
326 \\
404\end{array}$ & $\begin{array}{r}1506 \\
1641 \\
1613 \\
1520 \\
1420 \\
1318 \\
1311 \\
1347 \\
1000 \\
988\end{array}$ & $\begin{array}{r}9 \cdot 6 \\
9 \cdot 6 \\
10.3\end{array}$ & $\begin{array}{r}-\overline{12 \cdot 6} \\
13 \cdot 3 \\
13 \cdot 3 \\
14 \cdot 9 \\
13 \cdot 1 \\
14: 0 \\
12 \cdot 1 \\
10 \cdot 0 \\
9 \cdot 4\end{array}$ \\
\hline $\begin{array}{l}N i-C r-M o \\
\text { 銅 (AW 20) }\end{array}$ & $\begin{array}{l}500^{\circ} \mathrm{C} \\
550 \\
600 \\
650 \\
700\end{array}$ & $\begin{array}{r}\overline{16 \cdot 7} \\
100 \\
151\end{array}$ & $\begin{array}{l}267 \\
269 \\
150 \\
200 \\
200\end{array}$ & $\begin{array}{l}539 \\
432 \\
333 \\
350\end{array}$ & $\begin{array}{l}2347 \\
2510 \\
2217 \\
2355 \\
2184 \\
2257 \\
1977 \\
1856 \\
1197 \\
1132\end{array}$ & $\begin{array}{r}\overline{74} \\
\\
8 \cdot 2 \\
13 \cdot 4\end{array}$ & $\begin{array}{r}11 \cdot 81 \\
10 \cdot 6 \\
8 \cdot 1 \\
16 \cdot 7 \\
17 \cdot 7\end{array}$ \\
\hline
\end{tabular}

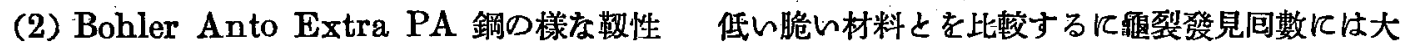
の大きな鋼と Bohler CS 鋼の樣な相當衝擊傎の 差なをる破斷回數に於て差が大きい。この原因は

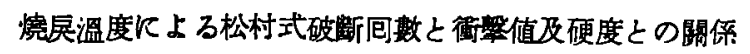

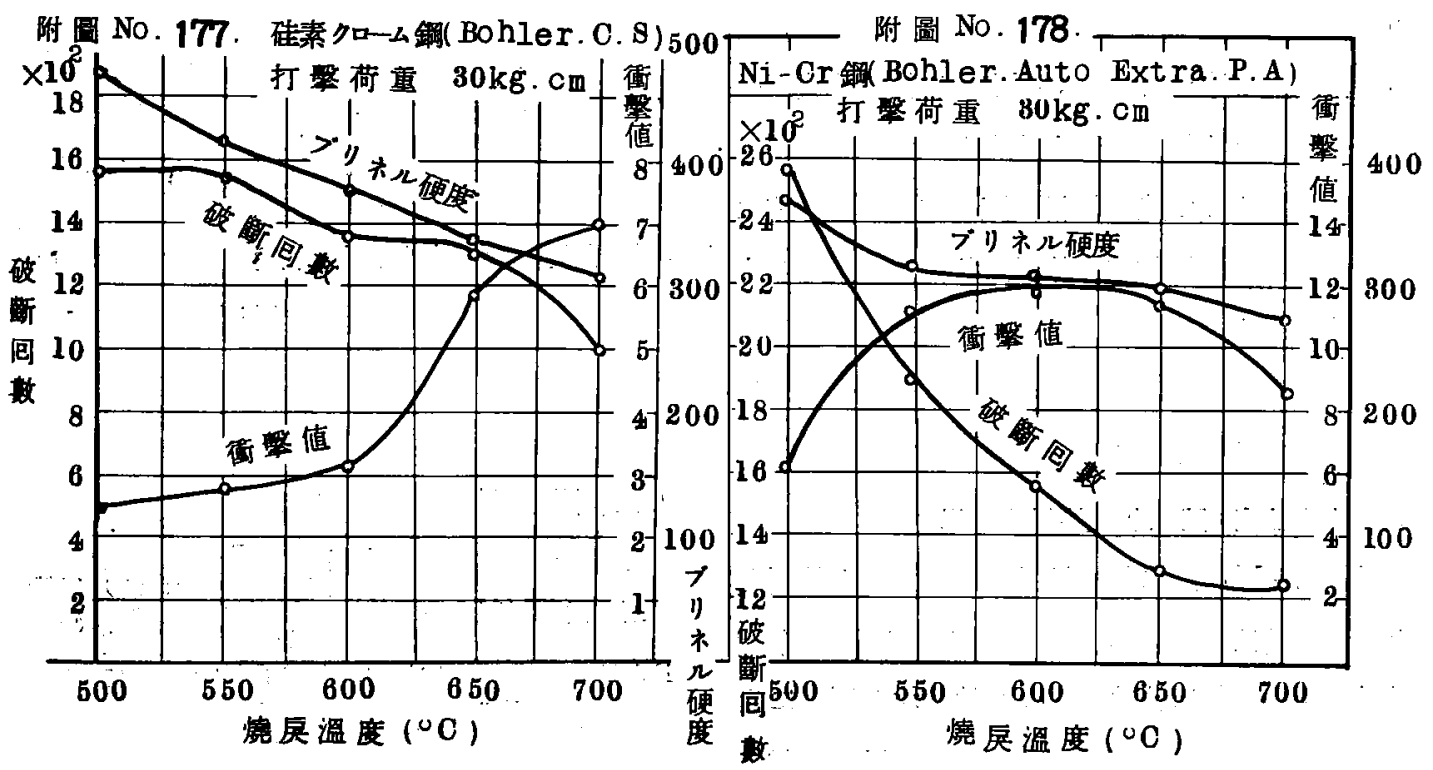


舅裂が內部に侵入する速度と深さに關係を有する 䉆めで䩒性の多し前者は耐久力は大である。雨者 を比较すれば次の通りとす。之等鋼の燒杘㴧度別 による衝撃值と松村式破斷回數との 關係は附圖 No.177 及 No.178 に示す。

\begin{tabular}{|c|c|c|c|c|}
\hline 鋼 & 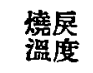 & $\begin{array}{l}\text { 衝㹂值 } \\
k g m c m^{2}\end{array}$ & $\begin{array}{l}\text { ブリネ } \\
\text { ル硬度 }\end{array}$ & $\begin{array}{l}\text { 松村式 } \\
\text { 破断包數 }\end{array}$ \\
\hline $\begin{array}{l}\text { Bohler } \\
\text { Anto Extra } \\
\text { PA } \\
\text { ( } N_{i} C r \text { 銅) }\end{array}$ & $\left\{\begin{array}{l}500^{\circ} \mathrm{C} \\
550 \\
600 \\
650 \\
700\end{array}\right.$ & $\begin{array}{r}6.28 \\
11.06 \\
11.99 \\
11.46 \\
8.60\end{array}$ & $\begin{array}{l}370 \\
313 \\
306 \\
298 \\
275\end{array}$ & $\begin{array}{l}2575 \\
1914 \\
1569 \\
1299 \\
1247\end{array}$ \\
\hline $\begin{array}{l}\text { Bohler } \\
\text { Si-C } \text { 除 } \\
\text { (CS 鋮) }\end{array}$ & $\left\{\begin{array}{l}500^{\circ} \mathrm{C} \\
550 \\
600 \\
650 \\
700\end{array}\right.$ & $\begin{array}{l}256 \\
283 \\
3 \cdot 19 \\
5 \cdot 93 \\
6 \cdot 96\end{array}$ & $\begin{array}{l}470 \\
418 \\
381 \\
337 \\
311\end{array}$ & $\begin{array}{r}1574 \\
1567 \\
1369 \\
1329 \\
994\end{array}$ \\
\hline
\end{tabular}

郎ち硬度同しく衝熬值の異る場合 (PA 鋼の $550^{\circ} \mathrm{C}$ 燒戻では衝撃値 $11.06 \mathrm{CS}$ 鋼の $700^{\circ} \mathrm{C}$ 燒厌の場合注衝擊值 6.96）方比較するに松村式 问數は著しく PA 鋼大で 1914 亿對し CS 鋼は 994 である。

（3）一般に松村式旬數は硬度にのみ支配されす

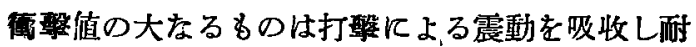
久疲勞の點では破斷迄の生命は長い。但し局部の 酎久限界郎ち分離破断の惹起する迄の耐久性には 餘り差のない事が知れる。要するに松村式疲勞試 驗では鬼裂發生後その進入速度と樑さによつて耐・ 久性が定るるので脆い材料は梁さが大ならす速に 破斷する。反之衝撃值、伸斷面收樎來の大なるも のは倚重の小なる間は一時に破斷には到らない。 ての意味にて低炭素 $N i-C r-W$ 鋼 (タハード鎆 の如き)は秀れてねる。

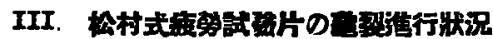

$\mathrm{Ni}-\mathrm{Cr}-\mathrm{Mo}$ 鋼に就き烃村式破斷回數と臽裂發 生迄の司數は附圖 No.179 К示してある。今燒

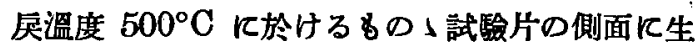
じた䑾裂は約 1,700 回附近で認かた。以啳打㡂の

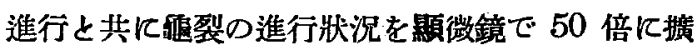
大して A.B 兩淊裂を曲線に取つて見る時岋附圖 No.180 に示す。側面维裂の進行は溝底面に或る 角度をなし概ね $70^{\circ} \sim 80^{\circ}$ 範圍である。脆い狀態 のるのは角度は直角近くなる傾向に在る。且つ進 行速度は速かでなく其進入の深さは小である。
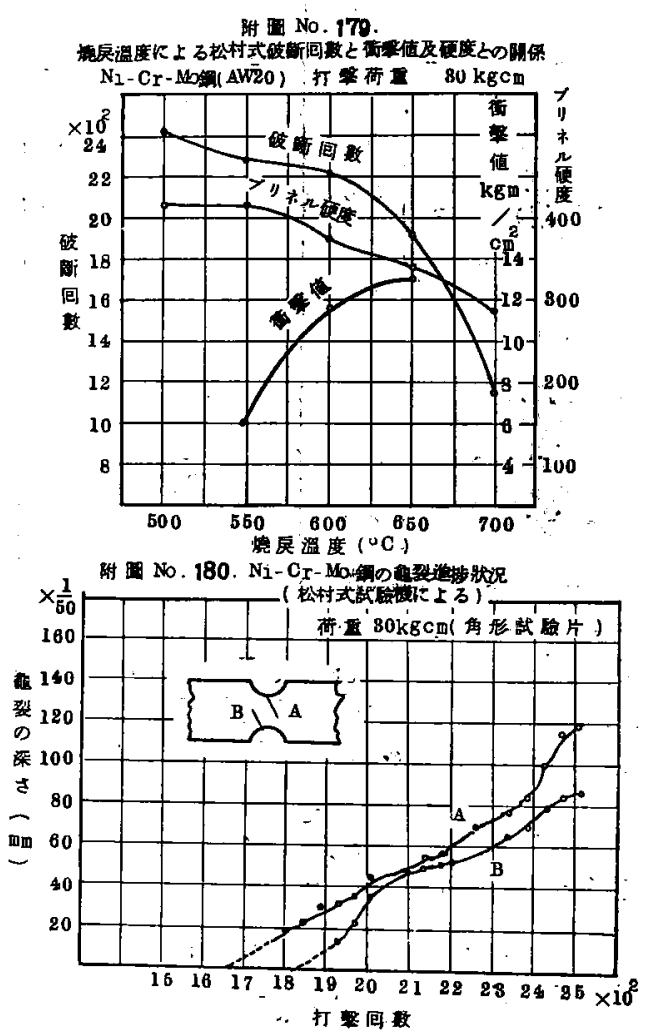

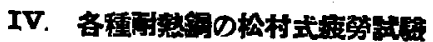

次に示す樣な各種發動機排集拿用龬として從來 使用せられた材料に就き同樣松村式疲娈試驗を行 つた結果次の成樍を得た。打繁荷重は $30 \mathrm{kgcm}$ と した。附圆 No.170 寥照。

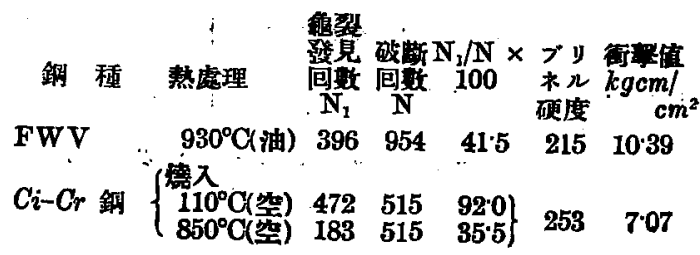




\begin{tabular}{|c|c|c|c|c|c|c|}
\hline " & $\left\{\begin{array}{l}\prime \prime \\
900^{\circ} \mathrm{C} \text { (空) }\end{array}\right.$ & $\begin{array}{l}236 \\
209\end{array}$ & $\begin{array}{l}\mathbf{4 2 7} \\
\mathbf{3} 34\end{array}$ & $\begin{array}{l}55^{\prime 2} \\
62^{\prime} 6\end{array}$ & & \\
\hline 高 $C-C r$ 䤡 & $800^{\circ} \mathrm{C}$ (空) & & 38 & & 296 & 0.89 \\
\hline VII & $1,1 \mathrm{CO} 0^{\circ} \mathrm{C}$ (空) & $\left\{\begin{array}{l}107 \\
261\end{array}\right.$ & $\begin{array}{l}293 \\
464\end{array}$ & $\left.\begin{array}{l}36 \cdot 1 \\
56 \cdot 5\end{array}\right\}$ & 249 & $2 \cdot 13$ \\
\hline W-Cr 銅 & $\left\{\begin{array}{l}950^{\circ} \mathrm{C} \\
660^{\circ} \mathrm{C}(\mathrm{cc})\end{array}\right.$ & $\begin{array}{r}59 \\
-99\end{array}$ & $\begin{array}{l}173 \\
169\end{array}$ & $\begin{array}{l}34 \cdot 1 \\
58 \cdot 5\end{array}$ & $\begin{array}{l}249 \\
488\end{array}$ & $\begin{array}{l}2.13 \\
1.55\end{array}$ \\
\hline$C_{0}-C_{r}$ 鋮 & 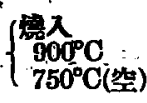 & & 297 & & 323 & 1.90 \\
\hline " & $780^{\circ} \mathrm{C}$ (空) & & 266 & & 252 & 184 \\
\hline
\end{tabular}

之結果を見れば松村式间數は單にブリネル硬度 に比例せす明に衝摮值にる關係を有することが分 る。FWV の如き硬度低く共衝繁檤高きるのは 破斷迄の间數大で高炭素クロム鋼の樣な脆いるの は破斷回數極めて低い。尚硬度の著しく高ん $W-$ $C r$ 鋼の如きは的裂の發生も速かで破歁回數子低 い事は衝擊值の低レととに基因するるのと考へら れる。(但し本試驗の打盤回數は $30 \mathrm{kgcm}$ であつ ててれより小さな荷重では趣を異にするやも知れ 才。但し例外あるる大體松村式破斷间數はブリネ 几硬度と破斷包數の\% 30\% 附近上り現出するる のもあるが脆いるのは夫以後進入する深さ少く。 全々中央帶部の無くなるが幅は著しく廣くなる。

其 2. Amsler Universal Hammer Machine 飞よる疲勞試驗

本試擥機怯 Amsler 會社製 Univiversal Hammer Machine と粚し右上圖に示す樣な構造で其 の機能及び負荷要領は次に亦す樣に 3 種に區分さ れ繰返し屈撓、繰返し抗張及び繰返し抗涯の耐久 力を求めるるので附圖の試驗片は繰返し屈撓の場 合である。乙の場合では衝撃屈撓で橫に间轉中の 試驗片 (1. 分間 6 回轎)を槌を以て其の中央を 1

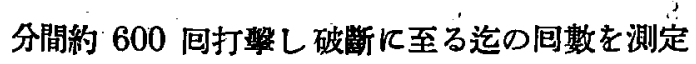
ナるのである。
I. 機能計 算

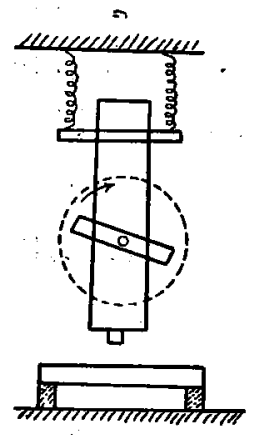

槌の靜力量と動力量の關係。

(1) $\mathrm{G}=\mathrm{mg} \cdot \cdots$ 榊の重量下 方に働く

$\mathrm{R}$ (發條の力) は最高壓縮 位置の最大值

$\mathrm{R}_{0}$ 加ら直線的に低下 ᄂ Rm 飞達す

(2) $R=R_{0}-\frac{R_{0}-R m}{r} \quad R=R_{0}-K y$

$\mathrm{K}:$ 發條の彈性係数

$\mathrm{y}:$ 槌の最高位置からの衝程

$\mathbf{r}$ :曲軸肱により描かれる圆牛徑

$\mathrm{N}$ : 曲軸肱轉子の垂直壓力、之柱槌の橫軸承 に受ける力で下方に衔く D'Alembertsの原 理で各僢間の靜力量と慣性力 $\mathrm{T}$ とは本衝する

(3) $T=-m \frac{d^{2} V}{d t^{2}}$

(4) $\mathrm{G}+\mathrm{R}-\mathrm{N}+\mathrm{T}=0$

(5) $y=r(1-\operatorname{cosw} t) \quad$ 但 $L w=$ 曲軸肱の角速 度

$\frac{d y}{d t}=r w \sin w t$ $\frac{d^{2} y}{d t^{2}}=r w^{2} \cos w t$

(6) $\mathrm{N}=\mathrm{mg}+\mathrm{R}_{0}-\mathrm{Kr}(1-\cos \mathrm{wt})-\mathrm{mrw}^{2}$ $\cos w t$ $=\mathrm{mg}+\left(\mathrm{R}_{0}-\mathrm{Kr}\right)-\left(\mathrm{mr} \mathrm{w}^{2}-\mathrm{Kr}\right) \cos \mathrm{wt}$ 䅔が一定の運轉を續ける場合には N>00るる要 す。

若L $\cos w t=1 \quad w t=0$

(7) $\mathrm{mg}+\left(\mathrm{R}_{0}-\mathrm{Kr}\right)-\left(\mathrm{mrw}^{\mathrm{z}}-\mathrm{Kr}\right)>0$. 


$$
\mathrm{w}^{2}<\frac{\mathrm{mg}+\mathrm{R}_{0}}{\mathrm{mr}}
$$

本式は棺の重量、發條の初張力、曲軸肱の牛徑 及回轉數の關係を示し、ての條件は回轉数最大郎 ち $\mathrm{r}$ の最大の時に霃足すると过ば $\mathrm{w}$ 及 $\mathrm{r}$ の之 以下の時にも成立する、此式から發條の初張力に は關係あるる彈性係數には關係ない。

棜仕試驗片几與一る勢力。

槌の有效勢力郎ち曲軸肱に上り描かれる圆の水 平遖徑を通過する際に次次の通り。

(8)

$$
\begin{aligned}
& \mathrm{A}(\text { 勢力 })=\int_{y=0}^{y=r}(\mathrm{G}+\mathrm{R}-\mathrm{N}) \mathrm{dy} \\
& \mathrm{G}+\mathrm{R}-\mathrm{N}=-\mathrm{T}=-\left(-\mathrm{m} \frac{\mathrm{d}^{2} \mathrm{y}}{\mathrm{dt}^{2}}\right) \\
& \begin{aligned}
\mathrm{A} & =\int_{y=0}^{y=r} \frac{\mathrm{d}^{2} \mathrm{y}}{\mathrm{dt}^{2}} \mathrm{dy}=\int_{y=0}^{y=r} \frac{\mathrm{d}^{2} \mathrm{y}}{\mathrm{dt}^{2}} \cdot \frac{\mathrm{dy}}{\mathrm{dt}} \cdot \mathrm{dt} \\
& =\int_{y=0}^{\nu=r} \frac{\mathrm{d}}{\mathrm{dt}}\left(\frac{1}{2} \mathrm{~m}\left(\frac{\mathrm{dy}}{\mathrm{ds}}\right)^{2}\right) \mathrm{dt} \\
& =\left[\frac{1}{2} \mathrm{~m}\left(\frac{\mathrm{dy}}{\mathrm{dt}}\right)^{2}\right]_{y=0}^{y=r}
\end{aligned}
\end{aligned}
$$

$\mathrm{y}=0$ (捾の最高位置)の點では $\frac{\mathrm{dy}}{\mathrm{dt}}=0$ (重直

\section{速度）}

$\mathrm{y}=\mathrm{r}$ に於ける槌の垂直速度は曲軸肱の圆周 速度に等しく $\frac{d y}{d t}=u$
從つて運動勢力の定理に從へば

$$
\begin{aligned}
\mathrm{m}=\frac{\mathrm{G}}{\mathrm{g}} \quad \mathrm{u}=\mathrm{wr}=\frac{\pi \mathrm{nr}}{30} \\
\mathrm{~A}=\frac{1}{2} \cdot \frac{\mathrm{G}}{\mathrm{g}}\left(\frac{\pi \dot{\mathrm{n}}}{30}\right)^{2} \mathrm{r}^{2}=\frac{5 \cdot 5893}{10^{6}} . \\
\mathrm{G} \cdot \mathrm{n}^{2} \cdot \mathrm{r}^{2} \mathrm{kgcm} / \mathrm{stroke}
\end{aligned}
$$

本試驗機では槌の重量 $\mathrm{G}=3.43 \mathrm{~kg}$ 回轉數

$$
\mathrm{n} \fallingdotseq 300 \text { r.p.m. }
$$

曲泚脄牛徑 $\mathrm{r}=2 \mathrm{~cm}$ 有效勢力 $\mathrm{A} \fallingdotseq 7 \mathrm{kgrm}$

$$
\begin{aligned}
& =3 \quad \fallingdotseq 16 \text {. } \\
& =4 \quad \fallingdotseq 28 \text { " } \\
& =5 \quad \fallingdotseq 44
\end{aligned}
$$

\begin{tabular}{|c|c|c|c|c|c|c|c|c|c|}
\hline \multirow{2}{*}{ 銅 種 } & \multirow{2}{*}{ 區 分 } & \multicolumn{7}{|c|}{ 分 析 成 分 } & \multirow[b]{2}{*}{ 他 } \\
\hline & & C & $S i$ & $M n$ & $P$ & $S$ & $C r$ & 其 & \\
\hline Cr 銅 & $\begin{array}{l}\mathbf{N} \\
\mathbf{D}\end{array}$ & $\begin{array}{l}0.45 \\
0.43\end{array}$ & $\begin{array}{l}0.28 \\
0.35\end{array}$ & $\begin{array}{l}0.54 \\
0.45\end{array}$ & $\begin{array}{l}0.010 \\
0.016\end{array}$ & $\begin{array}{l}0.013 \\
0: 017\end{array}$ & $\begin{array}{l}1 \cdot 76 \\
1 \cdot 63\end{array}$ & & \\
\hline "I & $\begin{array}{l}\mathbf{Y}_{1} \\
\mathbf{Y}_{2} \\
\mathbf{K}\end{array}$ & $\begin{array}{l}0.35 \\
0.45 \\
0.36\end{array}$ & $\begin{array}{l}0 \cdot 20 \\
0 \cdot 26 \\
0.33\end{array}$ & $\begin{array}{l}0.37 \\
0.41 \\
0.53\end{array}$ & $\begin{array}{l}0.011 \\
0.013 \\
0.023\end{array}$ & $\begin{array}{l}0.016 \\
0.012 \\
0.011\end{array}$ & $\begin{array}{l}1.85 \\
219 \\
1.66\end{array}$ & & \\
\hline 格 & & $0.40 \sim 0.50$ & $0.20 \sim 0.50$ & $0.30 \sim 0.80$ & 0.03以下 & 0.03以下 & $1 \cdot 50 \sim 2 \cdot 20$ & & \\
\hline $\mathrm{Ni}-\mathrm{Cr}$ 鍼 & $100 \mathrm{NC}$ & 0.29 & 0.18 & 0.38 & 0.018 & 0.011 & 1.29 & $\left\{\begin{array}{l}N i \\
M o \\
W\end{array}\right.$ & $\begin{array}{l}3.22 \\
0.42 \\
0.37\end{array}$ \\
\hline $\mathrm{Ni}-\mathrm{Cr}-\mathrm{HIo}$ 銀 & CN12 & 0.28 & $0 \cdot 21$ & $0 \cdot 18$ & 0.014 & 0.021 & $3 \cdot 13$ & $\left\{\begin{array}{l}N i \\
M O\end{array}\right.$ & $\begin{array}{l}2.83 \\
0.42\end{array}$ \\
\hline
\end{tabular}

(計算の 1 例)

$$
A=\frac{1}{2} \cdot \frac{G}{g} \cdot\left(\frac{\pi n}{30}\right)^{2} r^{2}
$$

$$
\begin{aligned}
\mathrm{r} & =2 \text { の特は } \mathrm{A}=\frac{1}{2} \cdot \frac{3 \cdot 43}{980} \cdot \frac{3 \cdot 14 \times 300}{30} \cdot 2^{2} \\
& \fallingdotseq 7 \cdot 0 \mathrm{kgcm}
\end{aligned}
$$

\section{II. 試 醶 結 果}

試驗に供した銅は次の 3 種の特殊鋼で特に $C r$ 銓は電氣㠊製として指定されたるのでN.D.Y.K は製鋼所别のものである。

\section{(a) 分析成 績}

$C r$ 鋼Ф分析結果を㾔分别飞 對照すすれ ば附圖 No.181 飞示す。之による時は $\mathrm{Y}_{1}, \mathrm{~K}$ とは $C$ 量 低く、 $\mathrm{Y}_{1} ， \mathrm{Y}_{2}$ 共傮 $\mathrm{Cr}$. 鋼稍大である。何れる製 


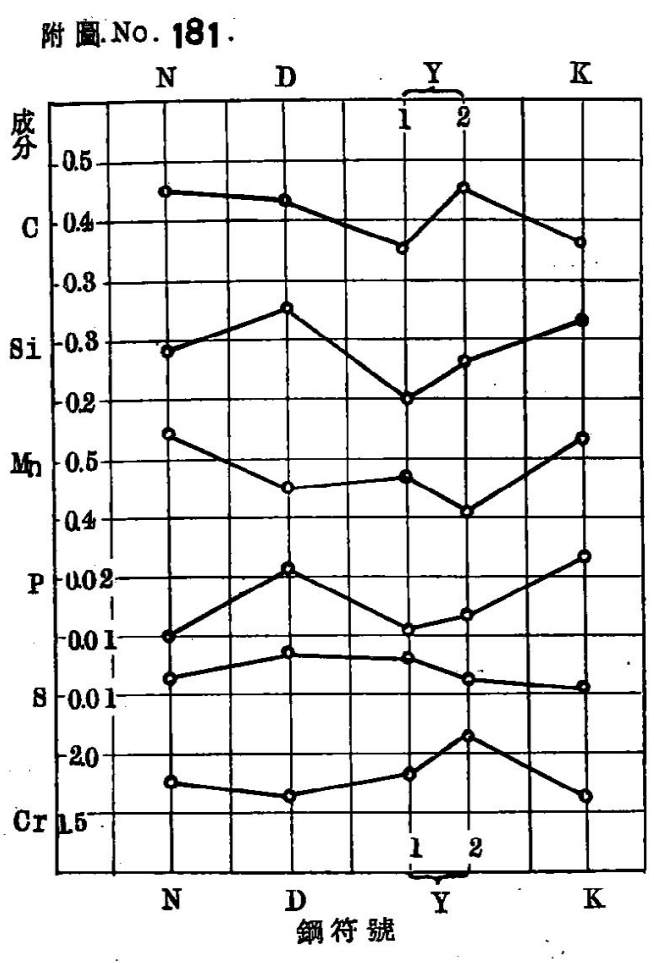

明圖 No. 183

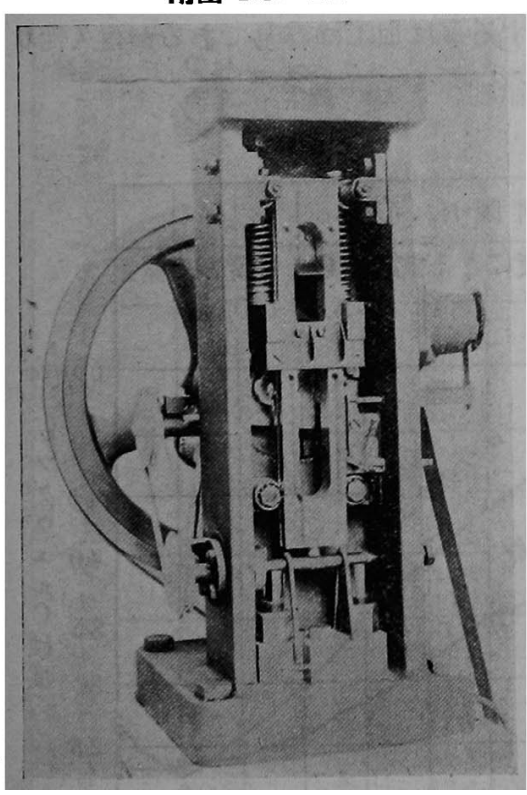

鋼洗に於て

最㥍重なる

注意を拂つ

たものであ

つて成分に

於て子大差

はない。

$N i-C_{r}$

銅注成分で

示寸核に所

謂 $100 \mathrm{~kg}$

$\mathrm{Ni}-\mathrm{Cr}$ 鋼

である、ヌ

$N i-C r-M o$ 鋼は佛國 Jacob Holzer 會社製 $\mathrm{CN}$ 12 鋼であつて何れる坩堝銅である。
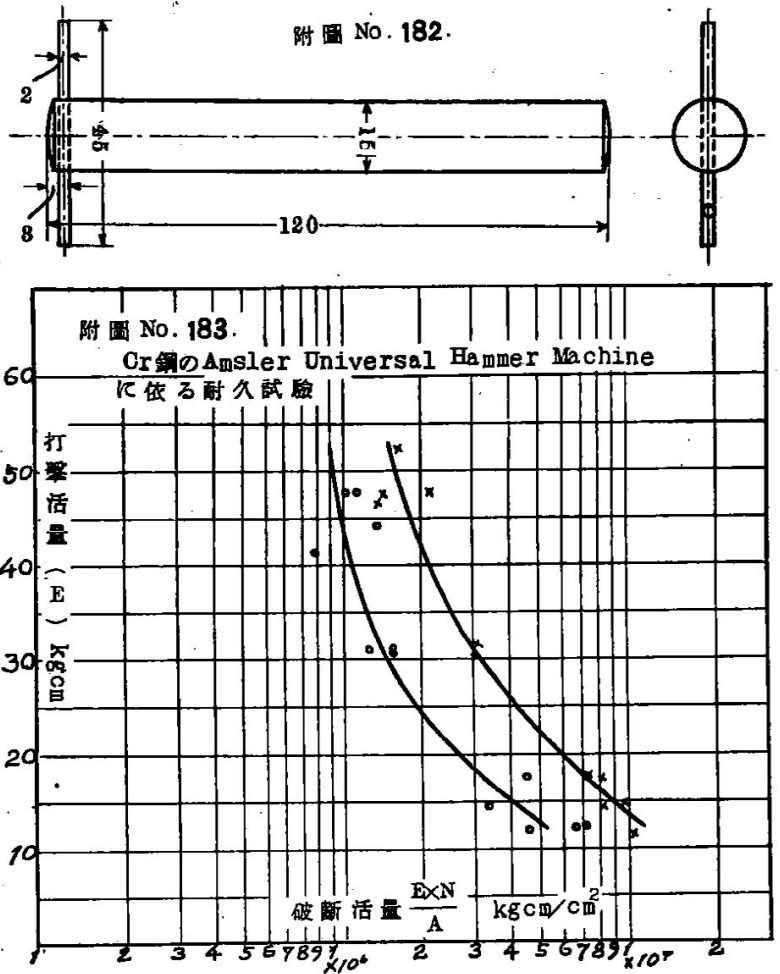

（b） $C r$ 鋼の打盤力の變化による耐久力の影響 今上記 $\mathrm{D}$ 鋼に就を次飞示す A.B 熱處理老施 した試驗片(附圖 No.182) に種々の打繋荷重(口 ーラーの $\mathbf{r}$ を變更)を加ふる事によつて破斷に至 る迄の间數を測定した。

$\mathrm{A}$. 燒入溫度 $850^{\circ} \mathrm{C}$ 燒戻溫度 $700^{\circ} \mathrm{C}$ (油中)

B. " " $600^{\circ} \mathrm{C}$ (油中)

但打媻活量はI項に示す通り次の式から計算した

$$
\mathrm{E}=\frac{5 \cdot 5893}{10^{6}} \cdot \mathrm{G} \cdot \mathrm{n}^{2} \cdot \mathrm{r}^{2} \mathrm{kgcm} / \mathrm{stroke}
$$

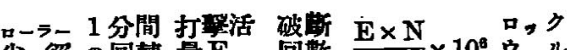

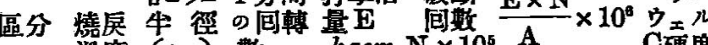
䍙度 $(\mathrm{cm})$ 数 $\mathrm{kgcm} \mathrm{N} \times 10^{5} \mathrm{~A} \times$ C硬度

D (1) $700^{\circ} \mathrm{C} \quad 5 \quad\left\{\begin{array}{lllll}315 & 47 \cdot 60 & 0.4481 & 1.209 & 27 \cdot 7\end{array}\right.$

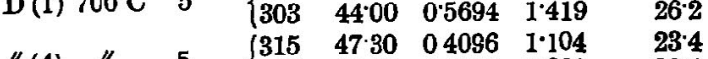

"(4) " $5 \quad \begin{array}{llllll}3293 & 41 \cdot 30 & 0.3802 & 0.890 & 22 \cdot 4 \\ \end{array}$

$\begin{array}{llllll}11 & 1\end{array} \quad \begin{array}{lllll}317 & 30.94 & 0.9199 & 1.611 & 24.7\end{array}$

$4 \quad \begin{array}{lllll}315 & 30.53 & 0.9320 & 1 \cdot 612 & 25 \cdot 2\end{array}$

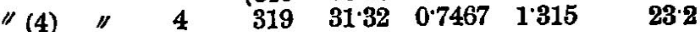

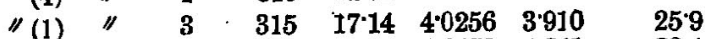

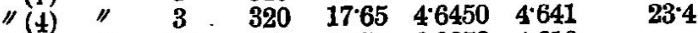

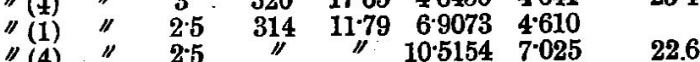


打擊活量 $\mathrm{E}$ と $(\mathrm{E} \times \mathrm{N}) / \mathrm{A}$ ( $\mathrm{A}$ は斷面積) との 關係を曲線に示せば附圖 No.183の如くなる。こ の範圍の $\mathrm{E}$ と $(\mathrm{E} \times \mathrm{N}) / \mathrm{A}$ との關係は大體次の 實驗式で示される。

$$
\mathrm{E} \times \log \left(\frac{\mathrm{E} \times \mathrm{N}}{\mathrm{A}}\right)=50 \times 10^{6}
$$

倘 $600^{\circ} \mathrm{C}$ 燒戻の場合は次の表に示す通りであ る。

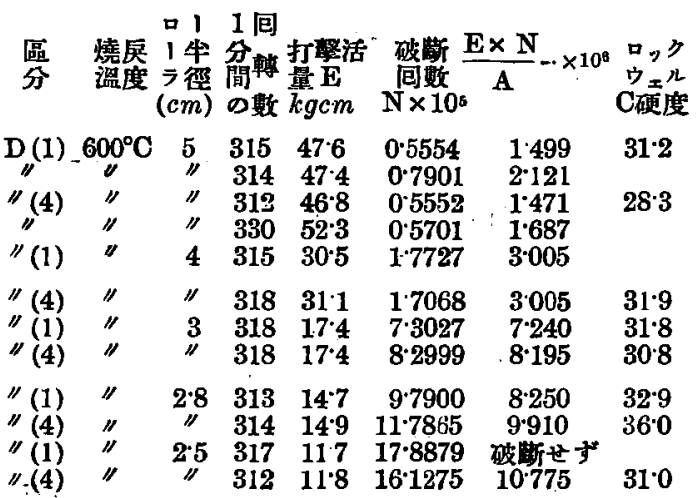

ての結果を曲線に示す時は附圖 No. 183 の樣 であつて關係式は次に示す事が出來る。

$\mathrm{E} \times \log \left(\frac{\mathrm{E} \times \mathrm{N}}{\mathrm{A}}\right)=100 \times 10^{6}$
以上の結果から $700^{\circ} \mathrm{C}$ 燒戻の場合の耐久限界 は $\mathrm{r}=2.5 \mathrm{~cm}$ 以下の打繁活量にあるる $600^{\circ} \mathrm{C}$ 燒 㞔の場合には 1 個の試驗片は $\mathrm{r}=2.5 \mathrm{~cm}$.に於て $16 \times 10^{6}$ にて折斷したが他の 1 個は $1^{\circ} 79 \times 10^{6}$ 间です折斷しないてとから見れば此場合の耐久限 界は $2.5 \mathrm{~cm}$ 上り僅に小何重にあるるのと考人

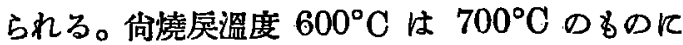
對して著しく耐久力大である事は抗張力硬度の量 に耐久力は此例してるる事を知る。

(c) 燒戻溫度による $C r$ 鋼の耐久力比较

前記 $\mathrm{D}$ 鋼及 $\mathrm{K}$ 鋼の 2 種に就を燒入後燒戻溫 度 $300^{\circ} \mathrm{C}$ 乃至 $750^{\circ} \mathrm{C}$ 迄變化して破斷迄の回数 を測定した。但しローラーの $\mathrm{r}=5 \mathrm{~cm}$ とした。其 結果は次の通りであつて附圖 No.184 及 No.185 にはての關係を示す。

この兩種鋼共に耐久力は燒戻溫度と共に低下し ロツクウェル硬度に反比例し郎ら燒戻溫度 $650^{\circ}$ 以上で使用する事は加工注容易であるが耐久性は 最劣る事を知る。

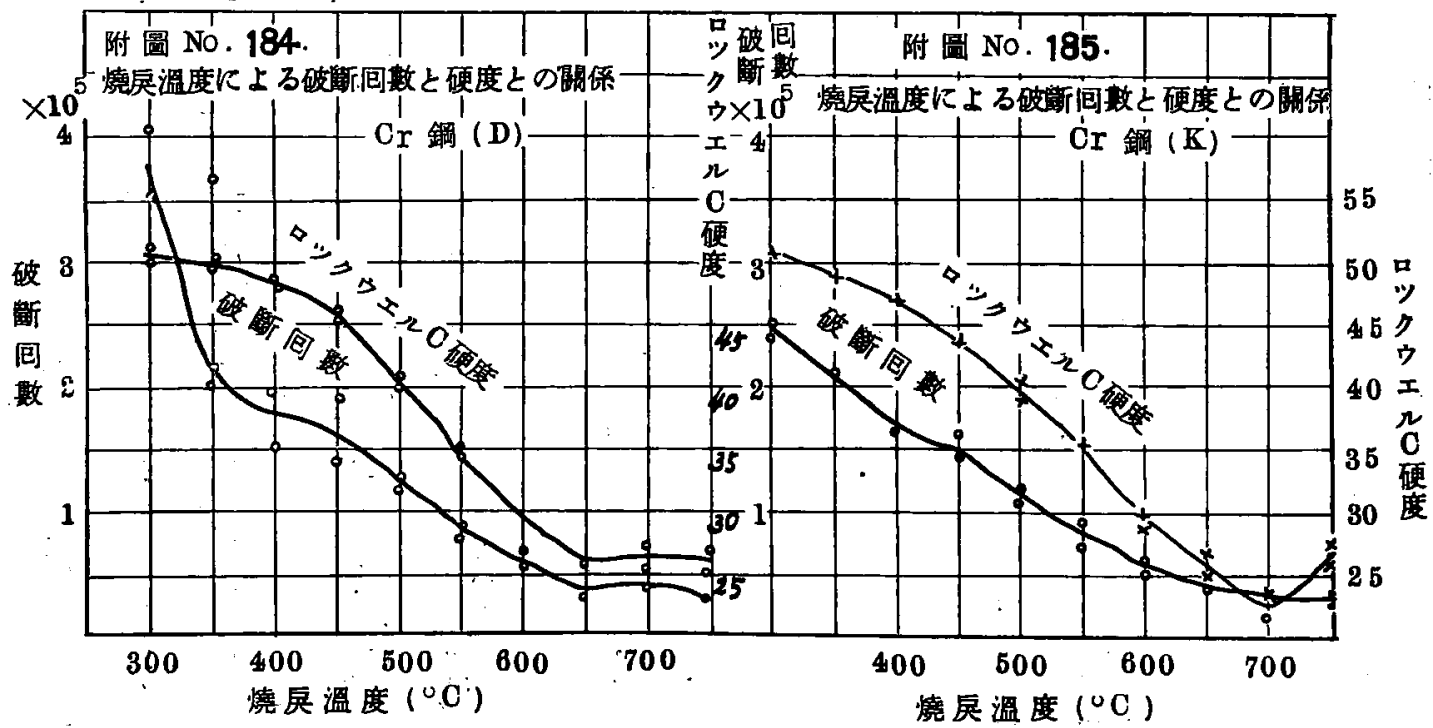




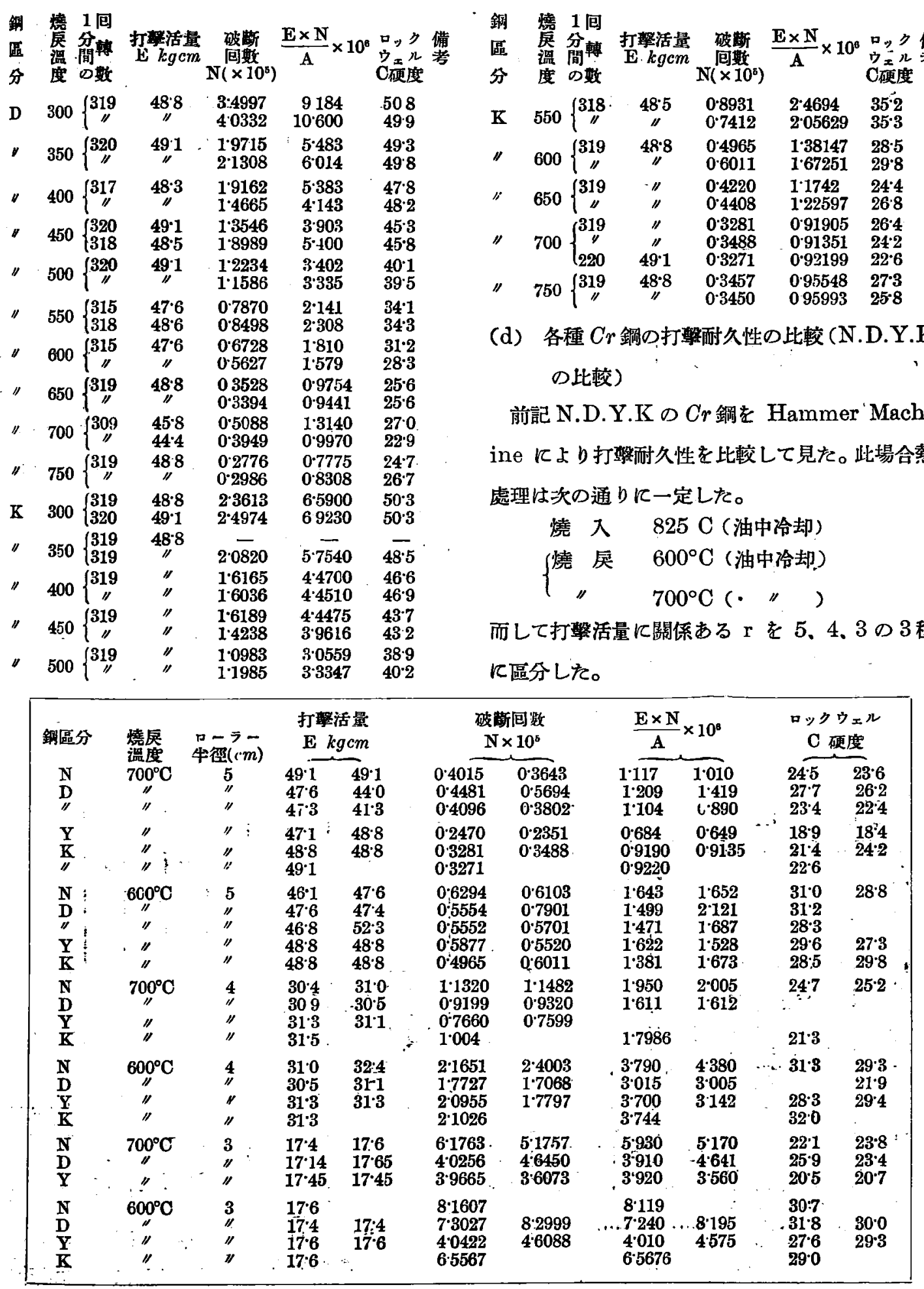


।

附圆 No. 187. 各種 $\mathrm{Cr}$ 堸（NDYK）の酎久力比較

附圖 No. 186.．各種Or 鋼( NUYK) の耐久力比較 耐久試驗 焼戻 $600^{\circ} \mathrm{C} \quad \mathrm{r}=5 \mathrm{~cm}$

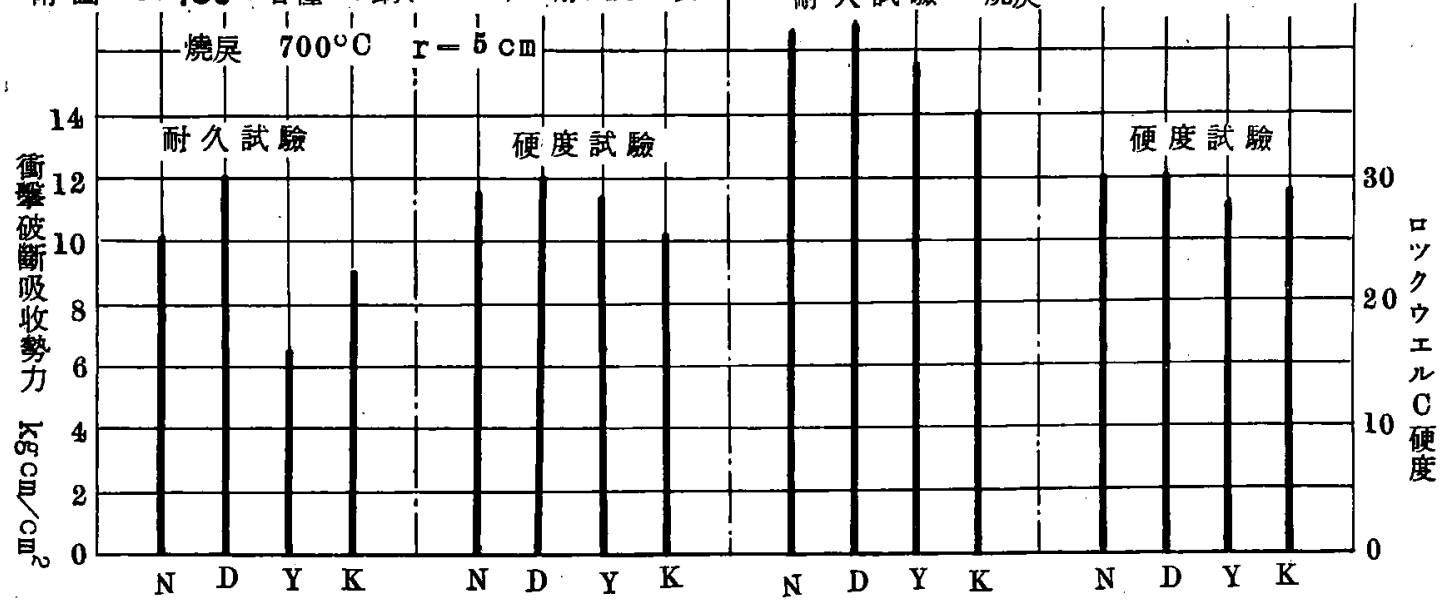

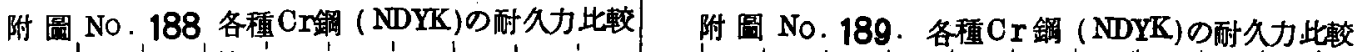

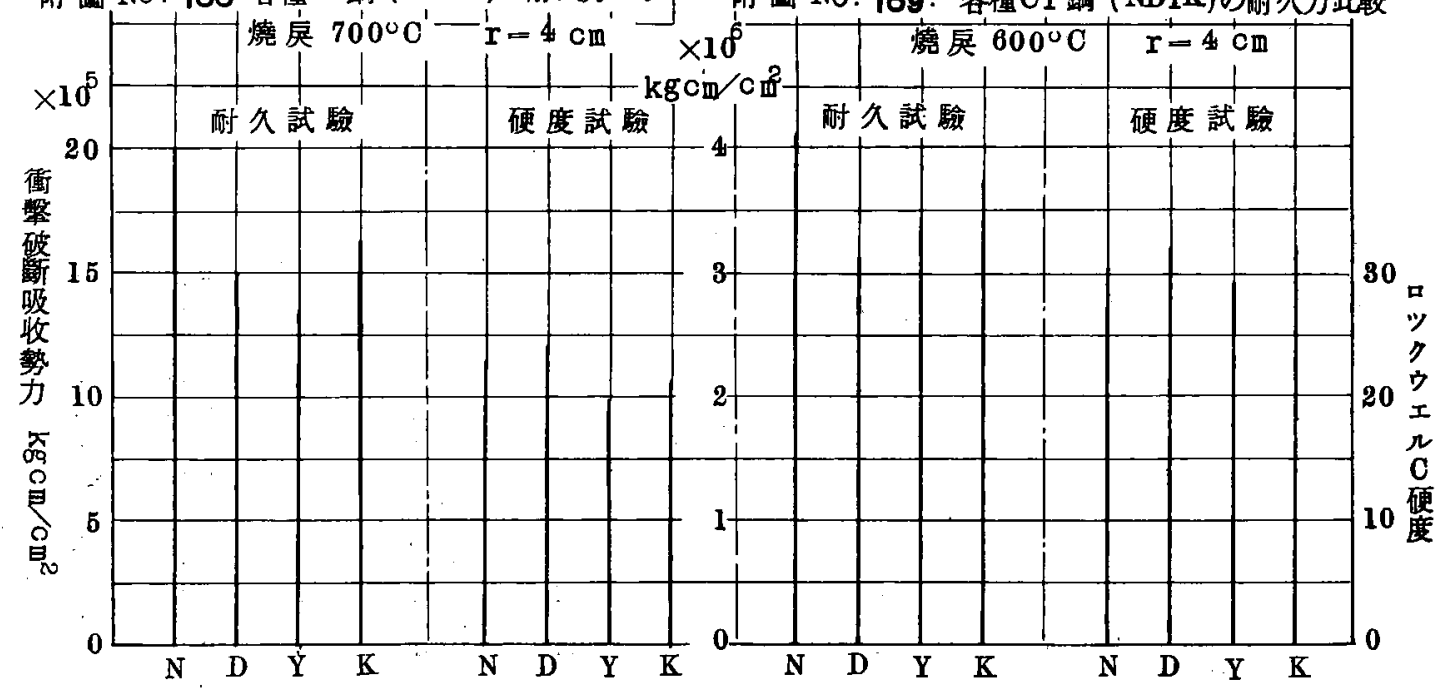

この成績の比校を明にする黨附圖 No. 186 乃 至 No. 191 亿破斷迄の活量 $(\mathrm{E} \times \mathrm{N}) / \mathrm{A}$ と使用し

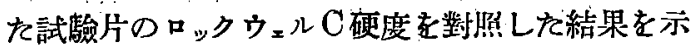
した。この結果を通筧してN 銓は耐久性大で $\mathrm{Y}$ 銅仿比較的劣うてねる。之等何れも同一成分であ つて斯方差を生じてねる原因注不明であるが成分 の上から云二ば、Y 鋼のみは比较的 $C$ 量低く $C r$
量多く、鋼滓及橉の僅に多い事等に基因するので 汢あるまいか。

破断の景況:一燒戻溫度に上つて破断の景浓を 異にしてるるが. $700^{\circ} \mathrm{C}$ 燒㞔の場合には破断の際 沉離れる事少く、之以下の場合には離れ方事が多 的。艘裂は概ね中央桘打部に起 D其中心几生方る 事が多レが、䄳の幅の兩端には加工の第に出來る 

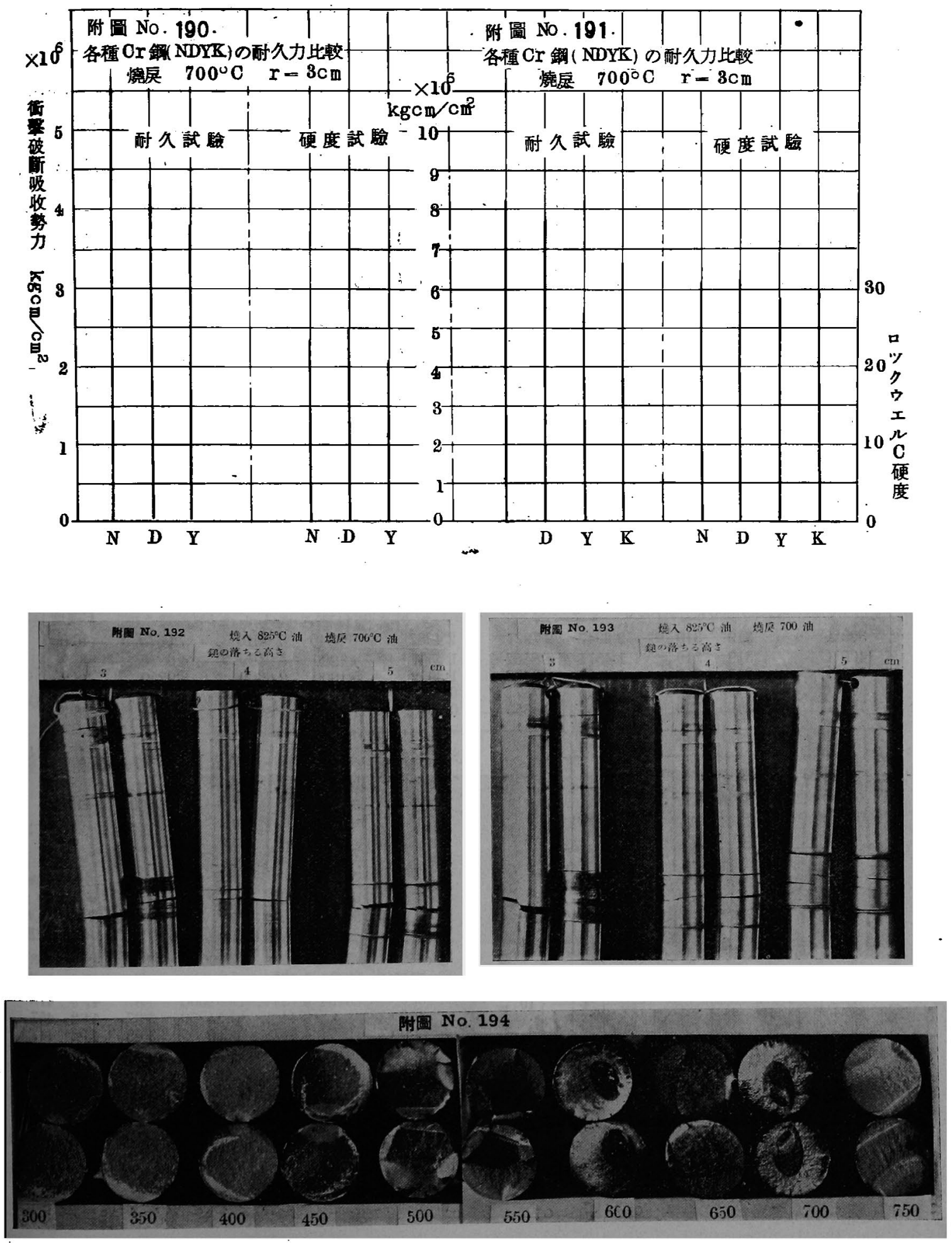
凸部を起點として艎裂を惹起するてともある。之 等の景況は附圆 No.192 (N) 及 No.193(Y)に 示してある。

燒戻溫度別に破斷面の景況は附圖 No.194(D) に示してある。本鋼恃燒杘 $550^{\circ} \mathrm{C}$ 乃至 $700^{\circ} \mathrm{C}$ 迄破斷の䉆に離机强いて引離した斷面を示し てある。破斷機楧に就いては後述する。

(e) $\mathrm{Ni}-\mathrm{Cr}$ 鋼 $(100 \mathrm{~kg} \mathrm{Ni}-\mathrm{Cr}$ 鋼) の燒戻溫度 による影響。

本鋼の成分は次に示す通りである。

$\begin{array}{lllllllll}C & \text { Si } & M n & P & S & N i & C r & W & M o\end{array}$ $\begin{array}{lllllllll}0.29 & 0.18 & 0.38 & 0.018 & 0.011 & 3.22 & 1.29 & 0.37 & 0.42\end{array}$ 熱處理は次の通りである。但しローラーの $\mathrm{r}$ は $5 \mathrm{~cm}$ とした。

燒入 $830^{\circ} \mathrm{C}$ 燒戻 $300^{\circ} \mathrm{C}$ 乃至 $750^{\circ} \mathrm{C}$
この關係を曲線に示す時は附圖 No. 195 亿示 す通り破断回數は大體硬度に比例し衝䗌值に反比 例してるる。但し $750^{\circ} \mathrm{C}$ 燒戻で柱硬度る衝撃值 も共に低く且耐久性る少く脆性大である。

台參考の雹燒戻 $750^{\circ} \mathrm{C}(2)$ の試驗片では破斷 回數より約 5,000包以前に表面に鵃裂を生じを事 を知る。郎ち盘裂發生後は斯の如き脆性狀態では 速に破㫁するるのと思はれる。

(f) $\mathrm{Ni}-\mathrm{Cr}-\mathrm{Mo}$ 鋼

本鋼の成分は次の通りである。（佛國 Jacob Halzer 會社製)

$\begin{array}{cccccccc}C & S i & M n & P & S & N i & C r & M o \\ 0.28 & 0.21 & 0.12 & 0.014 & 0.021 & 2.83 & 3.13 & 0.42\end{array}$
試驗片は燒入 (溫度 $850^{\circ} \mathrm{C}$ 室中) の後燒杘 750 ${ }^{\circ} \mathrm{C}$ 迄とした。

\begin{tabular}{|c|c|c|c|c|c|c|c|c|c|}
\hline \multirow{2}{*}{$\begin{array}{c}\text { 㷪戻偲度 } \\
300^{\circ} \mathrm{C}\end{array}$} & \multicolumn{2}{|c|}{$\begin{array}{l}1 \text { 分間の } \\
\text { 间 霜 數 }\end{array}$} & \multicolumn{2}{|c|}{$\begin{array}{l}\text { 破断包数 } \\
N\left(\times 10^{5}\right)\end{array}$} & \multirow{2}{*}{$\begin{array}{l}\text { 同 平 均 } \\
244987\end{array}$} & \multicolumn{2}{|c|}{$\frac{\mathbf{E} \times \mathbf{N}}{\mathrm{A}}\left(\times 10^{6}\right)$} & \multirow{2}{*}{$\begin{array}{c}\text { 同 平 均 } \\
7 \cdot 0675\end{array}$} & \multirow{2}{*}{$\begin{array}{c}\text { ロック } \\
\text { ウェル } \\
\text { C硬度 } \\
46.0\end{array}$} \\
\hline & 319 & 319 & $2 \cdot 2047$ & 27927 & & 6.2340 & $7 \cdot 9010$ & & \\
\hline $\begin{array}{l}400^{\circ} \mathrm{C} \\
500^{\circ} \mathrm{C} \\
600^{\circ} \mathrm{C} \\
750^{\circ} \mathrm{C}\end{array}$ & $\begin{array}{l}319 \\
317 \\
319 \\
319\end{array}$ & $\begin{array}{l}319 \\
319 \\
319 \\
320\end{array}$ & $\begin{array}{l}1.4571 \\
1.8582 \\
0.8698 \\
0.5337\end{array}$ & $\begin{array}{l}1 \cdot 8562 \\
0.9402 \\
0.7871 \\
0.6853\end{array}$ & $\begin{array}{l}1 \cdot 6567 \\
1 \cdot 3992 \\
0.8285 \\
0.6090\end{array}$ & $\begin{array}{l}4 \cdot 1220 \\
5 \cdot 1900 \\
2 \cdot 4600 \\
1 \cdot 5100\end{array}$ & $\begin{array}{l}5 \cdot 2500 \\
2 \cdot 6600 \\
2 \cdot 2240 \\
1 \cdot 9400\end{array}$ & $\begin{array}{l}4 \cdot 6870 \\
3 \cdot 9250 \\
2 \cdot 3420 \\
1 \cdot 7250\end{array}$ & $\begin{array}{l}40: 2 \\
38 \cdot 2 \\
.30 \cdot 8 \\
28 \cdot 7\end{array}$ \\
\hline
\end{tabular}

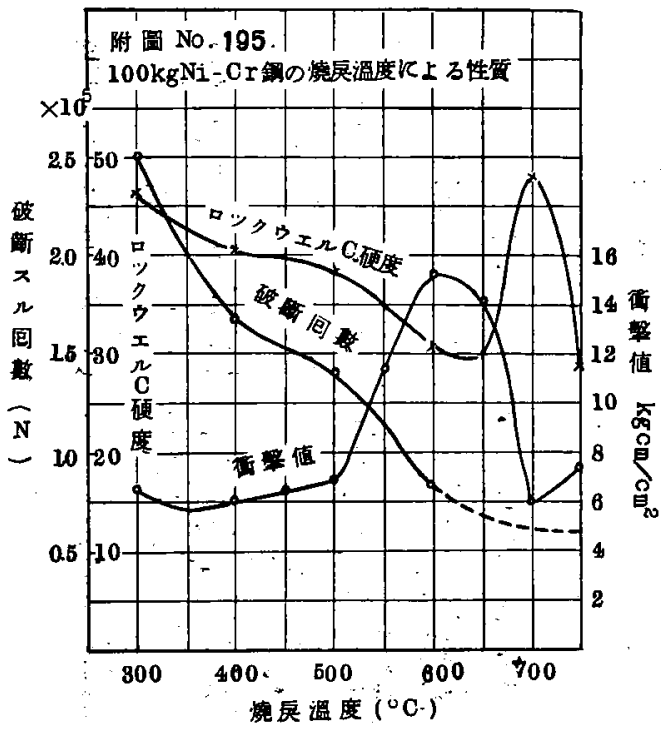

Amsler Hammar Machine による破斷国數 と其他の金筫性能との關係は次の通りである。 $(\mathrm{r}=5 \mathrm{~cm})$

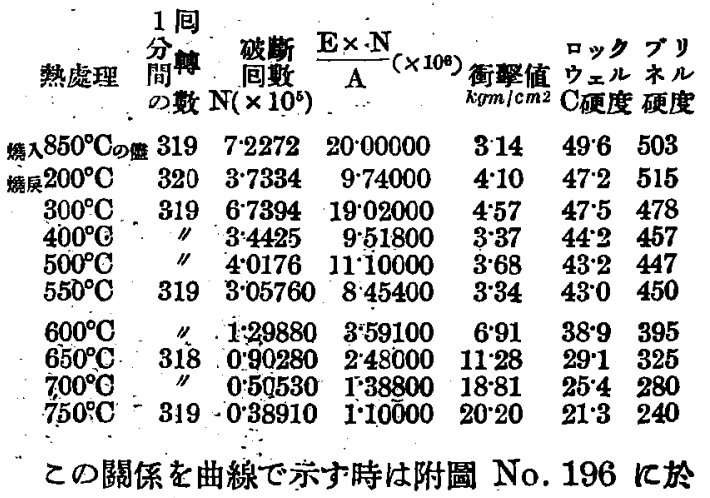
ける様に燒戻溫度の高まると共に硬度は低下レ 


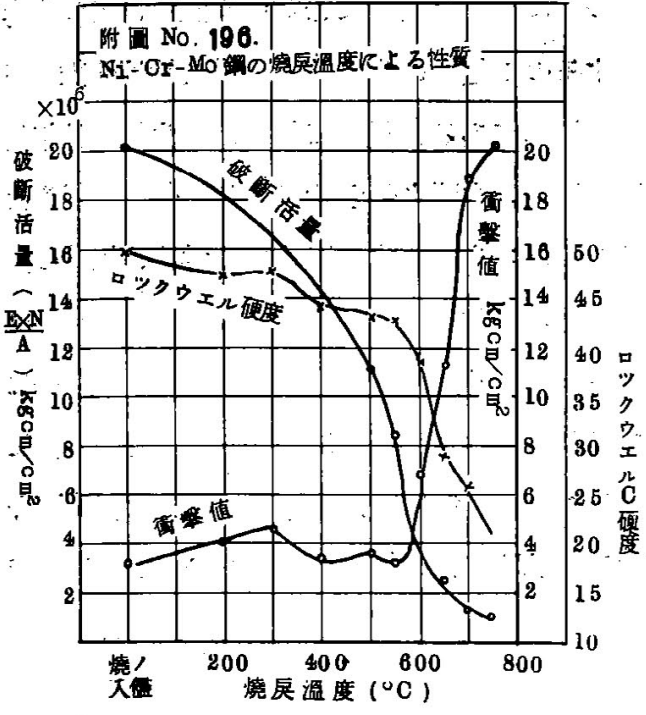

$550^{\circ} \mathrm{C}$ 以上では其降下程度が急である。之と同樣

K Hammer Machine による耐久力は之に殆 んど本行し $500^{\circ} \mathrm{C}$ 以上では急浲下寸る。乙と 反對に衝撃值は $550^{\circ} \mathrm{C}$ 迄は大差なく之以上で急

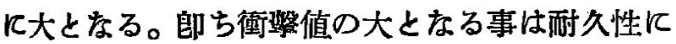
そしい事は明であつて工作上铂せば、使用上は $500^{\circ} \mathrm{C}$ 250 $00^{\circ} \mathrm{C}$ 附近で處理する方が良い筈である。

附圆 197(a)

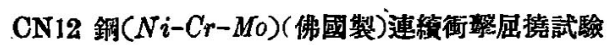

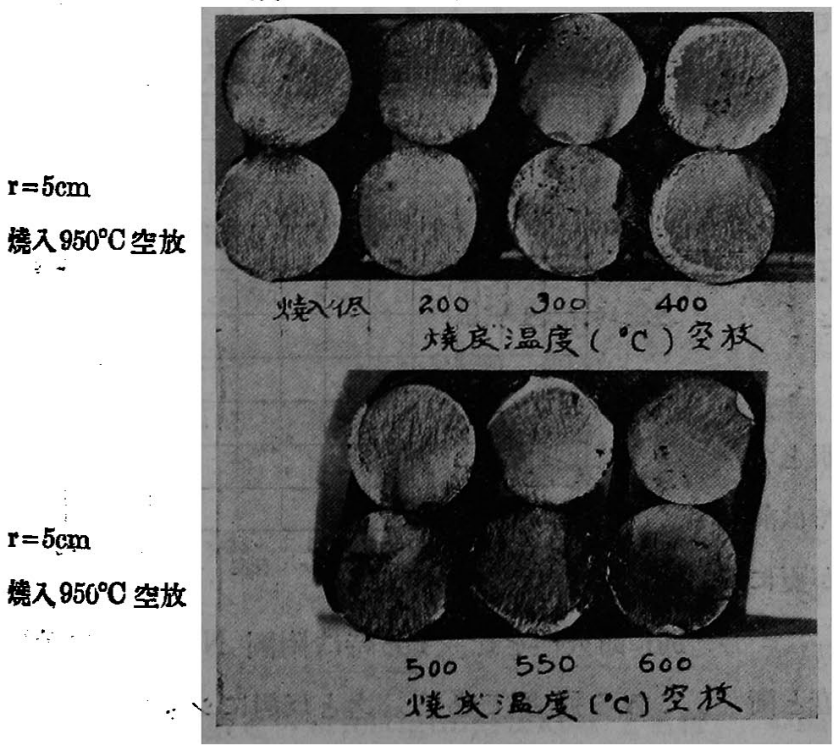

破斷の景況，燒入の㥺のもつと $600^{\circ} \mathrm{C}$ 迄の燒 杘狀態のものは破斷に際しては附圆 No.197 a.b に示す樣に逐次表面に政裂を生じて離れるに反し $\tau 650^{\circ} \mathrm{C}$ 乃至 $750^{\circ} \mathrm{C}$ 燒杘の多のは離狆ない。 (g) $N i-C r-W$ 鋼 (BMW 曲軸銅乙)

本鋼の成分汢次の通りである。

$\begin{array}{lllllllll}C & S i & M n & -P & S & N i & C r & W\end{array}$ 0.21. $0.20 \quad 0.38 \cdot 0 \cdot 010 \quad 0.019 \cdot 4 \cdot 11 \quad 1 \cdot 71 \cdot 0.61$

燒入溫度 $850^{\circ} \mathrm{C}$ (空中放冾)の後燒戻を行ふ。 其溫度は $500^{\circ} \mathrm{C}$ 乃至 $700^{\circ} \mathrm{C}$ とした。前同樣に 破斷回數と其他の金筫性能の關係は次の通りであ 亏。但, $\mathrm{r}=5 \mathrm{~cm}$

\begin{tabular}{|c|c|c|c|c|c|c|}
\hline 熱處理 & 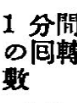 & $\begin{array}{l}\text { 破断国数 } \\
N\left(\times 10^{5}\right)\end{array}$ & $\frac{E \times N}{\left(\times 10^{3}\right)}$ & $\begin{array}{c}\text { 同 } \\
\text { 平均 }\end{array}$ & 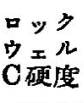 & $\begin{array}{l}\text { 衞慗值 } \\
\mathrm{kgm} / \mathrm{cm}^{2}\end{array}$ \\
\hline 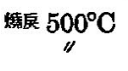 & 320 & $\begin{array}{l}1.6904 \\
1.1584\end{array}$ & $\left.\begin{array}{l}4.690 \\
3.220\end{array}\right\}$ & & $\left.\begin{array}{l}\mathbf{3 4} \cdot \mathbf{4} \\
\mathbf{3 3} \cdot 0\end{array}\right\}$ & $8: 67$ \\
\hline $550^{\circ} \mathrm{C}$ & " & $\begin{array}{l}0.5350 \\
1.4432\end{array}$ & $\left.\begin{array}{l}1.500 \\
4.050\end{array}\right\}$ & 780 & $\left.\begin{array}{l}33 \cdot 6 \\
\mathbf{3 4} \cdot 4\end{array}\right\}$ & $10 \cdot 14$ \\
\hline $600^{\circ} \mathrm{C}$ & $"$ & $\begin{array}{l}09518 \\
07643\end{array}$ & $\left.\begin{array}{l}2 \cdot 665 \\
2 \cdot 145\end{array}\right\}$ & $2 \cdot 405$ & $\left.\begin{array}{l}30 \cdot 9 \\
31 \cdot 3\end{array}\right\}$ & 16.30 \\
\hline
\end{tabular}

附国 197 (b)

$\mathrm{CN} 12$ 銅 $(\mathrm{Ni}-\mathrm{Cr}-\mathrm{Mo})$ (佛國製)

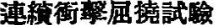

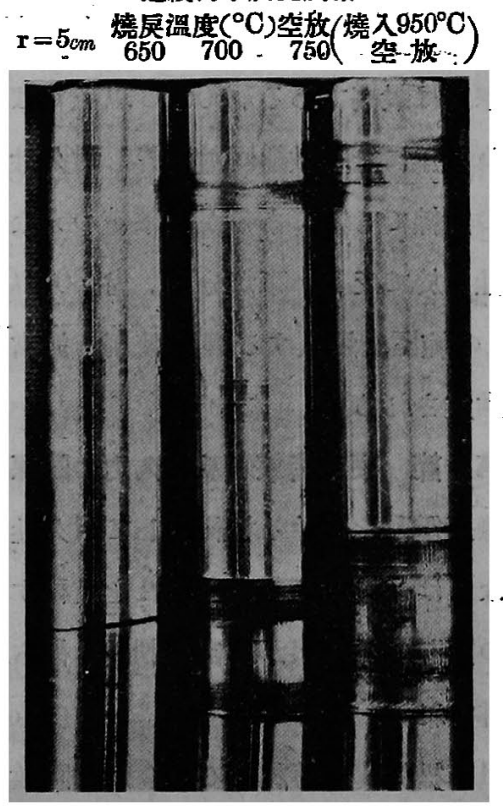




\begin{tabular}{|c|c|c|c|c|c|}
\hline $\begin{array}{l}650^{\circ} \mathrm{C} \\
1 /\end{array}$ & 320 & $\begin{array}{l}06341 \\
0-5404\end{array}$ & $\left.\begin{array}{l}1.780 \\
1.527\end{array}\right\}$ & 1.654 & $\left.\begin{array}{l}25 \cdot 6 \\
254\end{array}\right\} 19 \cdot 30$ \\
\hline$\stackrel{700^{\circ} \mathrm{C}}{\prime \prime}$ & $"$ & $\begin{array}{l}0.5260 \\
04545\end{array}$ & $\left.\begin{array}{l}1 \cdot 477 \\
1 \cdot 277\end{array}\right\}$ & $1: 377$ & $\left.\begin{array}{l}29 \cdot 1 \\
31 \cdot 1\end{array}\right\} 12 \cdot 00$ \\
\hline${ }^{75} 0^{\circ} \mathrm{C}$ & "" & $\begin{array}{l}1.3065 \\
0.6783\end{array}$ & $\left.\begin{array}{l}3.710 \\
1.960\end{array}\right\}$ & 35 & $\left.\begin{array}{l}37 \cdot 3 \\
36 \cdot 8\end{array}\right\} 8.94$ \\
\hline${ }^{800^{\circ} \mathrm{C}}$ & " & $\begin{array}{l}1 \cdot 2605 \\
1 \cdot 5395\end{array}$ & $\left.\begin{array}{l}3 \cdot 545 \\
4: 320\end{array}\right\}$ & & $\left.\begin{array}{l}38 \cdot 1 \\
38 \cdot 6\end{array}\right\} 8 \cdot 31$ \\
\hline${ }^{900^{\circ} \mathrm{C}}$ & "1" & $\begin{array}{l}1.5818 \\
1.5582\end{array}$ & $\left.\begin{array}{l}4: 400 \\
4: 365\end{array}\right\}$ & & $\begin{array}{l}37 \cdot 3 \\
367\end{array}$ \\
\hline
\end{tabular}

この關係は附圖 No. 198 亿示す通り $700^{-} \mathrm{C}$ で 最低破斷包數にあり乍ら硬度は $650^{\circ} \mathrm{C}$ で最低で

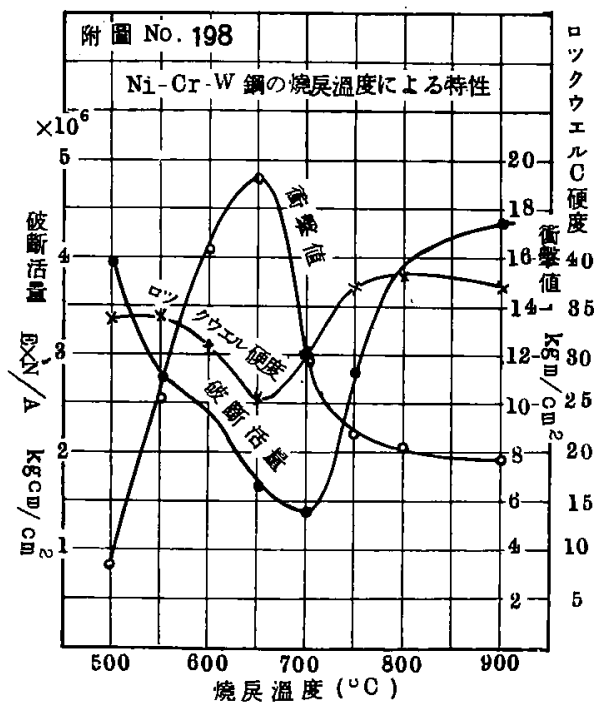

衝整值は最高である。700 $\mathrm{C}$ 以上では空中で燒大 される第に急に破断回數上昇し耐久性大となる。 ての曲線でも明であるが衝揧值の大なる點では耐 久性に於て乏し和事が分る。佾 $800^{\circ} \mathrm{C}$ 乃至 900 ${ }^{\circ} \mathrm{C}$ の範圍で燒入する事は使用上適當であるるの と推定される。

\section{第 4 莭 硬度街等值及涌久力の關保}

繰返震動を受ける材料として耐久性を主眼とす るならば硬度及衝慗値の何れを重視すべきやは前 述の諸試驗の絬果から自ら判斷し得られるが更に 約言すれば

(1) 松村式疲勞試驗では全破斷回數は硬度と衝

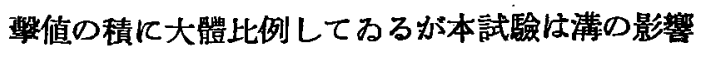

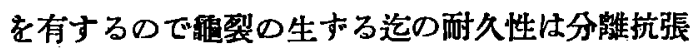
力に比例してるる、從つて雅裂の墢生迄では細粒 脆性の狀態の方耐久性が大である。但洫裂侵入は 靶性の大なるるの」方が深くある篇めに以媵の回 数は多い。

(2) $k$

徒る耐久性は同じく硬度に正比例してるるが更に 明瞭ならしめる弯飞 $\mathrm{Cr}$ 銅、 $\mathrm{Ni}-\mathrm{Cr}$ 鋼、 $\mathrm{Ni}-\mathrm{Cr}$. $M 0$ 鐝及 $N i-C r-W$ 鋼に就てロックゥェル $\mathrm{C}$ 硬度

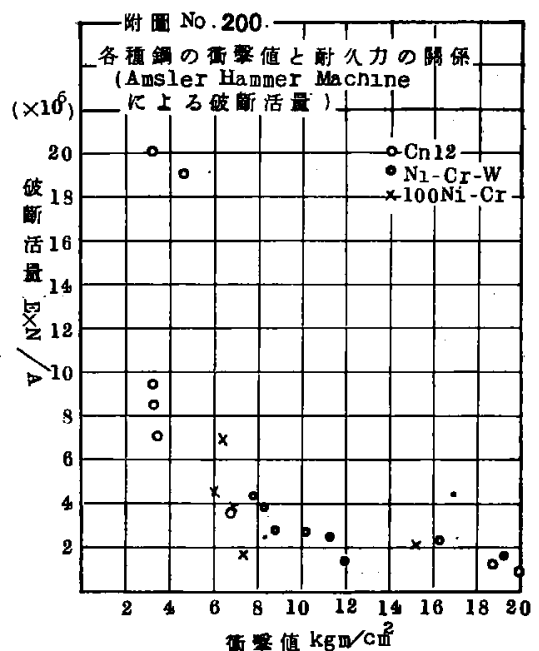

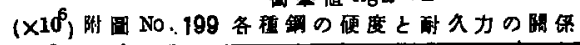

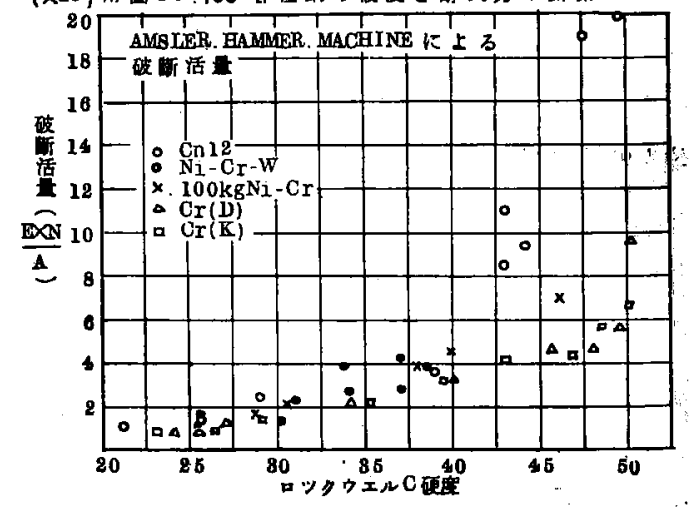

別に耐久性を比较する時は附圖 No. 199 亿示し てある通りである。之と反䍌にシャルピー式政 
繁値を掼軸に之等鋼の耐久性を比较する時は附圖

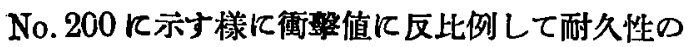
塥堿してるる事が分る。

（3）上記强数鋼の性態を比較するにロックロェル C40 以上で耐久性の著しく高いのは CN 12 鋼 ( $N i-C r-M o$ 鋼) であつて 30 乃至 40 の範圍で は $\mathrm{Ni}-\mathrm{Cr}-\mathrm{W}$ 鈰は比校的秀れてるる。何 $\mathrm{Cr}$ 鋼 は载分之等に比して劣つてるる。

（4）使用上工作上の問題を別にするなら代震動 称久性に重點を置くならば變態㫮以下の細粒脆性 附近の狀態で使用する事は荸支無いわのと思惟さ れる。變態點を越して粗粒脆性を呈する樣な材料 ( $\mathrm{Ni}-\mathrm{Cr}$ 軟鋼の如き) では脆性は恐るべきである か空氣燒入鋼の如きは變態點を越して燒入された 狀態では何等差支ない。

\section{第 5 章 W. Kuntze 氏の Trennfestig- keit の論說に就て}

㯰逸國立材料試驗所報告（Mitteilung aus dem Staatlichen Materialpritfungsamt, 氏 Berlin Dahlem)中に論及せられた W. Kuntze ๑ Berechnung der Schwingungsfestigkeit aus Zngfestigkeit u. Trennfestigkeit 關す る內容の大要に就き拔萃する事とし筆者の說と對 照論議し疲勞計算の基礎に資せん。

氏の論文中、溝付試驗片による所謂分離抗張力 と普通の抗張力から震動に依る抗力を計算する公 式を提出論議しあるるので先づ該抗張力と加工の 程度に應じての變化曲線は附圖 No. 201 に示し てある。同的線の $\mathrm{ST}_{0}$ よ $\mathrm{ST}_{\mathrm{I}}$ の間は直線的に增 大し ST 1 以上に於ては Grain の震燙現像惹 起するものと考人られる。之から $\mathrm{ST}_{\mathrm{II}} / \mathrm{ST}_{0}$ の比 を求めこの係數をVerfestigungsfaktor と名付
ける。ての值は材料の加工凡應ずる良否の境界を 决定し得られるもので、てれから震動疲勞の公式 を誘導した、即ち

$$
\mathrm{S}=\mathrm{S}_{1} \frac{\mathrm{ST}_{\mathrm{II}}}{\mathrm{ST}_{0}}
$$

\section{$\mathrm{S}:$ : 暻際の震動抗力}

$\mathrm{S}_{1}$ : 粘鞂性體の安全震動應力限界

$$
\text { 之から } \mathrm{S}_{1}=\mathrm{S} \frac{\mathrm{ST}_{0}}{\mathrm{ST}_{\mathrm{II}}} \text {. }
$$

を求められる、 $\mathrm{S}_{1}$ は狀點や彈性界には關係なく 抗張力に關係がある。而して別に筫驗的に次の式 から求められる。

$\mathrm{S}_{1}$ は抗張、抗㖘の場合と屈撓の場合に於て 若 干異つてなる。

$$
\begin{aligned}
& \mathrm{S}_{1}=\sigma_{\mathrm{B}}{ }^{\mathrm{n}}-\sigma_{\mathrm{B}} \\
& \text { 抗張 抗壓 震動には } n=1,079 \\
& \text { 属撓震動には } \mathrm{n}=1,074
\end{aligned}
$$

$\therefore S=\left(\sigma_{B}{ }^{n}-\sigma_{B}\right) \frac{S^{S} T_{I I}}{S T_{0}} \cdots \cdots \cdots \cdot(4)$

附圖 No. 202 には各種材料から求めた計算D 值と實際 Sohenck 式疲勞試驗機から求めた結果 の疲勞限界上が一致してるるととを示してるる。 附表には數值的に一致しある事が明記しててある。

以上Wkuntze 氏の論文によつて震動に依る 耐久力は賽驗的に求め少公式から計算によつて求 められる筈なるが份筆者は本諭に敷衍する事とす るならば

（1）公式から求めた S の值は平均應力であつ て局部に集中する考虑を缺いてるる事、郎ち筆者 の論では實際の部品の負荷狀態では局部に大なる 

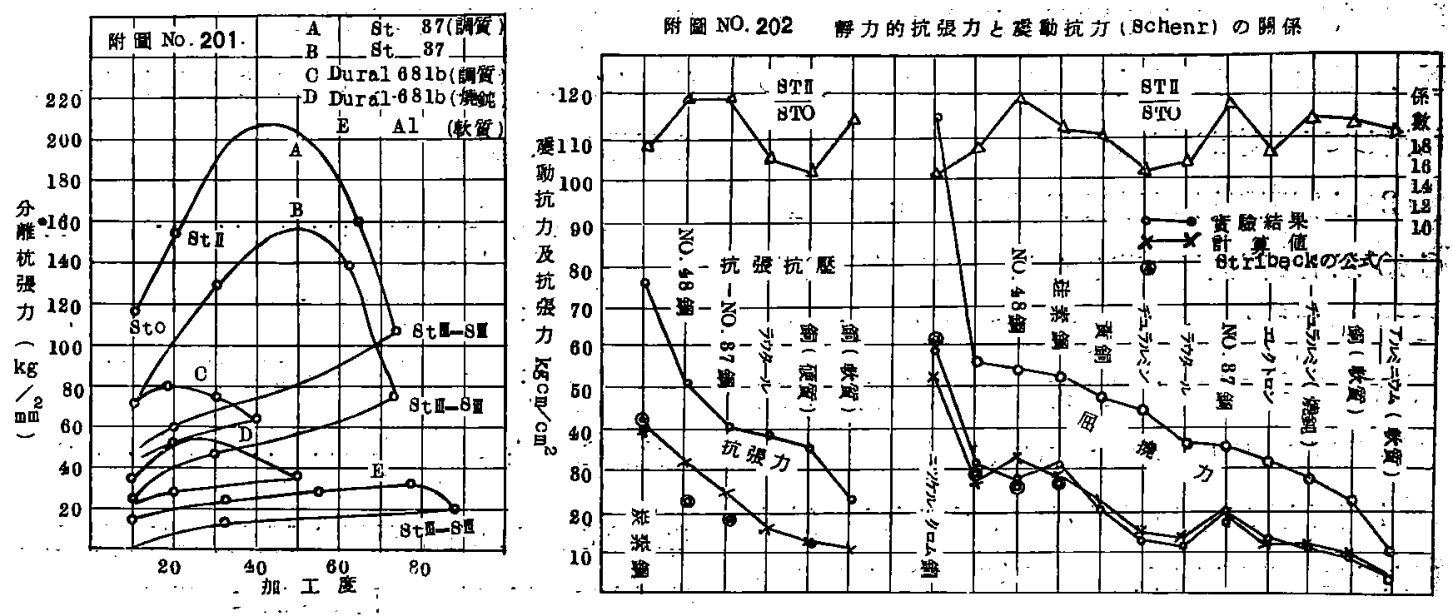

\begin{tabular}{|c|c|c|c|c|c|c|c|c|c|c|c|c|}
\hline & \multirow{3}{*}{ 著 者 名 } & \multicolumn{3}{|c|}{ 震 動 試 驗 } & \multicolumn{4}{|c|}{ 静.力抗張戴驗 } & \multicolumn{4}{|c|}{ ․ 計 . 第 } \\
\hline & & \multirow{2}{*}{$\begin{array}{c}\dot{1} \\
\text { 露憅 } \\
\mathrm{S} \\
\mathrm{s} / \mathrm{mm}^{2}\end{array}$} & \multirow{2}{*}{$\begin{array}{c}\text { 彈性界 } \\
0.003_{\%} \\
\sigma \mathrm{E} \\
\mathrm{kg} / \mathrm{mm}^{2}\end{array}$} & \multirow{2}{*}{$\left|\begin{array}{c}\text { 抗馒力 } \\
\sigma_{\mathrm{B}} \\
\mathrm{kg} / \mathrm{mm}^{2}\end{array}\right|$} & \multicolumn{3}{|c|}{ 分離抗張試驗 } & \multirow[b]{2}{*}{$\begin{array}{l}\text { 抗張力 } \\
k i g / m^{2}\end{array}$} & \multirow{2}{*}{ 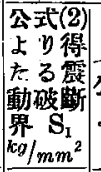 } & \multicolumn{2}{|c|}{ 試驗恒數 } & \multirow{2}{*}{ 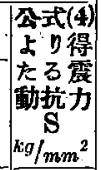 } \\
\hline & & & & & $\left|\begin{array}{c}S \mathrm{~T}_{0} \\
\mathrm{ig} / \mathrm{mm}^{2}\end{array}\right|$ & $\begin{array}{c}\text { STII } \\
\mathrm{kg} / \mathrm{mm}^{2}\end{array}$ & $\frac{\mathrm{ST} \mathrm{TII}_{\mathrm{I}}}{\mathrm{ST}_{\mathbf{0}}}$ & & & $\begin{array}{cc}\text { 公式(4) } \\
\text { L } & \text { (4) } \\
& n \\
\end{array}$ & $\begin{array}{c}\text { 平均 } \\
\mathbf{n}\end{array}$ & \\
\hline 宸素鋮 $(0.7)$ & \multirow{6}{*}{$\begin{array}{l}\text { K. Memmler } \\
\text { u. } \\
\text { K. Laute }\end{array}$} & 407 & $41: 3$ & $74 \cdot 5$ & 126.5 & 164 & $1 \cdot 30$ & $72 \cdot 5$ & $31 \cdot 3$ & 1.081 & \multirow{6}{*}{1.079} & $39 \cdot 4$ \\
\hline 第 48 & & $31 \cdot 2$ & 230 & $49 \cdot 2$ & $87 \cdot 0$ & 155 & $1: 78$ & $49: 5$ & $17 \cdot 5$ & 1.078 & & $31 \cdot 6$ \\
\hline 鍓－第 37 & & $24 \cdot 0$ & 200 & $39 \cdot 5$ & $72 \cdot 0$ & 128 & 178 & 38.0 & $13 \cdot 5$ & 1.079 & & $24: 0$ \\
\hline 5ウタル & & $14 \cdot 7$ & $11 \cdot 5$ & $38 \cdot 0$ & $58 \cdot 0$ & 68 & $1 \cdot 17$ & $39 \cdot 0$ & $12 \cdot 6$ & 1.079 & & $14: 7$ \\
\hline (硬) & & $11 \cdot 8$ & $8 \cdot 6$ & $34: 5$ & 84.5 & 89 & 1.05 & $34 \cdot 9$ & 112 & 1.080 & & $11 \cdot 7$ \\
\hline (軟) & & 9.5 & $2: 0$ & 224 & 440 & 69 & 1.57 & $23 \cdot 7$ & 6.1 & 1.078 & & $9: 7$ \\
\hline ニッヶルクローム鎆 & K. Matthaes & $57 \cdot 0$ & 860 & 114.1 & $227: 0$ & 245 & 1.08 & $114 \cdot 1$ & $52 \cdot 8$ & 1.080 & \multirow{5}{*}{-} & 52.0 \\
\hline 錹第 37 (調留) & \multirow{3}{*}{ P. Ludwik } & 31.0 & $29 \cdot 8$ & $55 \cdot 7$ & 117.0 & 154 & 1.32 & $54: 2$ & $23 \cdot 5$ & 1.087 & & $25 \cdot 8$ \\
\hline 第 48 & & $27 \cdot 0$ & $34: 8$ & $53 \cdot 9$ & 870. & 155 & 178 & $49: 6$ & $15 \cdot 2$ & 1.061 & & 33:3 \\
\hline 珪，素 & & $31 \cdot 0$. & $33: 0$. & $52 \cdot 4$ & 98.0 & 150 & 1.53 & 500 & $20 \cdot 3$ & 1.082 & & $27 \cdot 4$ \\
\hline$\alpha+\beta$ 一黄 銅 & R R. Moore & 20.4 & $(7 \cdot 2)$ & $46 \cdot 4$ & 550 & 80 & 145 & 43.8 & 141 & 1069 & & $22 \cdot 5^{\circ}$ \\
\hline \multirow{2}{*}{$\begin{array}{c}\text { デラルミン } \\
681 \mathrm{~b} \\
(\text { (棓) 質) }\end{array}$} & \multirow{2}{*}{$\begin{array}{l}\text { R. Wagner } \\
\text { P. Ludwik - } \\
\text { D. V. I. } \\
\text { 平 均 }\end{array}$} & $\begin{array}{l}120 \\
140 \\
140 \\
\end{array}$ & $18 \cdot 5$ & $\begin{array}{l}47 \cdot 5 \\
40.8 \\
42 \cdot 4 \\
\end{array}$ & & & & & , & & \multirow{5}{*}{$\begin{array}{l} \\
1.074 \\
\end{array}$} & $\cdots$ \\
\hline & & $13 \cdot 3$ & & 436 & $72 \cdot 5$ & 80 & $1 \cdot 10$ & $46 \cdot 3$ & $12 \cdot 1$ & 1066 & & $15 * 6:$ \\
\hline \multirow[t]{2}{*}{ ラ ウ } & \multirow{2}{*}{ 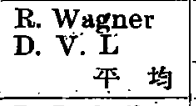 } & $\begin{array}{r}10.0 \\
-134 \\
\end{array}$ & & $\begin{array}{l}32.5 \\
37.6 \\
\end{array}$ & \multirow[b]{2}{*}{58.0} & \multirow[b]{2}{*}{68} & \multirow[b]{2}{*}{$1 \cdot 17$} & \multirow{2}{*}{$39 \cdot 0$} & \multirow[b]{2}{*}{100} & \multirow[b]{2}{*}{1.070} & & \multirow[b]{2}{*}{$12 \cdot 6$} \\
\hline & & 117 & .11 .5 & $35: 1$ & & & & & & & & \\
\hline 第 37 & P. Ludwik & $19^{\circ} 0$ & $22 \cdot 6$ & $35 \cdot 0$ & $72: 0$ & 128 & 178 & 38.0 & $10 \cdot 7$ & 1.074 & & 190 \\
\hline \multirow[t]{2}{*}{$\begin{array}{l}\text { エレタトロン } \\
\text { A.Z.M. }\end{array}$} & $\begin{array}{l}\text { I. G. Farben } \\
\text { P. Lndwik } \\
\text { D. V. L. }\end{array}$ & $\begin{array}{l}13: 0 \\
11.0 \\
15.5 \\
\end{array}$ & $7 \cdot 4$ & $\begin{array}{r}28 \sim 32 \\
31 \cdot 3 \\
33 \cdot 6 \\
\end{array}$ & & $\therefore$ & $\because$ & & $\ldots$ & & & \\
\hline & 平 均 & $13 \cdot 2$ & & 316 & $42 \cdot 0$ & 52 & $1 \cdot 24$ & $33 \cdot 3$ & 106 & 1.083 & & $11 \cdot 5$ \\
\hline Fルミン & $\begin{array}{l}\text { R. Wagner } \\
\text { P. Ludwik }\end{array}$ & $\begin{array}{l}100 \\
120 \\
\end{array}$ & $8 \cdot 1$ & $\begin{array}{r}-260 \\
27.1 \\
\end{array}$ & & & & & & & & \\
\hline 蛅) & 平，均 & 11:0 & $\ldots$ & $26 \cdot 6$ & 33:5 & 53 & 1.58 & 26:0 & $7: 0$ & 1.07 & & $11 \cdot 7$ \\
\hline (软) & $\begin{array}{l}\text { H. F. Moore } \\
\text { U. Jasper } \\
\text { P. Ludwik }\end{array}$ & $\begin{array}{l}7 \cdot 0 \\
7 \cdot 0 \\
\text { g.0 }\end{array}$ & & $\begin{array}{l}22: 8 \\
22 \cdot 4 \\
\end{array}$ & & & & & & & & \\
\hline & ‥平均 & $8: 0$ & 20 & $22 \cdot 6$ & $44: 0$ & 69 & 57 & 237 & 1 & 1065. & & 94 \\
\hline - - (軟) & $\begin{array}{l}\mathbf{K}: \text { Memmler } \\
\mathbf{U}: \mathbf{K} \text {. Lante }\end{array}$ & $3 \cdot 2$ & $(\because 26$ & 9.5 & $18: 0$ & 265 & $1 ; 47$ & $8 \cdot 7$ & $2 \cdot 2$ & $1: 092$ & & 25 \\
\hline
\end{tabular}


分離抗張力が生じて艇裂を發生する事實を注目す b。

（2）材料の理想的使用の見地加ら見れば單に S のみに依つて良否を判斷すべをでは無い，例人ば 宦裂生じて後の破壤の急激でない事や工作上の便 利をも充分考虑に大れねばならない。倘材料自身 の品質上から見てる其他の性筫の良い事を器視し てはなら如。從つて衝盤値や断面收縮率つ様な特 性をも知らなくではらぬ。單に Trennung の みで解決すべきでない。 氏の論文で求められた震動に依 る耐久限界は勿論試驗片について得られた本均應 カである故に實際上の機械部品の局部應力の集中 點に就ての安全性を留意するならば更に其の $1 / 2$ の値を以て安全疲勞限界と認むべきである。

\section{結論}

以上各種特殊鋼に就て疲勞破斷の見地から實驗 しを結果次の㨾な結論を摘錄する事が出來る。

（1）航空機の各程鋼成部分の様索震動的繰返倚 重を受けるものは局部的に過負荷の狀態で疲勞 L 逐に破斷に至る現像を觀察し得られる。先づ常隹 飞於て静力的に局部の變位變形を伴はない所謂分 離抗張力 (Trennfestigkeit) の隹することが知 れる、この值は慣用抗張力に關係を有してるて。 大體鞂性の大きな銓で断面收縮率の 55\% 以上を 有してるる狀態では約 2 倍であつて收縮率の少い るの注約 1.6 倍附近にる、但し疲勞破斷ではて の分離抗張力が變化して一局部から分離破斷を生 おるのである。

（2）實際の部品の疲勞破斷の經路を探究するに 局部負荷狀沅は變形變位を伴はないと言ふ事實は 恰も溝付試驗の際に溝底一定とし外徑を增す時の
極限或は角度を變化した極限の Stress-Strain 曲線の場合 附圖 No. 203 及 No. 204) 飞酷似
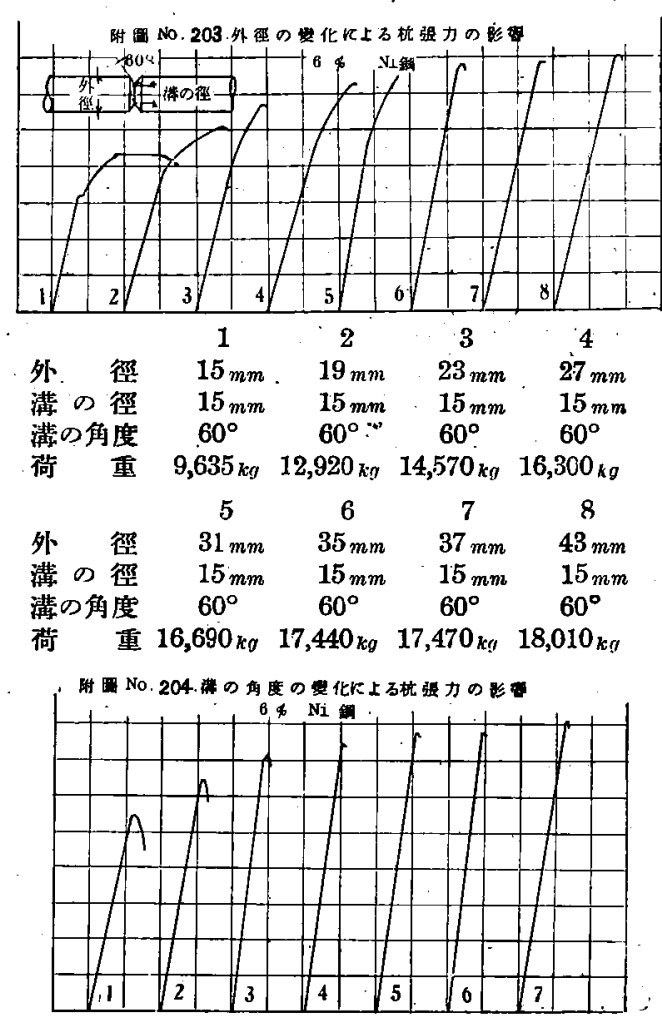

$$
\begin{aligned}
& \text { 外 徑 } \begin{array}{cccc}
1 & 2 & 3 & 4 \\
15_{m m} & 15_{m m} & 15_{m m} & 15_{m m}
\end{array}
\end{aligned}
$$

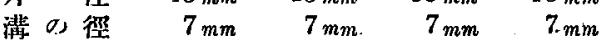

$$
\begin{aligned}
& \text { 清の出罂 } \quad 150^{\circ} \quad 120^{\circ} \quad 30^{\circ} \quad 60^{\circ} \\
& \text { 何 重 } 2,711_{k !} \quad 3,339_{k g} \quad 3,600 k g \quad 3,844 k g \\
& \begin{array}{cccc} 
& 5 & 6 & 7 \\
\text { 外 徑 } & 15 \mathrm{~mm} & 15_{\mathrm{mm}} & 15_{\mathrm{mm}}
\end{array} \\
& \text { 满の唡 } 7 \mathrm{~mm} \quad 7 \mathrm{~mm} \quad 7 \mathrm{~mm} \\
& \begin{array}{lccc}
\text { 溝の有庋 } & 45^{\circ} & 30^{\circ} & 15^{\circ} \\
\text { 菏 } & 3910^{\circ} & 3969^{\prime} & 4,063
\end{array}
\end{aligned}
$$

し恰も彈性的變形を煘す狀態に在るるのと推察さ れる。故に部品の强度設計上には炕棒や板材試驗 片に依る抗張試驗の樣な粘性變形を阻止し寗ろ普 通抗張力の 2 倍附近の荷重にる耐えると言ふ事に なる、俳し繰返荷重の進行と共に分離抗張力及低 下する譯である。

今一般に使用されておる Beam Theory とし 
ての公式

$$
\mathrm{f}=\frac{\mathrm{M}}{\mathrm{Z}} \quad \mathrm{Z}=\frac{\mathrm{I}}{\mathrm{y}}
$$

但 $\mathrm{f}=$ 抗 張 力 $\mathrm{M}=$ 屈撓モーメント $Z=$ 断面係數 $I=$ 慣性モーメント $\mathrm{y}=$ 中心からの距離

に於て論するならば $\mathrm{f} は$ は彈性限界以队で成立する 譯で從來の丸棒や板材から求めた試驗片の抗張力 と見做すととは不合理である。何となれば之等は 粘性變形を伴ふ心的らである。併し本曲線で示す分 離抗張力は直線的に變化する故に抗張力に等しい 值を其儘適用しても不合理ではないてとが分る。

（3）分離破斷の機構上挋裂の誘起は局部に於け る內力傾科供因する事が多い。而して該內力が +ーの方向に絕えす變化し祳動的に局部を驰ませ る。其結果は分離抗張力が低下し容易に分離破断 を招棵す。

（4）衝撃試驗と熱處理との關係を說明し。耐久 力の大ならんてとを鉒むためには衝媻值を低下し てる所謂細粒脆性に屬する場合に汁何等差支へな い。燒入後燒㞔溫度撰定上の指針として變態點附
近の衝盤値の大なる Sorbitic Structure を撰ぶ こよは耐久性にそしい。學ろ Troostite に近く 使用する方がよい。

（5）松村式疲勞試驗上分離破斷機構に就て論じ 洫裂發生は分離抗張力の大なる時が遲い、郎ち耐 久性大であるが衝撃值との關係を考察するに其值 の大なるるのは㛹裂發生後其侵入度大であつて所 謂 Silky Structure 呈する。但細粒脆性のも のは耐久力大であるにも拘らす、粗粒脆性のもの は之に反す。

(6) Amsler Universal Hammer Machine による耐久力と硬度並に衝毒値の關係を攻究する に硬度の大なるるの」方が耐久性大である。又硬 度同一であつて衝盤值の大なるるのは安全である と考へられる。

（7）W. Kuntze 氏の提出 した疲勞限界の公 式 $\mathrm{S}=\left(\sigma_{\mathrm{B}}{ }^{\mathrm{n}}-\sigma_{\mathrm{B}}\right) \mathrm{ST}_{\mathrm{II}} / \mathrm{ST}_{0}$ の更に $1 / 2$ を探つて 安全疲勞限界とするならば實際の部品局部の設計 として相當信賴し得るるのと思はれる。 